\title{
3. EASTERN INDIAN OCEAN CRETACEOUS AND PALEOGENE QUANTITATIVE BIOSTRATIGRAPHY ${ }^{1}$
}

\author{
A.J.M. van Eijden ${ }^{2}$ and J. Smit ${ }^{2}$
}

\begin{abstract}
During ODP Leg 121 holes were drilled at seven sites, on a transect across Broken Ridge and along Ninetyeast Ridge.

The four Broken Ridge sites recovered a Turonian to Holocene composite section, recording its environmental and tectonic history. The three Ninetyeast Ridge sites sampled a Late Cretaceous to Tertiary paleoenvironmental transect and a record of hot-spot volcanism.

$\mathrm{CaCO}_{3}$ content, weight percent $>40-\mu \mathrm{m}$ residue content, and weight distribution of the size fractions were recorded for all samples from all sites. Species distribution was determined quantitatively for two fractions. The number of $>125-\mu \mathrm{m}$ planktonic foraminifers per gram dry sediment and the percentage of $>250-\mu \mathrm{m}$ planktonic foraminifers of the $>125-\mu \mathrm{m}$ fauna were calculated, which provides a powerful means to study the paleoenvironment, as it gives information on size distribution, productivity, bottom currents, and dissolution.

The description of Morozovella variospira (Belford, 1984) is emended, based on observations of material from middle
\end{abstract} Paleocene sediments from Site 758 on northern Ninetyeast Ridge.

\section{INTRODUCTION}

The scientific objectives of Ocean Drilling Program (ODP) Leg 121 were threefold: first, to obtain data on the breakup of the Broken Ridge-Kerguelen Plateau in order to test varying hypotheses of passive margin formation; second, to recover a record of the Tertiary paleoceanography of the southeastern Indian Ocean; and third, to sample the history of the Kerguelen hot spot.

Broken Ridge and the Kerguelen-Heard Plateau formed as an oceanic platform from basaltic intraplate volcanism in the Early Cretaceous (Morgan, 1981). Broken Ridge was separated from the Kerguelen Plateau at about anomaly 18 time (about $42 \mathrm{Ma}$ ) (Berggren et al., 1985; Mutter and Cande, 1983). After the breakup, Kerguelen Plateau remained more or less stationary, while Broken Ridge moved northward with the Australian plate to its present position at about $30^{\circ} \mathrm{S}$ (Fig. 1) and was uplifted isostatically, tilting the existing Cenomanian-middle Eocene deposits, which were partially eroded (Davies, Luyendyk, et al., 1974). The tilted beds are discordantly overlain by subhorizontal late Eocene and younger deposits. Sites 752 to 755 were drilled on a transect across Broken Ridge (Figs. 2 and 3 and Table 1), providing a composite section of Turonian to Pleistocene age. Postrift oozes and chalks are winnowed and some hiatuses are present in upper Eocene and iower Oligocene deposits (as also recorded by Kennett, 1982; Keller, 1983). This has been interpreted as the result of the separation of Australia from Antarctica, causing cooling of Antarctica (Kennett, 1982) and thereby increasing the activity of bottom currents. These currents would have been more intense over the shallow sill formed by Ninetyeast Ridge and Broken Ridge.

Very little material from directly above the unconformity could be recovered, as it consists of loose gravels and other shallow-water deposits. At Site 753 the youngest material from

\footnotetext{
'Weissel, J., Peirce, J., Taylor, E., Alt, J., et al., 1991. Proc. ODP, Sci. Results 121: College Station, TX (Ocean Drilling Program).

${ }^{2}$ Geomarine Center, Institute for Earth Sciences, Free University, P.O. Box 7161, 1007 MC Amsterdam, The Netherlands.
}

below the unconformity was recovered, but overlap with Site 752 was not established. Drilling had to be terminated in middle Eocene limestones. Site 755 drilled the oldest sedimentary rocks but failed to reach the prominent basement reflector. Prerift material consists of chalks to limestones with intercalated chert and the amount of volcanic ash increases downcore.

Ninetyeast Ridge formed when the Indian plate moved northward over the Kerguelen hot spot (Luyendyk, 1977; Luyendyk and Rennick, 1977). Sites 756 through 758 were drilled along Ninetyeast Ridge (Fig. 2 and Table 1). At Site 756, Quaternary, Neogene, and Oligocene oozes were recovered overlying upper Eocene foraminiferal limestones, which overlie basement basalts. At Site 757 a fairly complete Pleistocene to lower Eocene section was recovered, grading downward into upper Paleocene volcanic ashes. At Site 758 a thick, complete Quaternary, Neogene, and Oligocene section was recovered. The Eocene occurs in one core-catcher sample only, indicating a period of nondeposition and/or erosion. The Paleocene is well preserved and almost complete, only Zones P0, P1a, and part of P1b are missing, as is the top of the Maestrichtian. Downhole in the Cretaceous, the amount of volcanic ash increases and the preservation of foraminifers deteriorates rapidly.

The Cretaceous/Tertiary boundary was cored twice, at Sites 752 and 758 . At Site 758 preservation is excellent, but the lowermost Paleocene and uppermost Cretaceous are missing. Preservation is poor at Site 752 , but sedimentation was continuous across the Cretaceous/Tertiary boundary. The boundary is marked by a 6-m-thick layer of volcanic ashes, which is barren of foraminifers. Lowermost Paleocene faunas are very poorly preserved; the Globigerina eugubina Zone and Guembelitria cretacea Zone (Smit, 1977) were not recognized.

\section{PREVIOUS STUDIES}

Little is known about pre-Neogene planktonic foraminifers from the Indian Ocean. Deep Sea Drilling Project (DSDP) Leg 22 drilled sites in the Wharton Basin and on Ninetyeast Ridge (Berggren et al., 1974; Davies, Luyendyk, et al., 1974; McGowran, 1974; Pessagno and Fouad, 1974). The Paleocene and Eocene were deposited in shallow-water facies at Sites 214, 216, and 217 and in deep-water facies at Sites 213 and 215 . Site 214 probably 


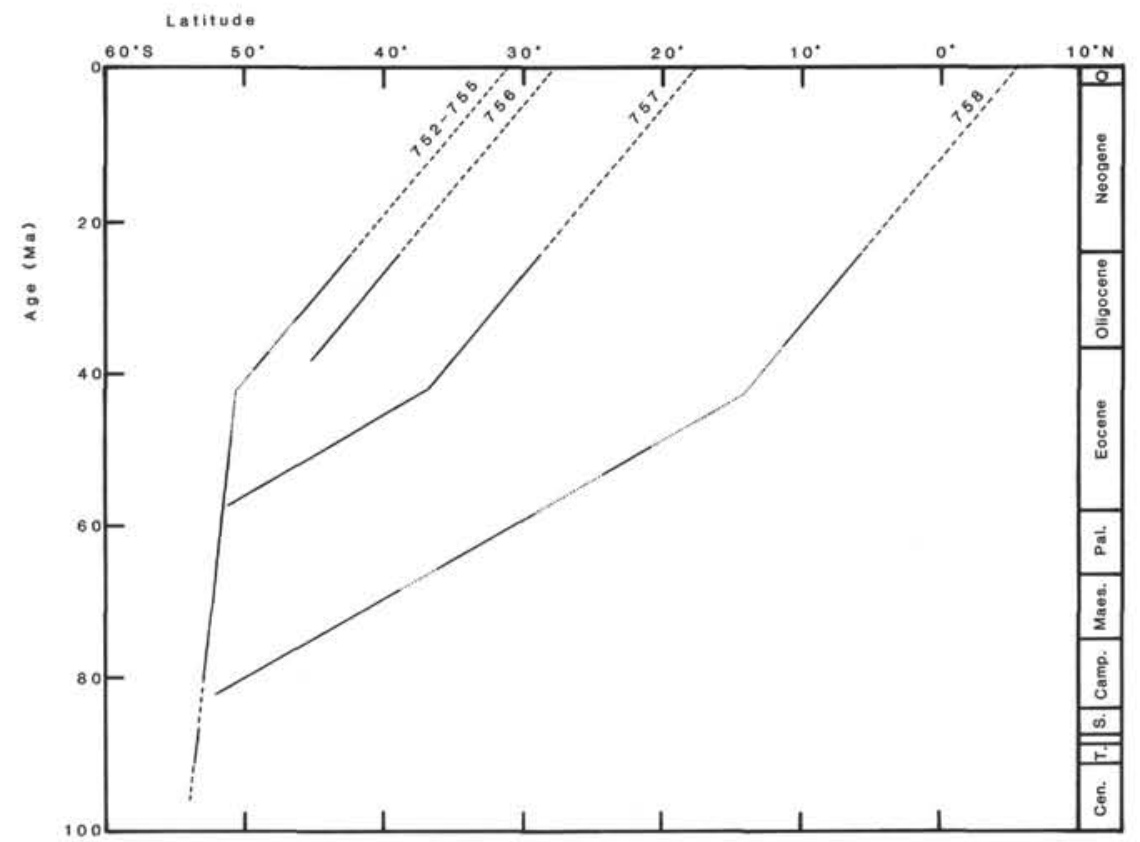

Figure 1. Latitude vs. time diagram of Leg 121 sites. Dotted line $=$ hiatus, dashed line $=$ not drilled or not studied.

contains a continuous section through the Paleogene, unlike the other sites, which show hiatuses. Preservation is generally poor below the Oligocene and zonal markers are rare.

During DSDP Leg 26, sites were drilled in the Wharton Basin and on Broken Ridge (Boltovskoy, 1974; Herb, 1974). In the faunas from Site 255 (Broken Ridge) markers are rare and the zonal schemes of Banner and Blow (1965) and Blow (1969) were found inapplicable. Below a lower Miocene section, Eocene and Santonian material with poorly preserved faunas was recovered.

On DSDP Leg 28 a number of sites were drilled south of Australia, close to Antarctica (Kaneps, 1975; Hayes, Frakes, et al., 1975). The recovered faunas indicate a temperate to subtropical climate from the Oligocene onward. Older faunas are generally very poorly preserved and typical for a cool, austral climate. Only a few species of Catapsydrax, Globigerina, and Chiloguembelina were recognized.

\section{MATERIAL AND METHODS}

A maximum of $50 \%$ of each sample $\left(20 \mathrm{~cm}^{3}\right.$, except corecatcher [CC] samples, which are larger) was dried at $50^{\circ} \mathrm{C}$ for 24 $\mathrm{hr}$, after which a subsample of about $0.5 \mathrm{~g}$ was taken for carbonate content analysis. The remainder was weighed and soaked in tap water. Many samples readily disintegrated, but some ultrasonic cleaning was necessary. The samples were wet-sieved, using $40-\mu \mathrm{m}$ sieve cloth, and dried at $50^{\circ} \mathrm{C}$. The residue was dry-sieved over a set of sieves of 250 and $125 \mu \mathrm{m}$; the fractions were weighed. Many samples, especially those of Cretaceous and Eocene age, contain small pebbles of undisintegrated material, which accumulated in the $>250-\mu \mathrm{m}$ fraction, causing a high weight proportion of $>250-\mu \mathrm{m}$ material and a high residue percentage. The weight percent $<40-\mu \mathrm{m}$ material of well-preserved, carbonate-rich samples indicates the amount of calcareous nannofossils in the sediment and provides a means of determining nannoplankton vs. foraminiferal carbonate production. Comparing the weight percentages of the different fractions $(<40,40-125$, $125-250$, and $>250 \mu \mathrm{m}$ ), combined with the preservation, provides information on the possible winnowing of fine material, dissolution, and different rates of production per size class.
The $>250$ - and $125-250-\mu \mathrm{m}$ fractions were dry split until a workable aliquot remained. This was strewn on a picking tray, and random specimens were identified until 150-200 specimens of each fraction had been counted. As a result of handling and splitting problems, the $40-125-\mu \mathrm{m}$ fraction was not counted, but only scanned for species not present or rarer in the coarser fractions, and relative frequencies were estimated. The distribution and relative frequency of radiolarians, ostracodes, Inoceramus prisms, glauconite, and volcanic ash particles were also recorded.

Planktonic foraminifers were identified using Berggren (1977), Bolli and Saunders (1985), Caron (1985), Jenkins (1966, 1985), Kennett and Srinivasan (1983), Masters (1977), Nederbragt (1989, in press), Pessagno (1967), Postuma (1971), Robaszynski and Caron (1979), Robaszynski et al. (1984), Stainforth et al. (1975), Subbotina (1953), and Toumarkine and Luterbacher (1985).

\section{RESULTS}

\section{General Remarks}

The fauna in the $>250-\mu \mathrm{m}$ fraction usually has few species in common with that in the $125-250-\mu \mathrm{m}$ fraction and commonly contains only a few percent of the total number of specimens present. Many markers and conspicuous species occur only in the $>250-\mu \mathrm{m}$ fraction and thus constitute an insignificant percentage of the total fauna. The overall fauna composition will rarely differ much from that of the $125-250-\mu \mathrm{m}$ fraction (in agreement with Berger, 1971). The counts for both fractions are presented separately.

Benthic/planktonic $(\mathrm{B} / \mathrm{P})$ ratios (expressed as $(\mathrm{B} /(\mathrm{B}+\mathrm{P})) \cdot$ 100 , because benthic foraminifers are usually rarer than planktonic foraminifers) are almost always higher for the $>250-\mu \mathrm{m}$ fraction than for the $125-250-\mu \mathrm{m}$ fraction. This implies that whenever planktonic foraminiferal faunas are studied quantitatively or when $\mathrm{B} / \mathrm{P}$ ratios are determined, it is crucial to state which fraction was studied. $\mathrm{B} / \mathrm{P}$ ratios are partially controlled by sample quality; smooth-walled benthic foraminifers are more 


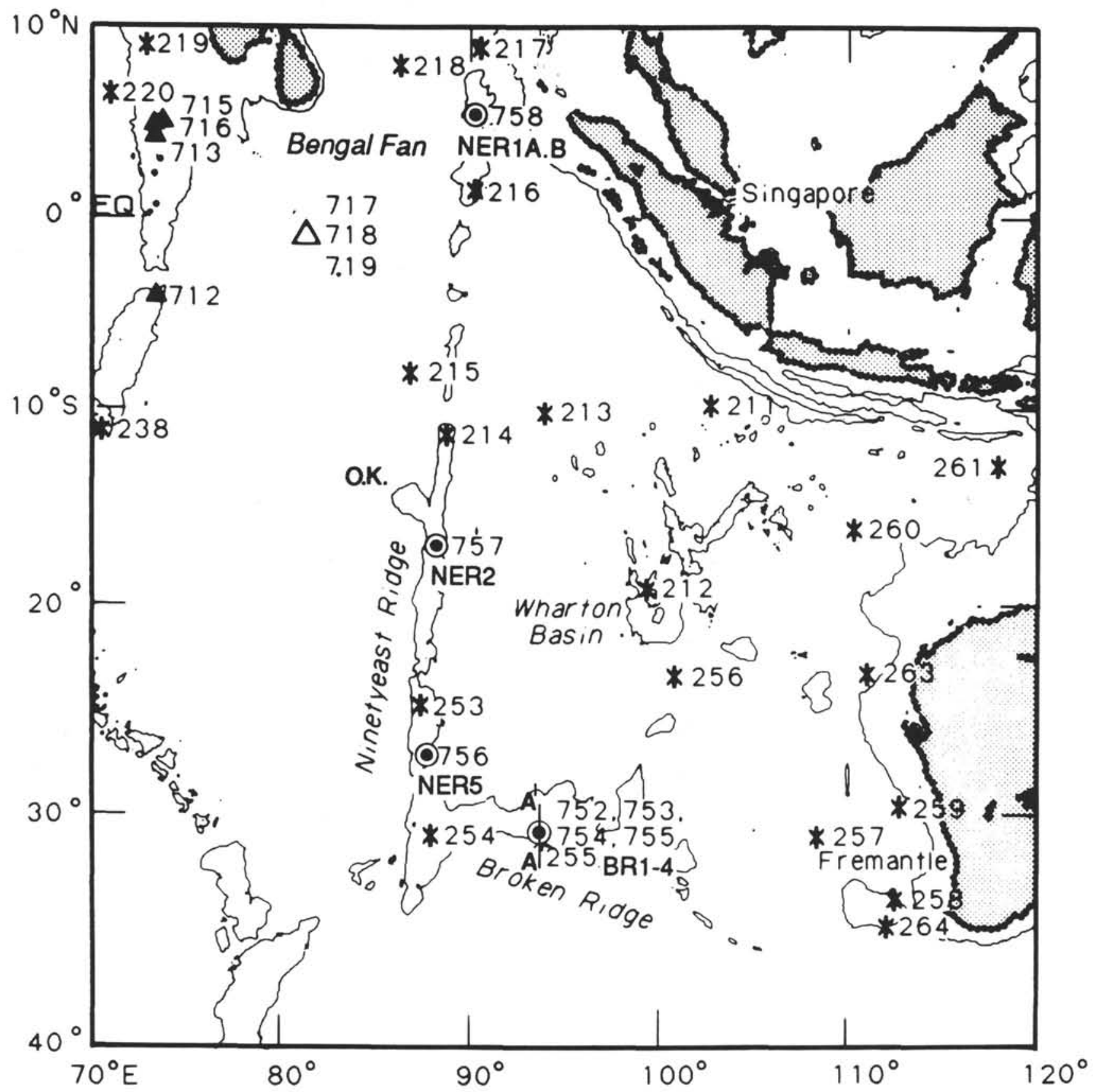

Figure 2. Location map of Leg 121 sites, eastern Indian Ocean.

easily freed from indurated chalks than are rougher walled planktonic foraminifers, causing higher $\mathrm{B} / \mathrm{P}$ ratios in harder sediments.

From the proportion that was examined and the number of planktonic foraminifers present in the $>125-\mu \mathrm{m}$ residue, we calculated the number of $>125-\mu \mathrm{m}$ planktonic foraminifers per gram dry sediment. Knowing the number of specimens in the 125$250-\mu \mathrm{m}$ and $>250-\mu \mathrm{m}$ fraction, the proportion of $>250-\mu \mathrm{m}$ foraminifers of the $>125-\mu \mathrm{m}$ fauna was also calculated. This provides information on productivity, the size distribution of planktonic foraminiferal faunas, and possible dissolution or selective removal of small, delicate foraminifers.

\section{Quantitative Results}

Site 752

Calcium carbonate content at this site fluctuates at about $80 \%$, with two major exceptions (Fig. 4A). One occurs at 90-110 m below seafloor (mbsf) and includes condensed sedimentation with two hiatuses separating the upper Oligocene from the upper Eocene and the upper Eocene from the middle Eocene, respectively. The other, at 350-360 mbsf, corresponds to the Cretaceous/Tertiary boundary. Other, smaller fluctuations are due to varying proportions of volcanic ash. 


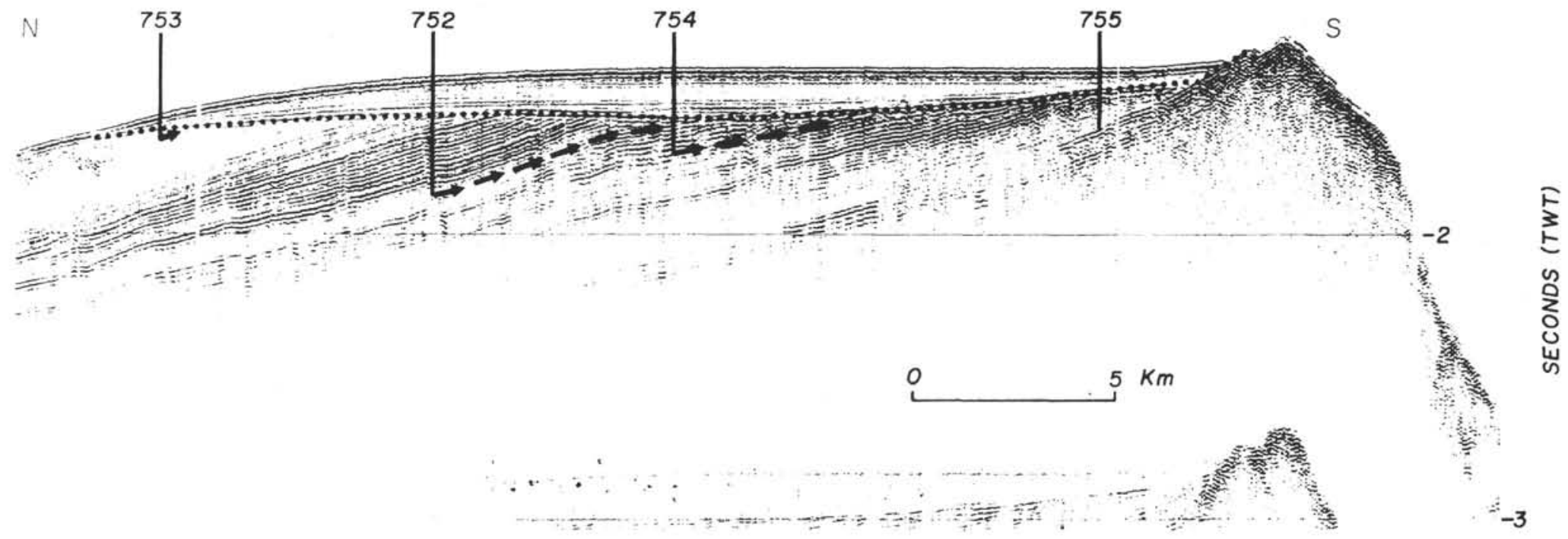

Figure 3. Seismic cross section of Broken Ridge with position (see also Fig. 2), penetration, and correlation of Sites 752-755. 
Table 1. Leg 121 site summaries.

\begin{tabular}{lrrrrrr}
\hline Hole & $\begin{array}{c}\text { Latitude } \\
\text { (degrees) }\end{array}$ & $\begin{array}{c}\text { Longitude } \\
\text { (degrees) }\end{array}$ & $\begin{array}{c}\text { Water } \\
\text { depth } \\
(\mathrm{m})\end{array}$ & $\begin{array}{c}\text { Penetration } \\
(\mathrm{m})\end{array}$ & $\begin{array}{c}\text { Cored } \\
(\mathrm{m})\end{array}$ & $\begin{array}{r}\text { Recovery } \\
(\mathrm{m})\end{array}$ \\
\hline 752A & -30.89120 & 93.57800 & 1086.3 & 317.60 & 317.60 & 217.32 \\
752B & -30.89140 & 93.57750 & 1086.3 & 435.60 & 158.00 & 112.34 \\
753A & -30.83900 & 93.58990 & 1176.1 & 62.80 & 62.80 & 61.06 \\
753B & -30.83850 & 93.58990 & 1176.1 & 100.20 & 48.20 & 0.04 \\
754A & -30.94060 & 93.56650 & 1063.6 & 172.10 & 170.00 & 128.27 \\
754B & -30.94060 & 93.56650 & 1065.5 & 354.70 & 232.00 & 91.85 \\
755A & -31.02980 & 93.54670 & 1057.9 & 208.40 & 178.40 & 80.21 \\
756A & -27.35550 & 87.59680 & 1518.1 & 9.70 & 9.70 & 9.70 \\
756B & -27.35550 & 87.59680 & 1518.1 & 104.30 & 104.30 & 105.70 \\
756C & -27.35420 & 87.59820 & 1515.8 & 159.0 & 76.60 & 61.81 \\
756D & -27.35480 & 87.59740 & 1513.13 & 221.0 & 101.2 & 46.04 \\
757A & -17.02430 & 88.18160 & 1650.2 & 9.40 & 9.40 & 9.40 \\
757B & -17.02430 & 88.18160 & 1652.1 & 374.80 & 374.80 & 271.94 \\
757C & -17.02320 & 88.18020 & 1643.6 & 420.70 & 106.10 & 67.78 \\
758A & 5.38420 & 90.36120 & 2923.6 & 676.80 & 676.80 & 453.83 \\
758B & 5.38400 & 90.36120 & 2925.6 & 96.00 & 96.00 & 98.68 \\
758C & 5.38400 & 90.36110 & 2922.2 & 9.40 & 9.40 & 9.40 \\
\hline
\end{tabular}

The weight percentage $>40-\mu \mathrm{m}$ residue (Fig. $4 \mathrm{~B}$ ) is high down to $110 \mathrm{mbsf}$, suggesting winnowing of the sediments during the late Eocene and Oligocene. For the lower part of the section, values fluctuate but are generally low for the Eocene and Paleocene (110-350 mbsf), increasing somewhat below the Cretaceous/Tertiary boundary. High volcanic ash content causes high values just above the Cretaceous/Tertiary boundary.

Graphing the size distribution by weight (Fig. 4C) shows much $125-250-\mu \mathrm{m}$ material in the Oligocene samples, which is probably due to winnowing. Very little fine material is present from 90 to $110 \mathrm{mbsf}$ (middle Eocene). Because this material was deposited immediately before the period of uplift and erosion this is probably due to dissolution. In contrast, little coarse material generally is present in the lower middle Eocene and Paleocene section (110-350 mbsf). The poor sample quality farther downhole has prevented reliable estimates of the fraction distributions for many samples. Material from just above the Cretaceous/Tertiary boundary consists mostly of fine volcanic ash particles.

The benthic/planktonic ratio for the $125-250-\mu \mathrm{m}$ fraction (Figs. 11A, 12A, and 13A) shows two conspicuous peaks. One, at $90-110 \mathrm{mbsf}$, corresponds to the hiatuses in the middle Eocene to lower Oligocene; the other, at 350-360 mbsf, corresponds to the Cretaceous/Tertiary boundary. Otherwise, ratios are low except for the Cretaceous.

The number of $>125-\mu \mathrm{m}$ planktonic foraminifers per gram sample (Fig. 4D) fluctuates strongly. It is highest in the Oligocene and Paleocene.

Foraminifers $>250 \mu \mathrm{m}$ constitute $1 \%$ to $5 \%$ of the $>125-\mu \mathrm{m}$ fauna for the Oligocene and Eocene and less than $1 \%$ for the Paleocene and Cretaceous, with a single, unexplained exception (Fig. 4E).

The late Oligocene faunas are well preserved. The early Oligocene fauna in Sample 121-752A-10H-CC is poorly preserved and corroded. This sample contains much glauconite. Coral, bryozoan, and echinoderm fragments occur in lower Oligocene Sample $121-752 \mathrm{~A}-11 \mathrm{H}-3,110-115 \mathrm{~cm}$. Sample $121-752 \mathrm{~A}-12 \mathrm{X}-\mathrm{CC}$ is almost barren. Radiolarians occur in most Eocene samples. The count of Sample 121-752A-16X-CC is unreliable due to very poor preservation; Sample 121-752A-20X-CC is barren, and faunas from all older samples are poorly preserved. The fauna in Sample 121-752A-21R-1, 110-115 cm, is aberrant: all specimens are high spired, globular, and rough walled. The percentage of undeterminable planktonic foraminifers closely corresponds to the state of preservation. The specimens in all samples between Section 121752B-8R-CC and the Cretaceous/Tertiary boundary are de- formed, probably because of compaction of the low-carbonate sediment.

\section{Site 753}

Preservation is moderate to good at Site 753 and few specimens remained unnamed. The calcium carbonate content is very high (more than $90 \%$ ), but fluctuates more below 40 mbsf (Fig. $5 \mathrm{~A})$. At this depth, the weight percent of residue $>40-\mu \mathrm{m}$ drops from $50 \%-60 \%$ to less than $10 \%$ (Fig. 5B). These changes coincide with a hiatus between the upper Oligocene and the middle Eocene. The weight percentages of $>250-$ and $125-250-\mu \mathrm{m}$ material drop slightly downcore (Fig. 5C). This all indicates winnowing, starting in the Oligocene.

The number of $>125-\mu \mathrm{m}$ planktonic foraminifers per gram sediment is very high $(60,000)$ in Sample 121-753A-5H-CC (Oligocene) and low (about 3000) in the older samples from this site (Fig. 5D). The $>250-\mu \mathrm{m}$ planktonic foraminifers constitute $4 \%$ to $8 \%$ of the $>125-\mu \mathrm{m}$ fauna (Fig. $5 \mathrm{E}$ ).

The late Eocene unconformity (Sample 121-753A-6H-CC) is marked by fish teeth, sponge spicules, and calcite rhombs. Preservation is poor and many specimens are broken.

\section{Site 754}

Calcium carbonate content at Site 754 is constant and high (95\%) down to 120 mbsf (the Quaternary, Neogene, and upper Oligocene), then drops abruptly to $70 \%-80 \%$ in the Eocene and Cretaceous, with major fluctuations (Fig. 6A). An interval with very low calcium carbonate content $(20 \%-25 \%)$ occurs at 300 $320 \mathrm{mbsf}$, and no foraminifers could be recovered from this interval. The Quaternary, Neogene, and Oligocene show relatively high residue percentages, which are possibly due to winnowing (Fig. 6B). The size distribution does not reflect this, as the $<125-\mu \mathrm{m}$ fraction constitutes 50 to 60 weight percent of the residue (Fig. 6C). For the Eocene and Cretaceous, samples with much coarse material are of poor quality, whereas others may be of better quality.

Benthic/planktonic ratios show a clear increase downcore, with a peak in the middle Eocene (Figs. 16 and 17). The number of $>125-\mu \mathrm{m}$ planktonic foraminifers per gram sediment is high but fluctuating for the Paleogene and consistently low for the Cretaceous (Fig. 6D). The percentage $>250-\mu \mathrm{m}$ foraminifers of the $>125-\mu \mathrm{m}$ fauna is higher for the Paleogene ( $1 \%$ to $9.5 \%$ ) than for the Cretaceous $(<1 \%)$ (Fig. 6E).

Preservation decreases downcore from good in Samples 121$754 \mathrm{~A}-11 \mathrm{H}-\mathrm{CC}$ through $121-754 \mathrm{~A}-12 \mathrm{H}-\mathrm{CC}$ to very poor in Sample 121-754A-14X-CC. Samples 121-754A-13X-CC to 121$754 \mathrm{~A}-14 \mathrm{X}-\mathrm{CC}(122-132 \mathrm{mbsf})$, from the unconformity, are marked by very poor preservation and abundant glauconite. Cretaceous samples are of poor to very poor quality. Samples 121754B-21R-CC to 121-754B-24R-CC (316-345 mbsf) are barren and were not plotted. The species distribution thus largely reflects preservation, especially for the $>250-\mu \mathrm{m}$ fractions, which commonly contain fewer then 50 specimens. Samples $121-754 \mathrm{~A}-11 \mathrm{H}-$ $\mathrm{CC}$ and 121-754A-12H-CC contain many ostracodes, which indicate an (upper) bathyal depth (W. Meyboom, pers. comm., 1990). Inoceramus is abundant in the upper part of the Cretaceous, down to Sample 121-754B-10R-CC (210 mbsf).

\section{Site 755}

Calcium carbonate content is very low at Site 755 , always less than $60 \%$ and about $30 \%$ on average, whereas volcanic ash content is high (Fig. 7A). The weight percent $>40-\mu \mathrm{m}$ residue reflects sample quality and fluctuates strongly (Fig. 7B). The same is true for the weight distribution of the fractions (Fig. 7C) and the benthic/planktonic ratio (Fig. 18). Benthic/planktonic ratios are $20 \%$ to $40 \%$ in samples of better quality, but may be $100 \%$ in poor 

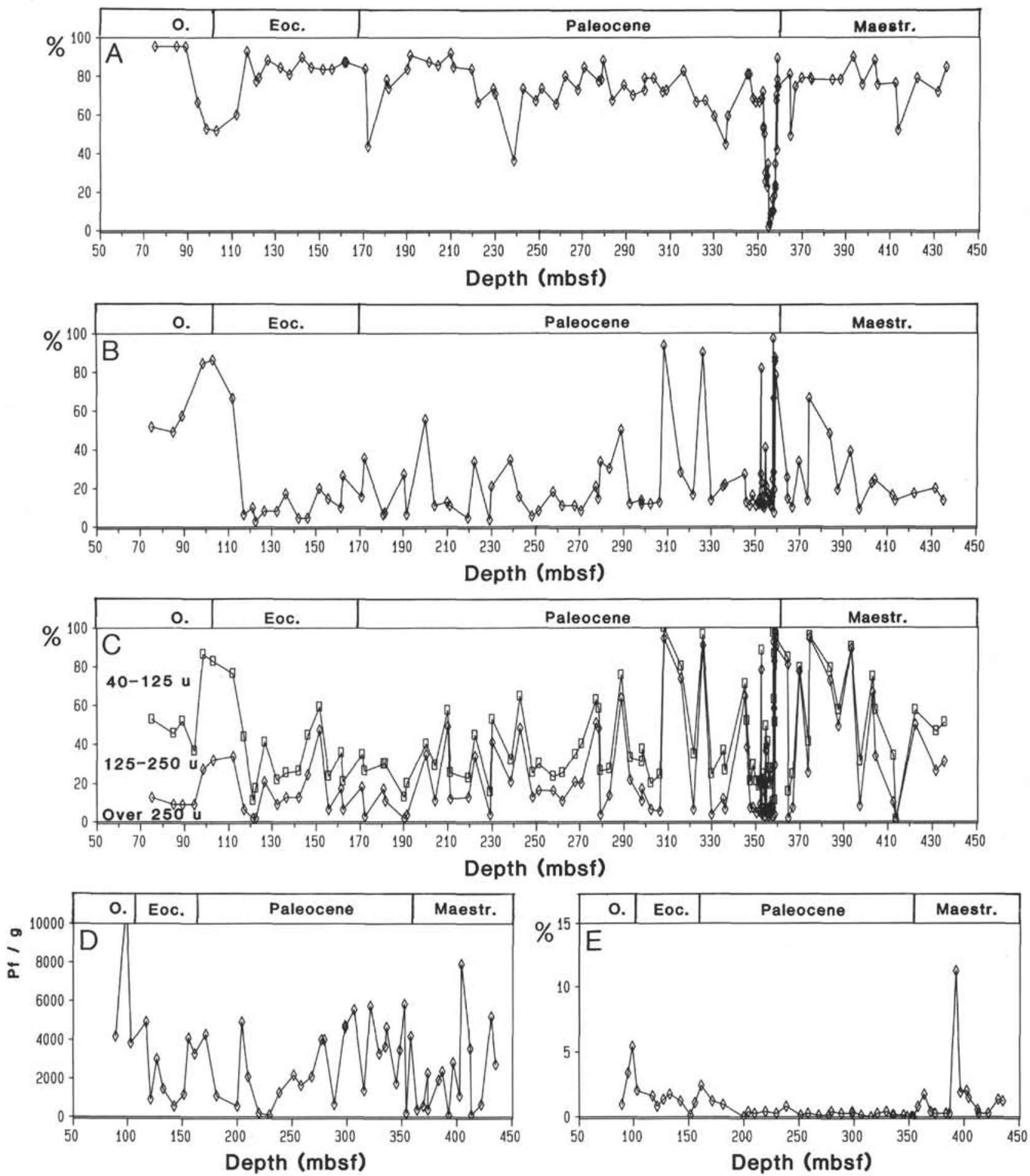

Figure 4. Site 752. Calcium carbonate content (A), weight percent $>40-\mu \mathrm{m}$ residue (B), weight distribution of 40-125-, 125-250-, and $>250-\mu \mathrm{m}$ fractions (C), number of $>125 \mu \mathrm{m}$ planktonic foraminifers per gram dry sample (D), and percentage $>250-\mu \mathrm{m}$ planktonic foraminifers of $>125-\mu \mathrm{m}$ fauna. E. Note scale difference between Figures $4 \mathrm{~A}-4 \mathrm{C}$ and $4 \mathrm{D}$ and $4 \mathrm{E}$.

samples. The number of planktonic foraminifers per gram sample is low to very low, typically only several hundred (Fig. 7D). The $>250-\mu \mathrm{m}$ foraminifers are more common in older samples (Fig. 7E). Preservation is generally very poor, many samples are barren, and many $>250-\mu \mathrm{m}$ fractions contain only a few specimens, which explains the erratic species distributions. Inoceramus prisms and radiolarians are present in most samples.

\section{Site 756}

Calcium carbonate content at Site 756 is uniformly high at about $95 \%$ (Fig. $8 \mathrm{~A}$ ), and the weight percent $>40-\mu \mathrm{m}$ residue fluctuates between $5 \%$ and $35 \%$, with a slight tendency to decrease downcore (Fig. 8B). The weight percent $<125-\mu \mathrm{m}$ residue is about $50 \%$ in the Neogene, increasing to about $70 \%$ in the 

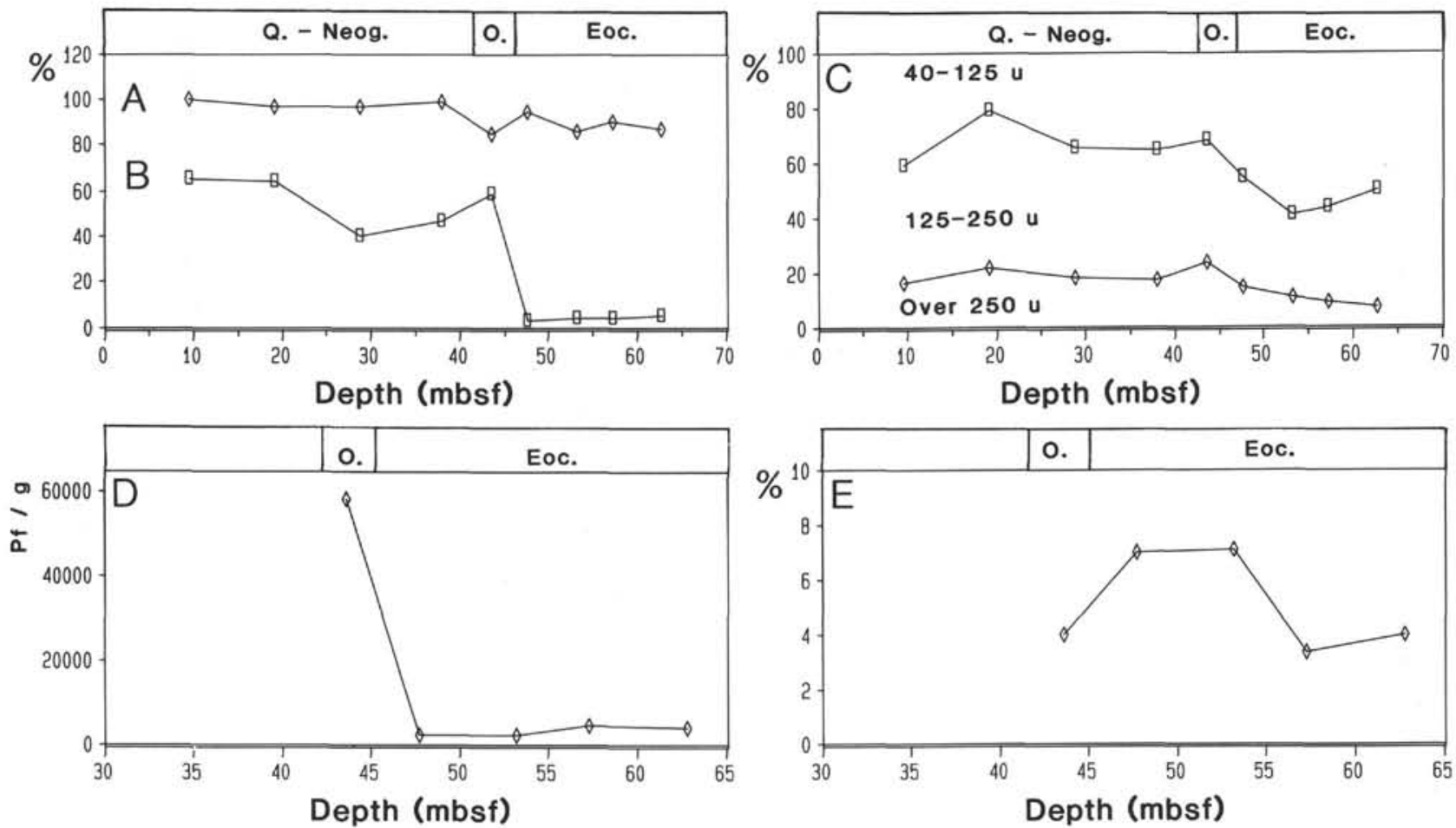

Figure 5. Site 753. Calcium carbonate content (A), weight percent $>40-\mu \mathrm{m}$ residue (B), weight distribution of 40-125-, 125-250-, and $>250-\mu \mathrm{m}$ fractions (C), number of $>125-\mu \mathrm{m}$ planktonic foraminifers per gram dry sample (D), and percentage $>250-\mu \mathrm{m}$ planktonic foraminifers of $>125-\mu \mathrm{m}$ fauna (E). Note scale difference between Figures 5A-5C and 5D and 5E.

Paleogene (Fig. $8 \mathrm{C}$ ). The percentage $>250-\mu \mathrm{m}$ residue is low $(5 \%$ to $10 \%)$.

Although many specimens are broken, preservation is good. Breakage, therefore, probably occurred during sample processing. Large Globigerina species proved most vulnerable.

Planktonic foraminifers are extremely abundant in upper Oligocene sediments (more than 48,000 per gram in Sample 121$756 \mathrm{~B}-8 \mathrm{H}-2,110-115 \mathrm{~cm}$ ), indicating slight winnowing, which removed fine material, such as nannoplankton (Fig. 8D). Older sediments contain 2000 to $15,000>125-\mu \mathrm{m}$ foraminifers per gram. The $>250-\mu \mathrm{m}$ foraminifers are relatively abundant at this site (Fig. 8E). Benthic/planktonic ratios vary from $5 \%$ to $25 \%$, depending on sample quality (Fig. 19).

Glauconite occurs in Sample 121-756C-7H-CC (139 mbsf), indicating a possible hiatus near the Oligocene/Eocene boundary. Reworking is fairly common, and Globigerinatheka index (Finlay, 1939a) was found in Samples 121-756B-8H-CC and 121756B-9H-CC. Ostracodes are common in Samples 121-756B$8 \mathrm{H}-1,110-115 \mathrm{~cm}$, to $121-756 \mathrm{~B}-9 \mathrm{H}-1,110-115 \mathrm{~cm}$, and they indicate a probable upper bathyal depth (W. Meyboom, pers. comm., 1990). Sample 121-756C-6X-CC contains fish teeth and reworked foraminifers, and fish teeth are also present in Sample 121-756C-7X-CC. Samples 121-756C-8X-CC and 121-756C$9 \mathrm{X}-\mathrm{CC}$ were too indurated to yield any foraminifers.

\section{Site 757}

Calcium carbonate content at Site 757 is high (90\%) down to 210 mbsf (the Quaternary, Neogene, Oligocene, and most of the Eocene), then drops abruptly to less than $10 \%$ in the Paleocene, which consists largely of volcanogenic material (Fig. 9A). The weight percent $>40-\mu \mathrm{m}$ residue drops from $50 \%$ to $10 \%$ within the Neogene and to $5 \%$ in the Oligocene and Eocene. Lower
Eocene and older samples yield up to $75 \%$ residue, consisting of volcanic ash and tuff and pebbles of undisintegrated material (Fig. 9B). The $>250-\mu \mathrm{m}$ material constitutes 40 weight percent of the Neogene samples, dropping abruptly to $5 \%$ in the Oligocene (Fig. 9C). The $<125-\mu \mathrm{m}$ material accounts for more than $70 \%$ of the Oligocene residues. The Oligocene is thin $(20 \mathrm{~m})$ but complete, and there are thus no indications of strong winnowing. The high $>250-\mu \mathrm{m}$ material content in the Neogene may be caused by strong winnowing. The $>250-\mu \mathrm{m}$ material content is $40 \%$ in the upper Eocene, decreasing to $20 \%$ in the lower Eocene. This is probably caused by dissolution, as preservation is poor.

The number of $>125-\mu \mathrm{m}$ planktonic foraminifers is generally low, at 500 to 4000 per gram sample (Fig. 9D). Sample 121-757B$11 \mathrm{H}-2,110-115 \mathrm{~cm}$, (lower Miocene) contains more than 6000 foraminifers per gram, and Samples 121-757B-22X-CC and 121757B-23X-CC contain more than 10,000 foraminifers per gram. The $>250$-mm foraminifers account for less than $5 \%$ of the $>125$ $\mu \mathrm{m}$ fauna for the Oligocene, again arguing against strong winnowing (Fig. 9E). In the upper Eocene the $>250-\mu \mathrm{m}$ foraminifers make up $20 \%$ to $60 \%$ of the fauna, indicating severe winnowing or dissolution of smaller, thin-walled foraminifers. In these faunas many specimens are corroded or broken. Dissolution, therefore, seems more likely. Smaller foraminifers are more abundant in the middle and lower Eocene, accounting for $80 \%$ to $90 \%$ of the $>125-\mu \mathrm{m}$ fauna.

The benthic/planktonic ratios are generally low, with peaks in the upper Eocene and lower Eocene (Figs. 20 and 21).

The faunas from Samples 121-757B-16H-CC to 121-757B$20 \mathrm{H}-\mathrm{CC}$ consist largely of indistinct, rough-walled, globular species. Samples 121-757B-23X-CC and 121-757B-24X-3, 46-48 $\mathrm{cm}$, contain glauconite and a poorly preserved fauna. Samples 121-757B-24X-CC to 121-757B-26X-CC yielded no microfauna at all. 

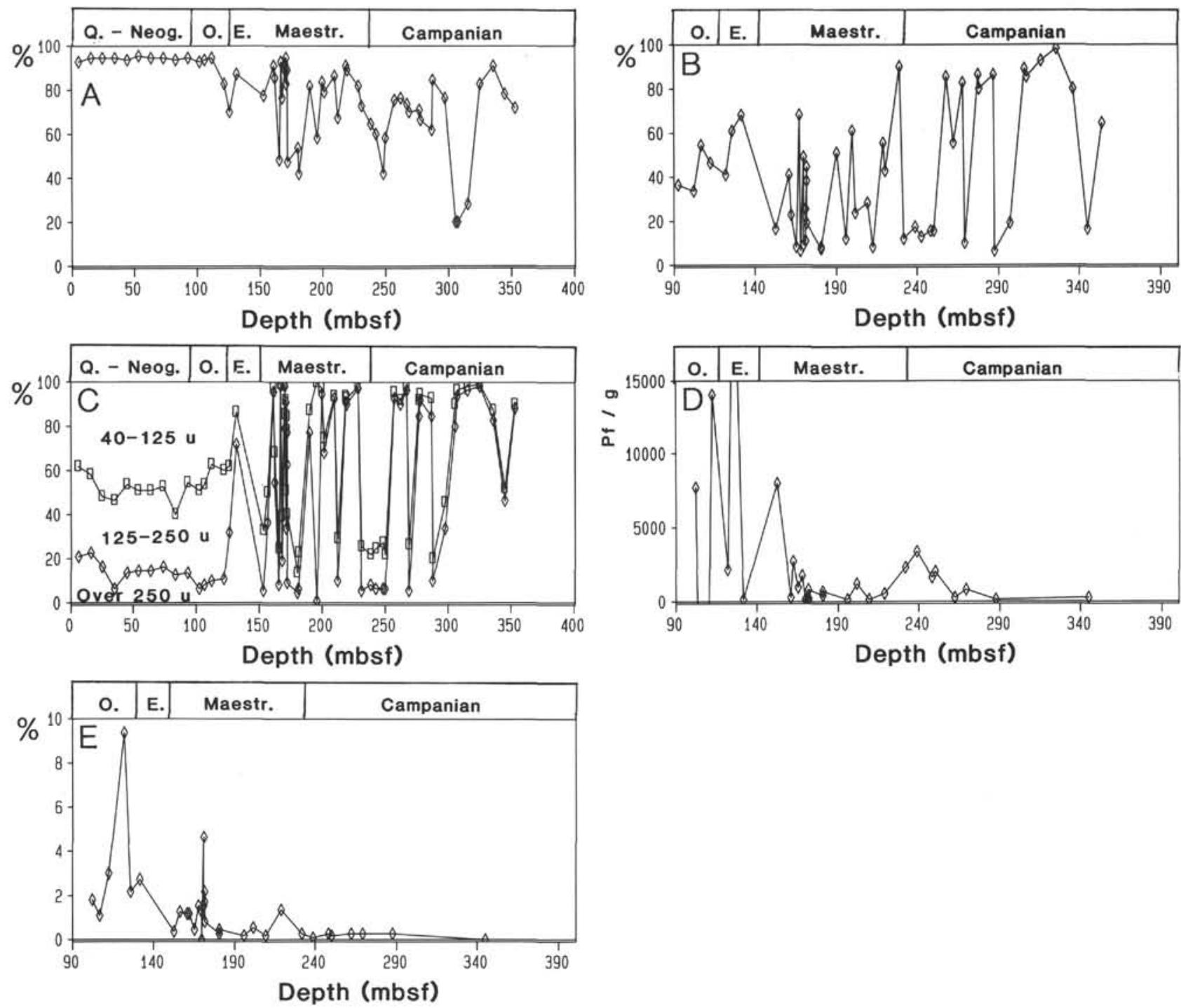

Figure 6. Site 754. Calcium carbonate content (A), weight percent $>40-\mu \mathrm{m}$ residue (B), weight distribution of 40-125-, 125-250-, and $>250-\mu \mathrm{m}$ fractions (C), number of $>125-\mu \mathrm{m}$ planktonic foraminifers per gram dry sample (D), and percentage $>250-\mu \mathrm{m}$ planktonic foraminifers of $>125-\mu \mathrm{m}$ fauna (E). Note different scales.

\section{Site 758}

Calcium carbonate content at Site 758 is about $60 \%$ in the most recent sediments, increasing to about $90 \%$ in the upper Paleogene sediments (Fig. 10A). This reflects increasing terrigenous input during the Neogene as the Himalayan mountain chain formed. Carbonate content is even higher from 180 to 300 mbsf (the Oligocene and Paleocene), up to $95 \%$. Downcore, the carbonate content decreases rapidly as volcanic ash becomes a more important component, and below 420 mbsf carbonate content is rarely higher than $20 \%$. The weight percent $>40-\mu \mathrm{m}$ residue is low (generally less than 20\%) for the entire Tertiary and uppermost Cretaceous (Fig. 10B). The residue content is higher for the older samples, reflecting both volcanic ash content and poorer sample quality. Neogene residues contain more $>250-\mu \mathrm{m}$ weight percent material than those of the Paleogene ( $15 \%$ to $20 \%$ vs. $5 \%$ to $15 \%$ ) and less $<125-\mu \mathrm{m}$ material (Fig. 10C). Coarse material constitutes a larger part of Cretaceous sample residues, again reflecting both volcanic ash content and sample quality.

The number of $>125-\mu \mathrm{m}$ planktonic foraminifers per gram sample decreases from about 10,000 for the upper Oligocene to less than 2000 for the lower Oligocene, indicating winnowing, especially during the early Oligocene (Fig. 10D). The upper Paleocene contains more than 25,000 foraminifers per gram sediment, decreasing to about 5000 in the Upper Cretaceous. With one exception (Sample 121-758A-42X-3, 111-114 cm, which is poorly sieved and contains more than 9000 foraminifers per gram, mostly very small Heterohelicidae) the number then decreases to 500 to 1000 for the Campanian sediments. The $>250-\mu \mathrm{m}$ foraminifers are most abundant in the upper Paleocene, constituting up to $20 \%$ of the $>125-\mu \mathrm{m}$ fauna, reflecting the favorable circumstances for large Morozovella species (Fig. 10E). The consistent and fairly high percentage of $>250-\mu \mathrm{m}$ foraminifers in the lower Oligocene (about $15 \%$ ) suggests winnowing. This diminishes in the middle Oligocene, where $>250-\mu \mathrm{m}$ foraminifers become much rarer. Lower Maestrichtian and Campanian faunas contain very few $>250-\mu \mathrm{m}$ foraminifers, reflecting unfavorable circumstances for larger planktonic foraminifers at high latitudes. The shift from a cold to a warm climate occurred in the late Maestrichtian, resulting in both more specimens and more species.

Benthic/planktonic ratios are generally low in Paleogene faunas (Figs. 22-24), especially for the Paleocene. A benthic/plank- 

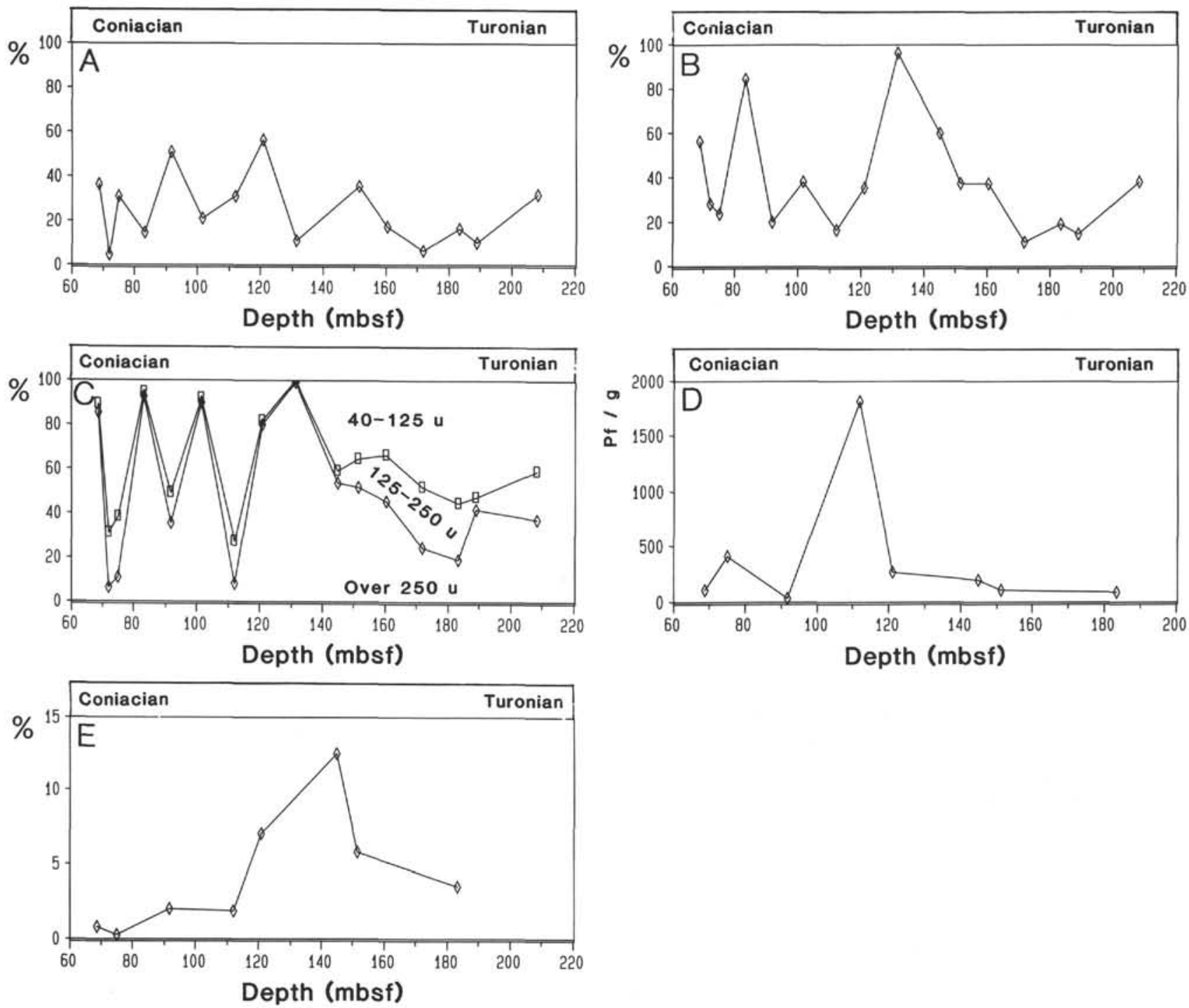

Figure 7. Site 755. Calcium carbonate content (A), weight percent $>40-\mu \mathrm{m}$ residue (B), weight distribution of 40-125-, 125-250-, and $>250-\mu \mathrm{m}$ fractions (C), number of $>125-\mu \mathrm{m}$ planktonic foraminifers per gram dry sample (D), and percentage $>250-\mu \mathrm{m}$ planktonic foraminifers of $>125-\mu \mathrm{m}$ fauna $(\mathbf{E})$.

tonic ratio peak occurs at $256 \mathrm{mbsf}$ (Sample 121-758A-27X-CC), where Eocene faunas are present within a hardground. Cretaceous faunas yield higher benthic/planktonic ratios, which increase from 5\% in upper Maestrichtian to $30 \%$ (125-250- $\mu \mathrm{m}$ fraction) and $90 \%$ ( $>250-\mu \mathrm{m}$ fraction) in the Campanian samples (Fig. 25).

Preservation of Oligocene and Paleocene material is excellent, but the Eocene material is poorly preserved and mixed with fish teeth, glauconite, quartz grains, and felspar grains. Radiolarians are common and well preserved in all Oligocene samples. Cretaceous material is poorly preserved except for the uppermost Maestrichtian. Inoceramus prisms are common, and volcanic ash content increases downcore. Preservation is very poor below 400 mbsf (Sample 121-758A-44X-CC).

\section{Biostratigraphy}

\section{Site 752 (Figs. 11-14 and Table 2)}

We assign Sample 121-752A-10H-2, 110-115 cm (89 mbsf), to the Oligocene-Miocene (Zones P22/N4). Globoquadrina dehiscens (Chapman, Parr, and Collins, 1934) and Globigerina praebulloides Blow, 1959 dominate the $>250-\mu \mathrm{m}$ fraction. The $125-250-\mu \mathrm{m}$ fraction is dominated by Globigerinita glutinata
(Egger, 1893), Globorotaloides suteri Bolli, 1957a, and G. praebulloides Blow, 1959. Important rarer species include Globigerina ciperoensis Bolli, 1954, G. angulisuturalis Bolli, 1957a, and Fohsella kugleri (Bolli, 1957a).

Sample 121-752A-10H-CC (95 mbsf) is of early Oligocene age, based on abundant Globigerina linaperta Finlay, 1939a in the $>250-\mu \mathrm{m}$ fraction and Chiloguembelina cubensis (Palmer, 1934 ) in the 125-250-mm fraction and the absence of Acarinina.

Samples $121-752 \mathrm{~A}-11 \mathrm{H}-3,110-115 \mathrm{~cm}$, to $121-752 \mathrm{~A}-12 \mathrm{X}$ CC (102-111 mbsf) are of middle Eocene age (Zones P13-14). Acarinina densa (Cushman, 1925b) is common, and Globigerinatheka sp. cf. G. index (Finlay, 1939a) dominates the $>250-\mu \mathrm{m}$ fractions. In the $125-250-\mu \mathrm{m}$ fractions, additional species include Acarinina coalingensis (Cushman and Hanna, 1927), Catapsydrax howei (Blow and Banner, 1962), Globigerina linaperta Finlay, 1939a (Sample 121-752A-11H-3, 110-115 cm), and Truncorotaloides rohri Brönnimann and Bermúdez, 1953 (Sample 121-752A-11H-CC).

The lower middle Eocene, Zones P10 to P12, is defined by the presence of Globigerina frontosa Subbotina, 1953, Acarinina pentacamerata (Subbotina, 1947), and Morozovella aragonensis (Nuttall, 1930) in Samples 121-752A-13X-3, 5-8 cm, to 121 - 

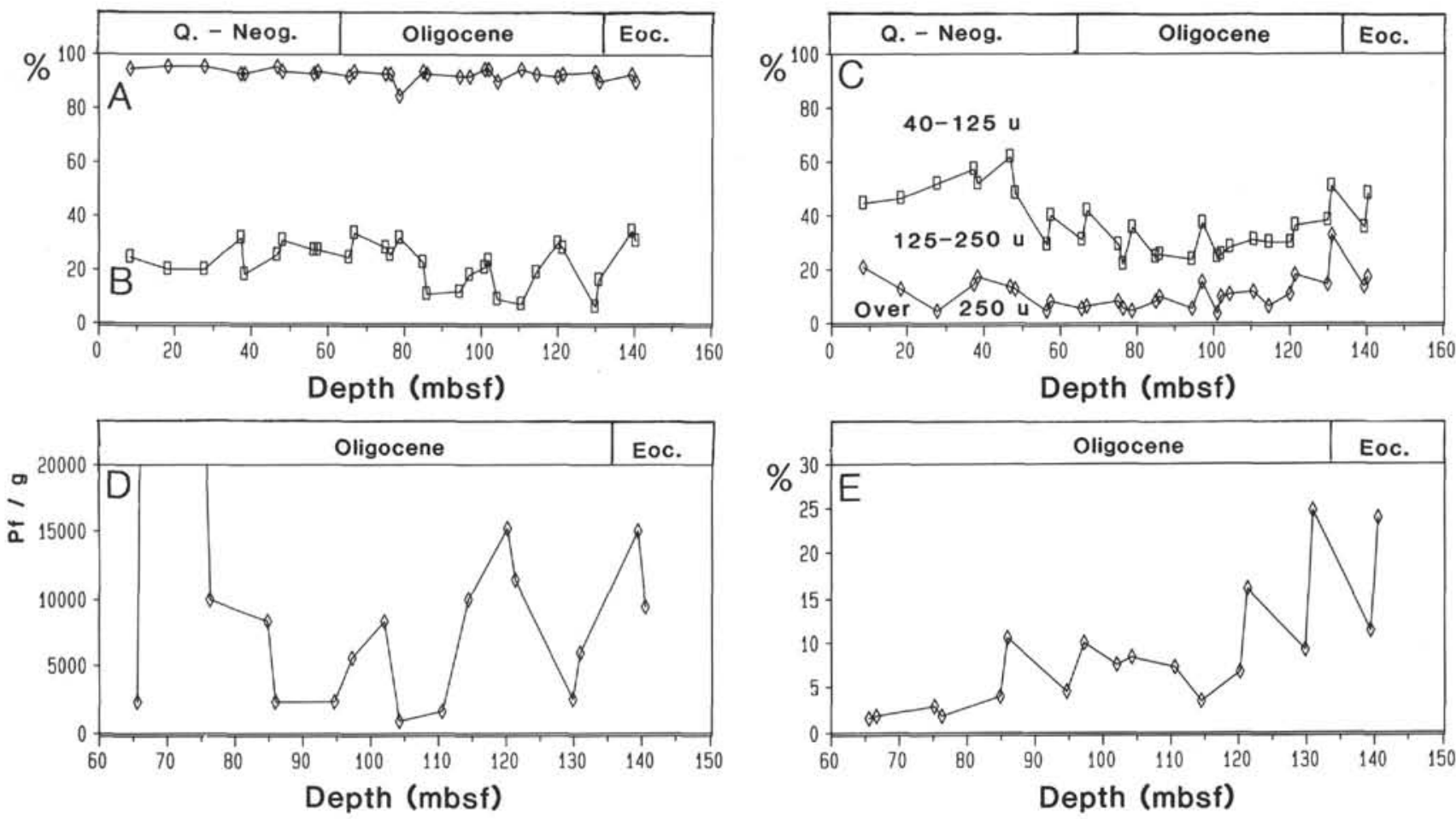

Figure 8. Site 756. Calcium carbonate content (A), weight percent $>40-\mu \mathrm{m}$ residue (B), weight distribution of 40-125-, 125-250-, and $>250-\mu \mathrm{m}$ fractions (C), number of $>125-\mu \mathrm{m}$ planktonic foraminifers per gram dry sample (D), and percentage $>250-\mu \mathrm{m}$ planktonic foraminifers of $>125-\mu \mathrm{m}$ fauna $(\mathbf{E})$. Note scale difference between Figures $8 \mathrm{~A}-8 \mathrm{C}$ and $8 \mathrm{D}$ and $8 \mathrm{E}$.

$752 \mathrm{~A}-14 \mathrm{X}-\mathrm{CC}$ and $121-752 \mathrm{~B}-2 \mathrm{R}-1,115-118 \mathrm{~cm}$. A. coalingensis dominates the $>250-\mu \mathrm{m}$ fractions, together with Globigerina eocaena Guembel, 1868. The $125-250-\mu \mathrm{m}$ fractions are almost completely dominated by small, compact Acarinina spp.

The middle/lower Eocene boundary is placed at about 137 mbsf, between Samples 121-752A-14X-CC and 121-752A-15X$\mathrm{CC}$, based on the first appearance of Globigerina frontosa, $G$. eocaena, Acarinina pentacamerata, and Catapsydrax howei. We could not zone the lower Eocene (Zones P6-9, Samples 121$752 \mathrm{~A}-15 \mathrm{X}-\mathrm{CC}$ to $121-752 \mathrm{~A}-17 \mathrm{X}-\mathrm{CC}, 137-162 \mathrm{mbsf}$ ) because of the lack of marker species. Compact Acarinina species dominate both fractions. Morozovella marginodentata (Subbotina, 1953) and M. subbotinae (Morozova, 1939) are rare, Globigerina linaperta is common in all samples, and large Chiloguembelina wilcoxensis is rare to common.

The occurrence of Globigerina velascoensis Cushman, 1925d and Morozovella aequa (Cushman and Renz, 1942) in Sample 121-752A-18X-CC indicates the uppermost Paleocene (Zone P5). Samples 121-752A-18X-CC to 121-752A-22X-3, 110-115 cm, (169-203 mbsf) represent Zone P5, with G. linaperta, G. spiralis Bolli, 1957b, G. triangularis White, 1928, and rare Acarinina sp. cf. A. pentacamerata and A. gravelli (Brönnimann, 1952a).

Because Planorotalites pseudomenardii (Bolli, 1957b) is rare (1.2\% in Sample 121-752A-22R-CC) and keeled Morozovella species are absent, we cannot separate Zones P3b and P4. A. coalingensis is abundant to dominant, and A. mckannai (White, 1928 ) is rare. We consider their first appearances in Sample 121-752A-28X-CC (268 mbsf) as indicative for the base of Zone P3b.

Samples 121-752A-29X-CC and 121-752A-30X-CC (277$280 \mathrm{mbsf}$ ) contain Morozovella angulata (White, 1928) (together with abundant $M$. uncinata (Bolli, 1957b)), indicating Zone P3a.
M. uncinata without M. angulata occurs in Sample 121-752A31X-CC (288 mbsf), indicating Zone P2.

We assign Samples 121-752B-5R-1, 118-121 cm, to 121752B-8R-CC (298-335 mbsf) to Zone P1b, with Morozovella pseudobulloides (Plummer, 1926), Globigerina triloculinoides Plummer, 1926, and Planorotalites compressa (Plummer, 1926), and without species from Zone P1a, like Globigerina fringa Subbotina, 1950 and G. edita Subbotina, 1953.

These two species indicate Zone P1a in Samples 121-752B$9 \mathrm{R}-1,56-59 \mathrm{~cm}$, to $121-752 \mathrm{~B}-10 \mathrm{R}-6,130-131 \mathrm{~cm}(336-353.5$ mbsf). The fauna in these samples is small sized, poorly preserved, and commonly crushed or deformed.

All samples from Sections 121-752B-10R-7, 121-752B-11R-1, and 121-752B-11R-2 are entirely barren, as is Sample 121-752B$11 \mathrm{R}-3,88-89 \mathrm{~cm}(353.7-358.7 \mathrm{mbsf})$. These samples are taken from the interval immediately above the Cretaceous/Tertiary boundary.

We assign Samples 121-752B-11R-3, 96-97 cm, to 121-752B$17 \mathrm{R}-1,106-109 \mathrm{~cm}$, to the Abathomphalus mayaroensis Zone, but the marker species is very rare. Several species of Heterohelicidae and Globotruncanidae are restricted to this zone, and $\mathrm{Ar}$ chaeoglobigerina, Globigerinelloides, and some species of Heterohelix are more common in older samples.

It is interesting that Rugoglobigerina hexacamerata Brönnimann, 1952a occurs in the oldest samples, grading into Rugotruncana subcircumnodifer (Gandolfi, 1955) in the lower part of the A. mayaroensis Zone. Therefore, we maintain Rugotruncana as a valid genus, in disagreement with Robaszynski et al. (1984), who denied the existence of this genus. It also indicates the close relationship between Archaeoglobigerina, Rugoglobigerina, and Rugotruncana. Also remarkable is the abundance of Rugoglobigerina rugosa. This species is much rarer in the Cretaceous at Site 

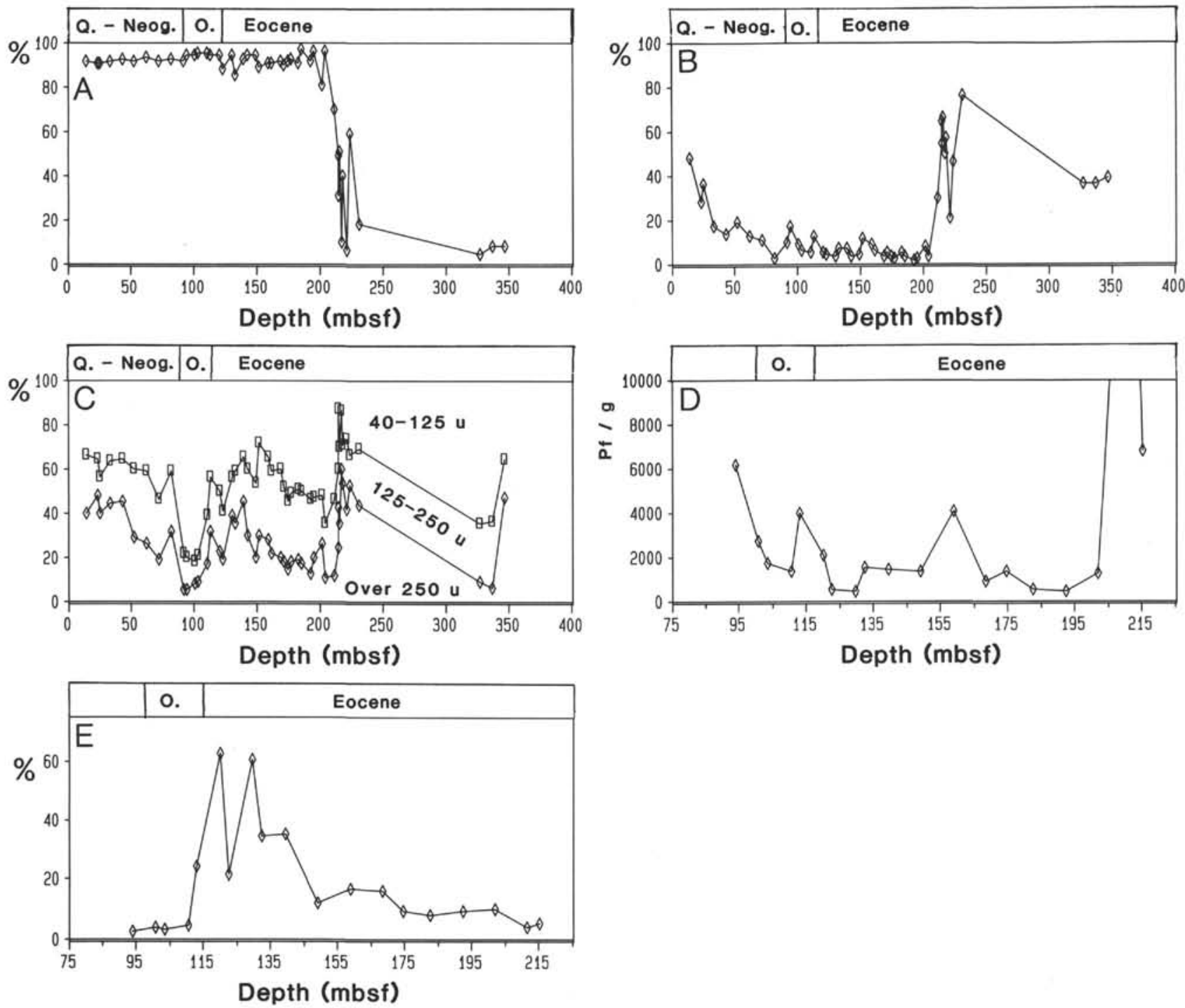

Figure 9. Site 757. Calcium carbonate content (A), weight percent $>40-\mu \mathrm{m}$ residue (B), weight distribution of 40-125-, 125-250-, and $>250-\mu \mathrm{m}$ fractions (C), number of $>125-\mu \mathrm{m}$ planktonic foraminifers per gram dry sample (D), and percentage $>250-\mu \mathrm{m}$ planktonic foraminifers of $>125-\mu \mathrm{m}$ fauna $(\mathbf{E})$. Note scale difference between Figures 9A-9C and 9D and 9E.

758. Latitude difference may be the cause, as Site 752 was situated at about $50^{\circ} \mathrm{S}$ and Site 758 at about $35^{\circ} \mathrm{S}$ (Fig. 1).

\section{Site 753 (Fig. 15 and Table 3)}

The $>250-\mu \mathrm{m}$ fraction of Sample 121-753A-5H-CC (44 mbsf) contains Globigerina euapertura Jenkins, 1960, G. angiporoides Hornibrook, 1965, G. tripartita Koch, 1926, and Globoquadrina praedehiscens Blow and Banner, 1962. The 125-250- $\mu \mathrm{m}$ fraction contains abundant Globigerinita glutinata (Egger, 1893) and Globorotaloides suteri Bolli, 1957a, plus rarer Fohsella kugleri (Bolli, 1957a), Globigerina praebulloides Blow, 1959, and G. sp. cf. G. quinqueloba Natland, 1938. This indicates a late Oligocene age, Zone P22.

All other samples except $121-753 \mathrm{~A}-7 \mathrm{H}-\mathrm{CC}$ are of middle Eocene age, Zones P12-14 and possibly as old as Zone P11. Acarinina coalingensis (Cushman and Hanna, 1927) and A. densa (Cushman, 1925b) dominate the $>250-\mu \mathrm{m}$ fractions, with $A$. coalingensis and Morozovella convexa (Subbotina, 1953) dominating the $125-250-\mu \mathrm{m}$ fractions. Globigerina linaperta Finlay, 1939a is present but rare in both fractions, and Pseudohastigerina micra (Cole, 1927) occurs in the $125-250-\mu \mathrm{m}$ fractions.
The occurrence of Globigerina frontosa Subbotina, 1953 in Sample 121-753A-7H-CC (62 mbsf) assigns this sample to the early middle Eocene, Zones P10-12. Otherwise, this sample resembles the previous samples. Guembelitria columbiana Howe, 1939 is common to abundant in the $<125-\mu \mathrm{m}$ fraction of Samples 121-753A-6H-3, 110-115 cm, 121-753A-6H-CC, and 121-753A7H-CC. Pseudohastigerina naguewichiensis (Myatliuk, 1950) occurs in the $<125-\mu \mathrm{m}$ fraction of Samples $121-753 \mathrm{~A}-6 \mathrm{H}-3$, $110-115 \mathrm{~cm}$, and 121-753A-7H-CC.

\section{Site 754 (Figs. 16 and 17 and Table 4)}

The $>250-\mu \mathrm{m}$ fraction of Samples 121-754A-11H-CC and 121-754A-12H-3, 110-115 cm, (102.5-107 mbsf) are dominated by Globigerina euapertura Jenkins, 1960. Globoquadrina praedehiscens Blow and Banner, 1962, Globigerina tripartita Koch, 1926, and Catapsydrax unicavus Bolli, Loeblich, and Tappan, 1957 are common. The $125-250-\mu \mathrm{m}$ fractions are dominated by Globorotaloides suteri Bolli, 1957a and Globigerinita glutinata (Egger, 1893). Also present are Globigerina angustiumbilicata Bolli, 1957a, Fohsella kugleri (Bolli, 1957a), Jenkinsella continuosa/J. nana, Jenkinsella mayeri (Cushman and Ellisor, 

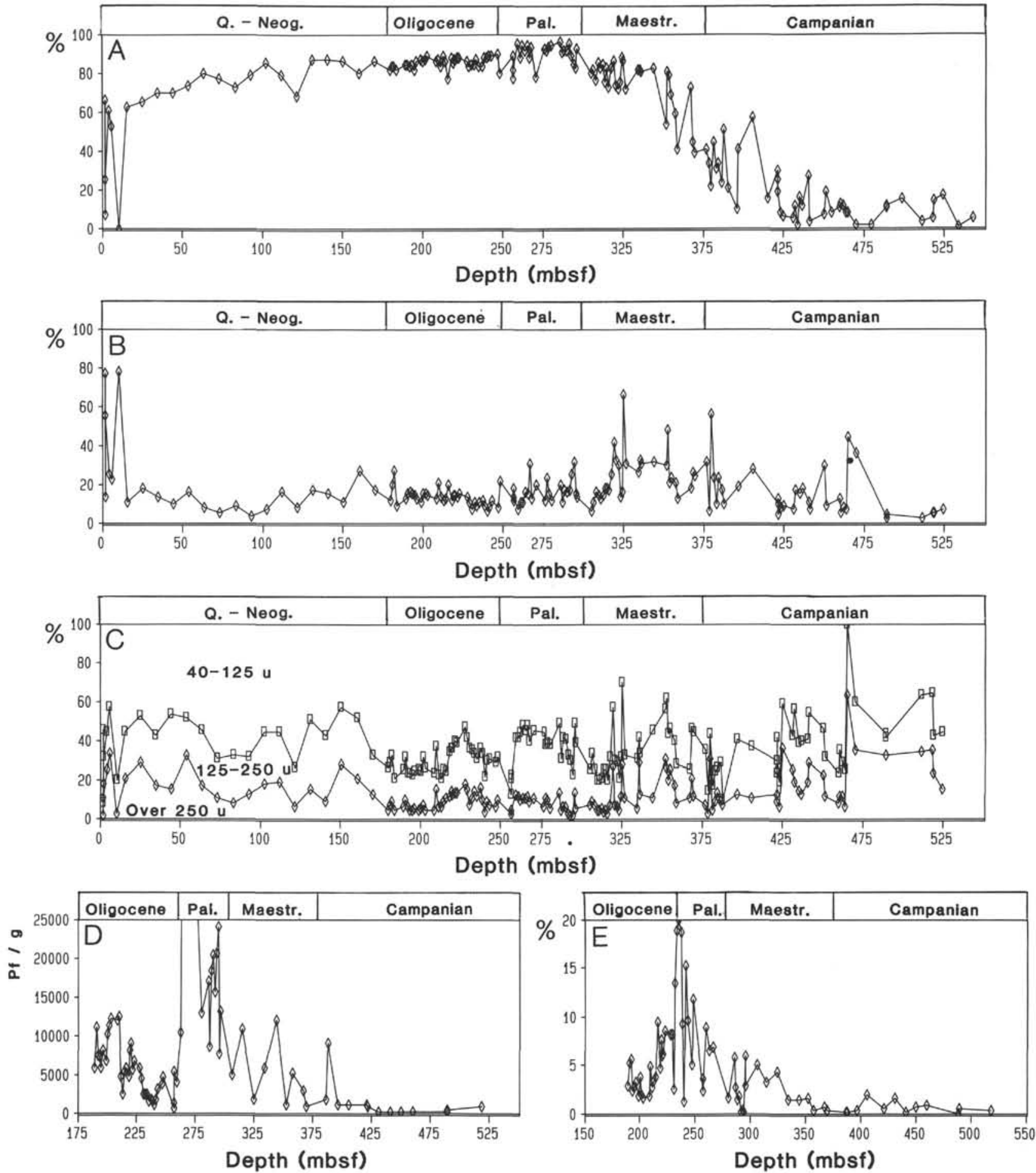

Figure 10. Site 758. Calcium carbonate content (A), weight percent $>40-\mu \mathrm{m}$ residue (B), weight distribution of 40-125-, 125-250-, and $>250-\mu \mathrm{m}$ fractions (C), number of $>125-\mu \mathrm{m}$ planktonic foraminifers per gram dry sample (D), and percentage $>250-\mu \mathrm{m}$ planktonic foraminifers of $>125-\mu \mathrm{m}$ fauna $(\mathbf{E})$. Note scale difference between Figures $10 \mathrm{~A}-10 \mathrm{C}$ and $10 \mathrm{D}$ and $10 \mathrm{E}$.

1939), and Zeaglobigerina woodi (Jenkins, 1960). Sample 121754A-11H-CC also contains Globoquadrina dehiscens (Chapman, Parr, and Collins, 1934) $(>250-\mu \mathrm{m})$. This clearly indicates an Oligocene-Miocene age (P22/N4). Sample 121-754A-12H-3, $110-115 \mathrm{~cm}$, we date as late Oligocene, Zone P22. Because Chiloguembelina cubensis (Palmer, 1934) is present in the $<125-\mu \mathrm{m}$ fraction it must be close to Zone P21. On this basis, we date Sample 121-754A-12H-CC as Zone P21, although we did not see its marker species, Jenkinsella opima (Bolli, 1957a). The $125-250-\mu \mathrm{m}$ fraction contains both Globigerinita glutinata and Globigerina officinalis Subbotina, 1953, also indicating a middle Oligocene age.

The $>250-\mu \mathrm{m}$ fraction of Sample 121-754A-13X-CC contains both J. opima and Turborotalia increbescens (Bandy, 1949). It 

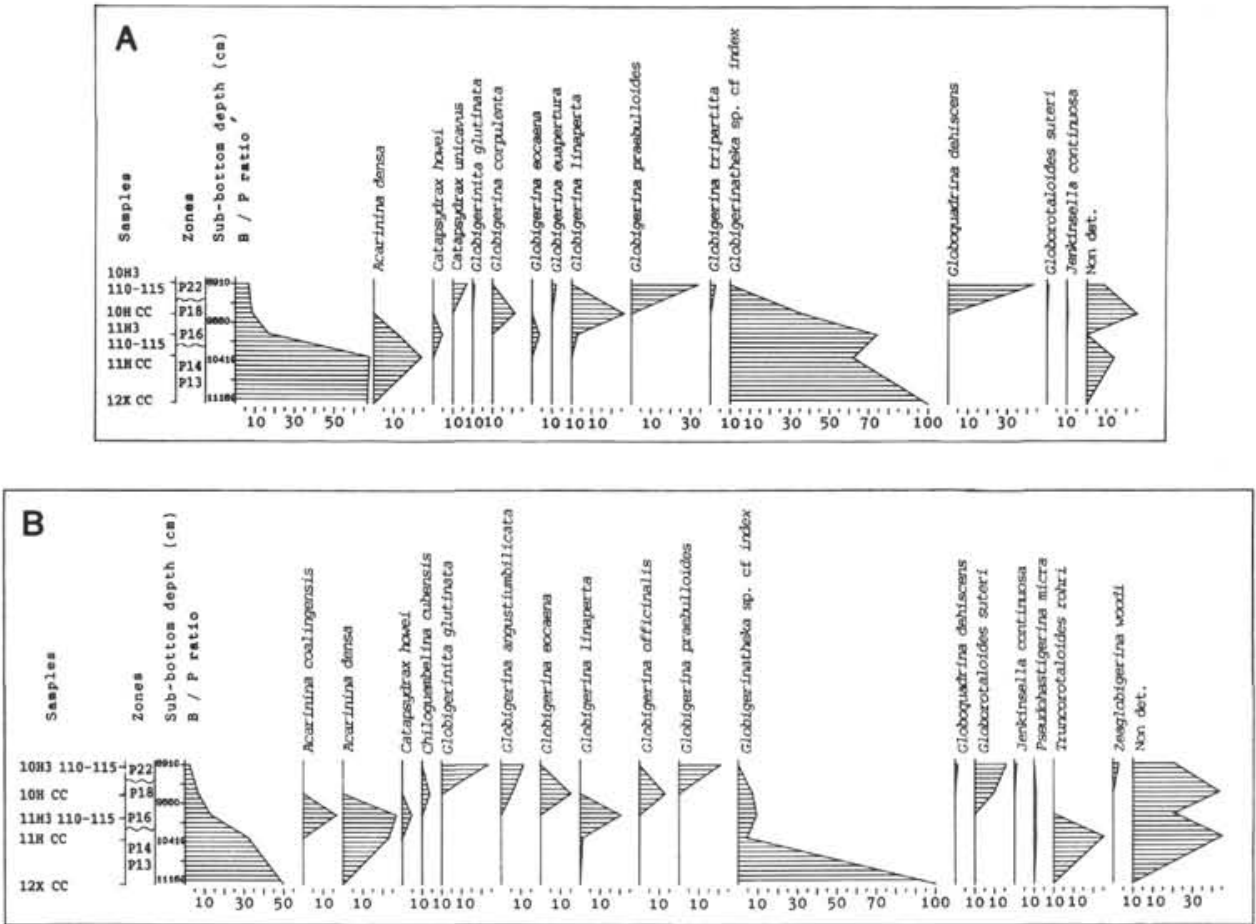

Figure 11. Frequency distribution of selected middle Eocene-Oligocene planktonic foraminifers from Hole 752A. Vertical scale 1:750. A. Specimens $>250 \mu \mathrm{m}$. B. Specimens $125-250 \mu \mathrm{m}$.

also contains glauconite and (reworked) Eocene fauna. We date this sample as early Oligocene, Zone P20. We consider the record of Globigerina ampliapertura Bolli, 1957a in Sample 121-754A$12 \mathrm{H}-\mathrm{CC}$ as erroneous.

Sample 121-754A-14X-3, 110-115 cm (126 mbsf), contains few foraminifers, mostly Globigerinatheka sp. cf. G. index (Finlay, 1939a) and Globigerina eocaena Guembel, 1868. In the 125-250- $\mu \mathrm{m}$ fraction Acarinina coalingensis (Cushman and Hanna, 1927) and A. densa (Cushman, 1925b) occur. The 125$250-\mu \mathrm{m}$ fraction of Sample 121-754A-14X-CC contains few recognizable foraminifers. We recognized Acarinina densa, Globigerina linaperta, and Globigerinatheka index, together with a few specimens of Truncorotaloides rohri Brönnimann and Bermúdez, 1953. This indicates a (late?) middle Eocene age, Zones P13-14 and perhaps Zone P12.

Abathomphalus mayaroensis (Bolli, 1951) occurs in Sample 121-754B-5R-CC (161 mbsf), establishing overlap with Site 752. This is also the only good dating possible in the Cretaceous at this site.

The $>250-\mu \mathrm{m}$ fraction of all Cretaceous samples is dominated by Archaeoglobigerina spp., usually A. australis Huber, 1990. Globotruncana arca (Cushman, 1926) occurs commonly down to Sample 121-754B-13R-2, 110-113 cm (231 mbsf), and is very rare below that. The $125-250-\mu \mathrm{m}$ fractions are dominated by Globigerinelloides multispinatus/G. volutus, Heterohelix planata (Cushman, 1938), and H. globulosa (Ehrenberg, 1840).

Heterohelix punctulata (Cushman, 1938) is common in Samples 121-754B-11R-CC, 121-754B-12R-CC, and 121-754B-13RCC (219-238 mbsf). According to Pessagno (1967), in Texas this species is most abundant in the upper Campanian. Therefore, we place the Campanian/Maestrichtian boundary above this interval.

\section{Site 755 (Fig. 18)}

The genus Marginotruncana (mainly $M$. marginata (Reuss, 1854 ) and $M$.pseudolinneiana Pessagno, 1967) occurs in Samples 121-755A-5R-2, 61-64 cm, to 121-755A-11R-1, 65-68 cm, (67-
121 mbsf), assigning them to the late Turonian-Coniacian. We cannot reconcile this with the Santonian date for Sample 121755A-5R-2, 61-64 cm, which was arrived at on board.

Samples 121-755A-13R-4, 16-19 cm, to 121-755A-17R-3, $114-119 \mathrm{~cm},(144-183 \mathrm{mbsf})$ contain Dicarinella species (D. canaliculata (Reuss, 1854), D. hagni (Scheibnerova, 1962), D. imbricata (Mornod, 1949-1950), and D. primitiva (Dalbiez, 1955)) and Whiteinella baltica Douglas and Rankin, 1969. This implies a middle to possibly early Turonian age for these samples.

\section{Site 756 (Fig. 19 and Table 5)}

Samples 121-756B-7H-CC and 121-756B-8H-1, 110-115 cm, (66-67 mbsf) are of early Miocene age (Zone N4). Globoquadrina dehiscens (Chapman, Parr, and Collins, 1934) and G. praedehiscens Blow and Banner, 1962 are common in the $>250-\mu \mathrm{m}$ fractions, and Globigerinoides species are rare. In the $125-250-\mu \mathrm{m}$ fractions the most important species are Fohsella kugleri (Bolli, 1957a), Globigerinita glutinata (Egger, 1893), and Globorotaloides suteri Bolli, 1957a.

Zone P22 is represented by Samples 121-756B-8H-CC to 121-756B-9H-CC (75-85 mbsf), with dominant Globigerina euapertura Jenkins, 1960 and rare to common Catapsydrax unicavus Bolli, Loeblich, and Tappan, 1957, Globigerina galavisi Bermúdez, 1960, G. praebulloides Blow, 1959, G. sellii (Borsetti, 1959 ), and $G$. praedehiscens in the $>250-\mu \mathrm{m}$ fractions. In the $125-250-\mu \mathrm{m}$ fractions Globigerinita glutinata (Egger, 1893) and Globorotaloides suteri are dominant. Other species are Globigerina angustiumbilicata Bolli, 1957a, Jenkinsella continuosa (Blow, 1959), and J. nana (Bolli, 1957a). Chiloguembelina cubensis (Palmer, 1934) is present in the $<125-\mu \mathrm{m}$ fraction of Sample 121-756A-8H-CC.

The absence of J. opima (Bolli, 1957a) makes recognition of Zone P21 difficult. We consider the transition from Globigerina officinalis Subbotina, 1953 to Globigerinita glutinata (Egger, 1893) between Samples 121-756B-9H-CC and 121-756B-10H-1, 

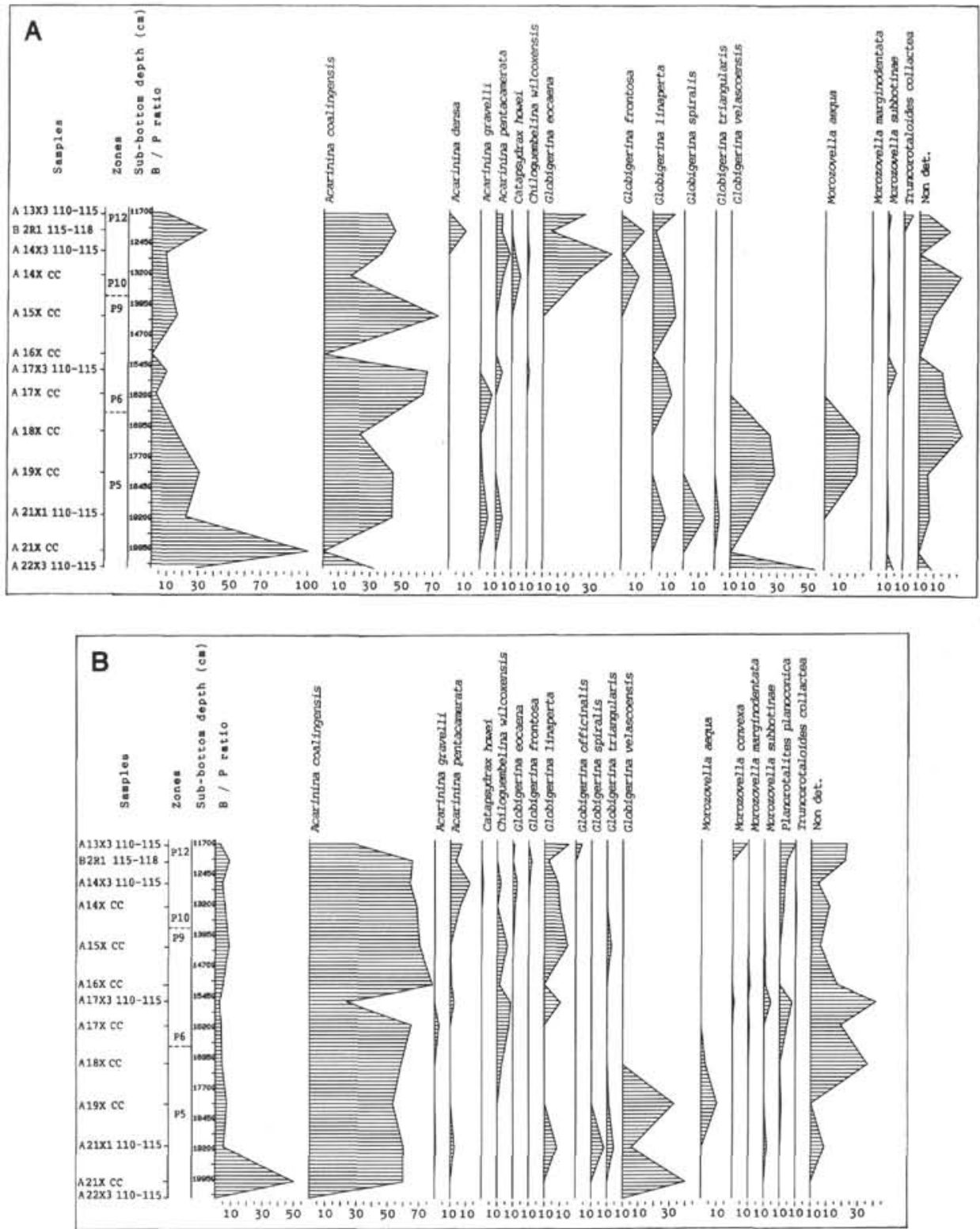

Figure 12. Frequency distribution of selected late Paleocene-middle Eocene planktonic foraminifers from Holes $752 \mathrm{~A}$ and $752 \mathrm{~B}$. Vertical scale 1:750. A. Specimens $>250 \mu \mathrm{m}$. B. Specimens $125-250 \mu \mathrm{m}$.

$110-115 \mathrm{~cm}$, as indicative for the top of this zone. Fauna composition otherwise changes very little.

The occurrence of Globigerina ampliapertura Bolli, 1957a in Samples 121-756C-5X-3, 140-145 cm, to 121-756C-6X-1, 110 $115 \mathrm{~cm},(115-131 \mathrm{mbsf})$ indicates Zone P20.

Sample 121-756C-6X-CC (130 mbsf) shows a much different fauna. Jenkinsella is absent, Globigerina praebulloides is replaced by G. eocaena Guembel, 1868, and G. angustiumbilicata and Globorotaloides suteri are much rarer. The few specimens of Globigerinatheka index (Finlay, 1939a), Hantkenina sp., and Turborotalia cunialensis (Toumarkine and Bolli, 1970) we consider reworked; thus, this sample is of earliest Oligocene age, Zone P19.

Samples 121-756C-7X-1, 110-115 cm, to 121-756C-8X-1, $110-115 \mathrm{~cm},(131-140.5 \mathrm{mbsf})$ contain Globigerinatheka index, G. subconglobata (Shutskaya, 1958), Hantkenina alabamensis Cushman, 1925a, H. brevispina Cushman, 1925a, and Turborotalia spp., indicating a latest Eocene age, Zones P17-18.

\section{Site 757 (Figs. 20 and 21 and Table 6)}

In Sample 121-757B-11H-2, 110-115 cm (94 mbsf), several species of Globigerinoides occur ( $G$. altiaperturus Bolli, 1957a, G. sacculifer (Brady, 1877), and G. trilobus (Reuss, 1850)), which clearly indicates an earliest Miocene age. Large Globigerina species are common, and Globigerina euapertura Jenkins, 1960 is remarkably rare.

We assign Sample 121-757B-11H-CC (101 mbsf) to the Oligocene-Miocene, Zones P22/N4, with abundant Fohsella kugleri (Bolli, 1957a) and Globigerinita glutinata (Egger, 1893).

The lack of marker species in Samples 121-757B-12H-2, 110 $115 \mathrm{~cm}$, to $121-757 \mathrm{~B}-13 \mathrm{H}-2,110-115 \mathrm{~cm},(103-113 \mathrm{mbs})$ makes separation of Zones P18 to P21 difficult. Globigerina euapertura dominates the $>250-\mu \mathrm{m}$ fractions (up to $70 \%$ ), and $G$. galavisi Bermúdez, 1960 and $G$. tripartita Koch, 1926 are common. The $125-250-\mu \mathrm{m}$ fractions are dominated by Globorotaloides suteri 

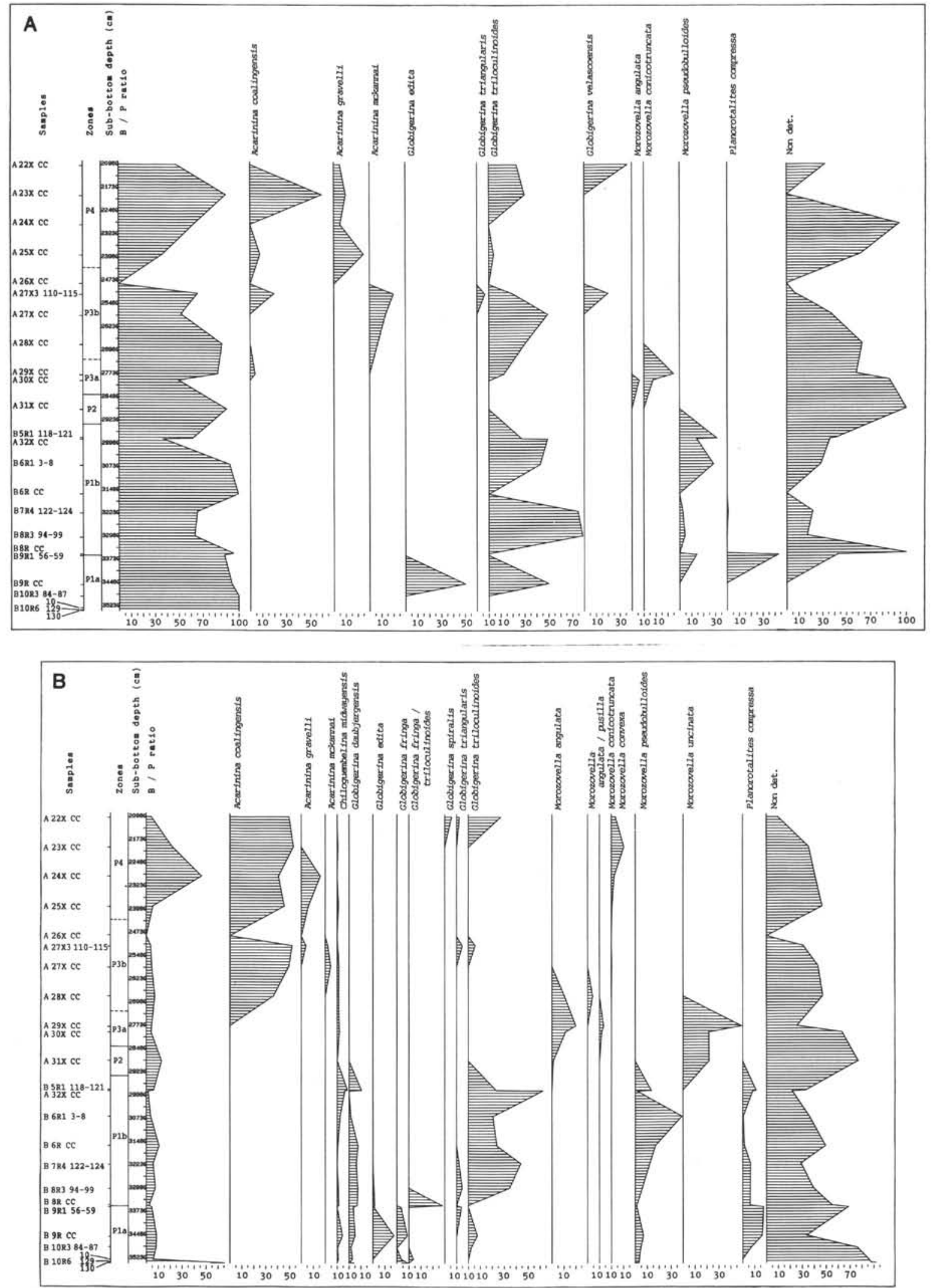

Figure 13. Frequency distribution of selected Paleocene planktonic foraminifers from Holes 752A and 752B. Vertical scale 1:750. A. Specimens $>250 \mu \mathrm{m}$. B. Specimens $125-250 \mu \mathrm{m}$. 

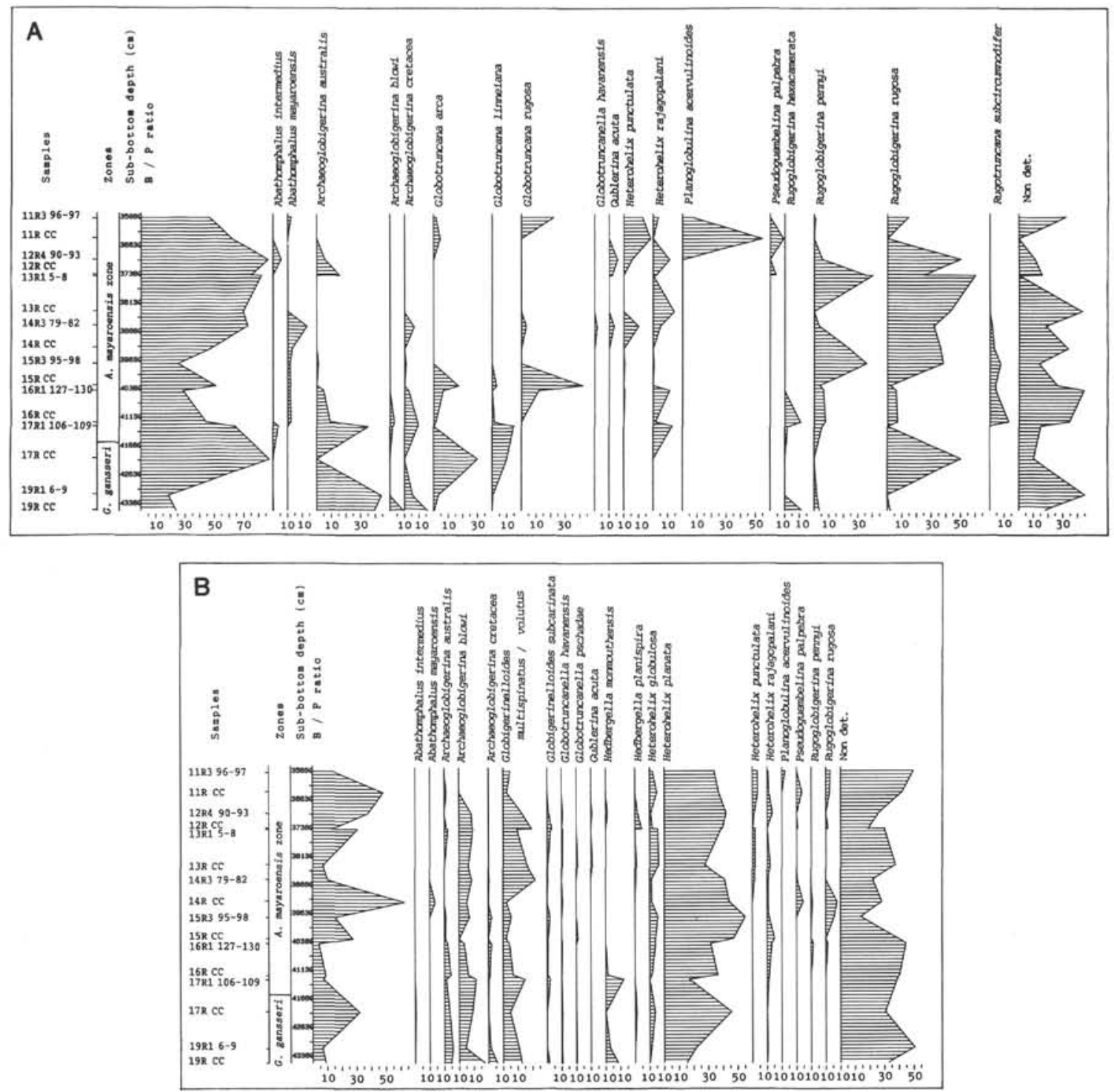

Figure 14. Frequency distribution of selected Cretaceous planktonic foraminifers from Hole 752B. Vertical scale 1:750. A. Specimens $>250 \mu \mathrm{m}$. B. Specimens $125-250 \mu \mathrm{m}$.

Bolli, 1957a and small Globigerina euapertura. Sample 121757B-13H-CC (120 mbsf) contains Globigerina eocaena Guembel, 1868 and Globigerinatheka sp. cf. G. index (Finlay, 1939a). This indicates a latest Eocene age.

Cribrohantkenina inflata (Howe, 1928), Hantkenina alabamensis Cushman, 1925a, Globigerinatheka subconglobata (Shutskaya, 1958), and Turborotalia sp. aff. cocoaensis/T. cunialensis, occurring in Sample 121-757B-14H-2, 110-115 cm (123 mbsf), indicate a late Eocene age. Poorly preserved late Eocene faunas (Zones P15 to P17), lacking marker species, were found in Samples $121-757 \mathrm{~B}-14 \mathrm{H}-2,110-115 \mathrm{~cm}$, to $121-757 \mathrm{~B}-15 \mathrm{H}-\mathrm{CC}$ (130-140 mbsf). G. euapertura is common, as are species of Globigerinatheka.

Acarinina species (notably $A$. densa (Cushman, 1925b)), indicating a middle Eocene age, are abundant to dominant in the faunas from Samples 121-757B-16H-CC to 121-757B-21X-CC (149-192 mbsf). Samples 121-757B-16H-CC and 121-757B$17 \mathrm{H}-\mathrm{CC}$ yielded Globigerinatheka subconglobata (Shutskaya, 1958) without Morozovella aragonensis (Nuttall, 1930), indicating Zones P12-14. Faunas from Samples 121-757B-18H-CC and
121-757B-19H-CC contain no G. subconglobata, but do contain $M$. aragonensis and Globigerina frontosa Subbotina, 1953, indicating Zones P10-11, early middle Eocene.

Morozovella caucasica (Glaessner, 1937), present in Samples 121-757B-20X-CC and 121-757B-21X-CC, and co-occurring with A. densa, indicates the base of Zone P10. Sample 121-757B$22 \mathrm{X}-\mathrm{CC}$ ( $202 \mathrm{mbsf})$ contains an undifferentiated fauna we assign to the early Eocene, Zones P7-8, with abundant $A$. coalingensis (Cushman and Hanna, 1927) and Morozovella convexa (Subbotina, 1953).

We assign Samples 121-757B-23X-CC and 121-757B-24X-3, $46-48 \mathrm{~cm},(212-215 \mathrm{mbsf})$ to Zone P6, earliest Eocene, based on the occurrence of Chiloguembelina wilcoxensis (Cushman and Ponton, 1932a), Globigerina velascoensis Cushman, 1925d, and Morozovella aequa (Cushman and Renz, 1942). Sample 121757B-23X-CC also contains abundant (27\%) Acarinina wilcoxensis (Cushman and Ponton, 1932a), a species not recorded from any other Leg 121 sample.

Remarkable is the occurrence of a species virtually indistinguishable from Clavatorella nicobarensis Srinivasan and Ken- 
Table 2. Distribution of additional species from Holes $752 \mathrm{~A}$ and $752 \mathrm{~B}$.

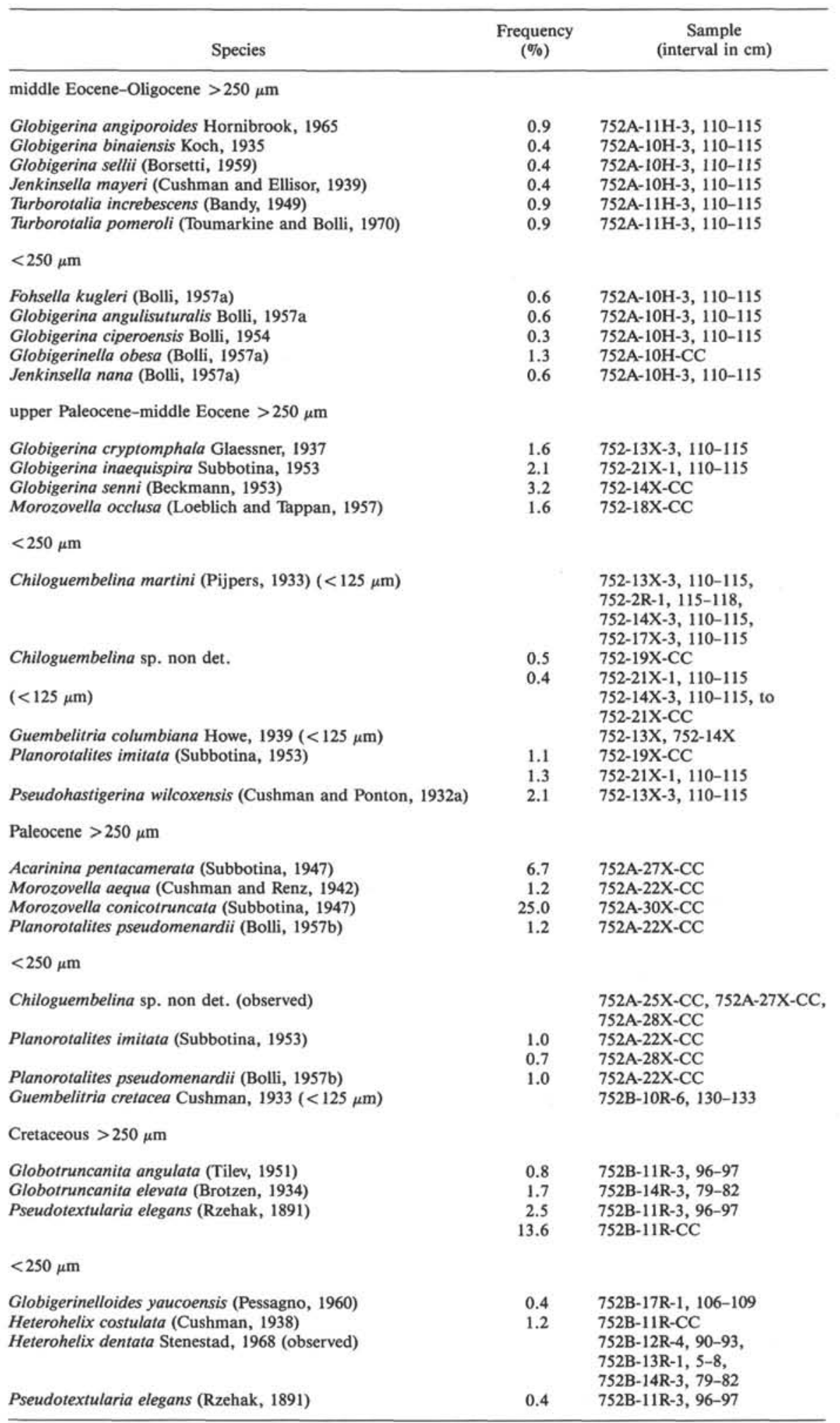

nett, 1976 in the 125-250- $\mu \mathrm{m}$ fraction of Samples 121-757B$11 \mathrm{H}-\mathrm{CC}(0.5 \%)$ and $121-757 \mathrm{~B}-12 \mathrm{H}-\mathrm{CC}(0.8 \%)$ (P1. 4, Figs. $8-$ 12). The range of this species is late Miocene to early Pliocene (N16-19). No other late Neogene species were found, so contamination is unlikely. The only species with which it may be confused are Protentella clavicamerata Jenkins, 1977 and Clavigerinella nazcaensis Quilty, 1976. P. clavicamerata is entirely planispiral, with a thin, pustulose wall, whereas the specimens found are initially trochospiral with a coarsely perforate wall. Small specimens of $C$. nazcaensis have a similar gross morphology, but have 

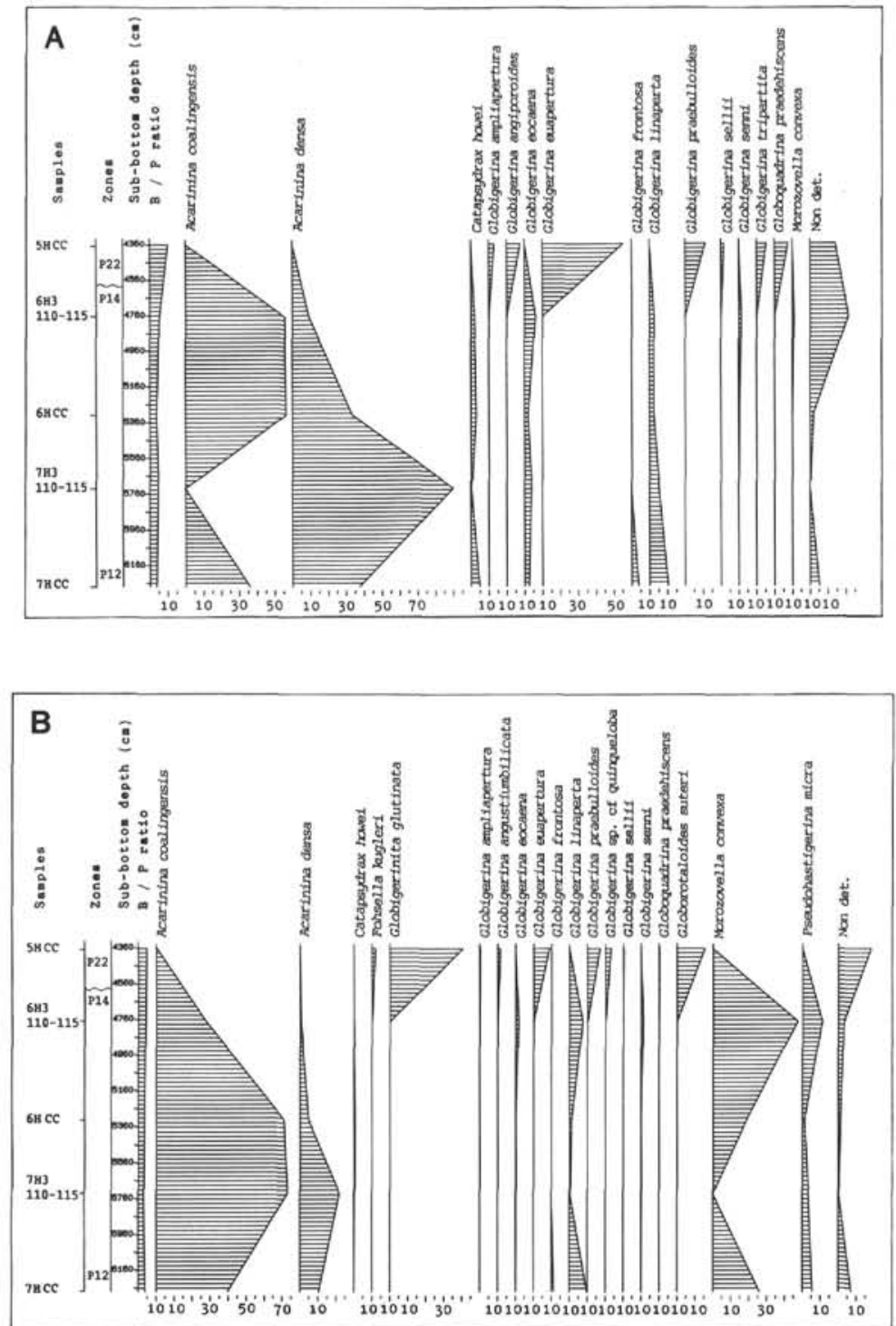

Figure 15. Frequency distribution of selected planktonic foraminifers from Hole 753A. Vertical scale 1:200. A. Specimens $>250 \mu \mathrm{m}$. B. Specimens $125-250 \mu \mathrm{m}$.

Table 3. Distribution of additional species from Hole 753A.

\begin{tabular}{|c|c|c|}
\hline Species & $\begin{array}{c}\text { Frequency } \\
(\%)\end{array}$ & $\begin{array}{l}\text { Core, section, } \\
\text { interval }(\mathrm{cm})\end{array}$ \\
\hline \multicolumn{3}{|l|}{$>250 \mu \mathrm{m}$} \\
\hline \multirow{2}{*}{$\begin{array}{l}\text { Globigerina galavisi Bermudez, } 1960 \\
\text { Jenkinsella continuosa (Blow, 1959) }\end{array}$} & 1.8 & $5 \mathrm{H}-\mathrm{CC}$ \\
\hline & 1.8 & $5 \mathrm{H}-\mathrm{CC}$ \\
\hline \multicolumn{3}{|l|}{$<250 \mu \mathrm{m}$} \\
\hline \multicolumn{2}{|l|}{ Chiloguembelina cubensis (Palmer, 1934) $(<125 \mu \mathrm{m})$} & $5 \mathrm{H}-\mathrm{CC}$ \\
\hline \multirow{2}{*}{ Chiloguembelina martini (Pijpers, 1933) $(<125 \mu \mathrm{m})$} & 0.3 & $7 \mathrm{H}-\mathrm{CC}$ \\
\hline & & $5 \mathrm{H}-\mathrm{CC}, 6 \mathrm{H}-\mathrm{CC}, 7 \mathrm{H}-\mathrm{CC}$ \\
\hline \multirow{2}{*}{$\begin{array}{l}\text { Globigerinella obesa (Bolli, 1957a) } \\
\text { Pseudohastigerina naguewichiensis (Myatliuk, 1950) }(<125 \mu \mathrm{m})\end{array}$} & 1.6 & $5 \mathrm{H}-\mathrm{CC}$ \\
\hline & & $6 \mathrm{H}-3,110-115,7 \mathrm{H}-\mathrm{CC}$ \\
\hline
\end{tabular}



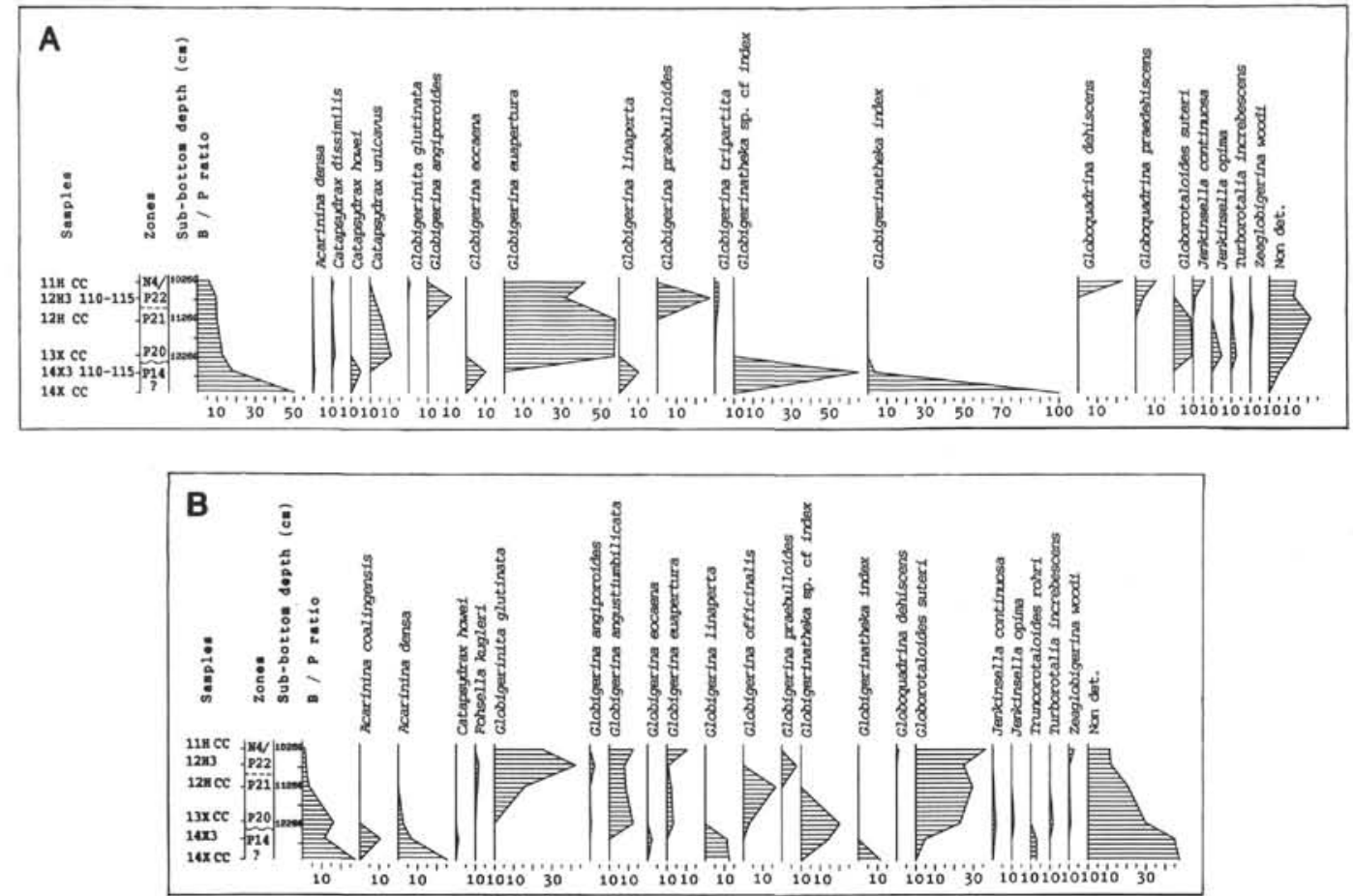

Figure 16. Frequency distribution of selected Paleogene planktonic foraminifers from Hole 754A. Vertical scale 1:1000. A. Specimens $>250 \mu \mathrm{m}$. B. Specimens $125-250 \mu \mathrm{m}$.

a thin, finely perforate wall. The same species was also found in upper Oligocene samples from Site 758.

\section{Site 758 (Figs. 22-25 and Table 7)}

Globigerina euapertura Jenkins, 1960 is dominant (20\% to $70 \%$, average $50 \%$ ) in all $>250-\mu \mathrm{m}$ Oligocene faunas. Other common Oligocene species are Catapsydrax dissimilis (Cushman and Bermúdez, 1937), C. unicavus Bolli, Loeblich, and Tappan, 1957, Globigerina galavisi Bermúdez, 1960, G. praebulloides Blow, 1959, G. sellii (Borsetti, 1959), and G. tripartita Koch, 1926.

Samples 121-758A-20X-CC to 121-758A-21X-2, 110-115 cm, (189-192 mbsf) contain several Globoquadrina species, indicating the Oligocene-Miocene (P22/N4).

Zone P22 (Samples 121-758A-21X-3, 110-115 cm, to 121$758 \mathrm{~A}-23 \mathrm{X}-5,110-115 \mathrm{~cm} ; 193-216 \mathrm{mbsf}$ ) is characterized by Jenkinsella mayeri (Cushman and Ellisor, 1939) and fairly common Globigerina binaiensis Koch, 1935 in the $>250-\mu \mathrm{m}$ fractions. Globigerina angustiumbilicata Bolli, 1957a and G. sp. cf. G. quinqueloba Natland, 1938 dominate the $125-250-\mu \mathrm{m}$ fractions. Fohsella kugleri (Bolli, 1957a) is common in the upper half of the zone and rare in the lower half.

Zone P21 (Samples 121-758A-23X-CC to 121-758A-25X-CC; $218-237 \mathrm{mbsf}$ ) is clearly identifiable from common Jenkinsella opima (Bolli, 1957a) in the $>250-\mu \mathrm{m}$ fractions. G. binaiensis is present but rare. In the $125-250-\mu \mathrm{m}$ fractions, $G$. angustiumbilicata is less abundant than before, and Globorotaloides suteri Bolli, 1957a has replaced $G$. sp. cf. G. quinqueloba. Jenkinsella nana (Bolli, 1957a) is common. Chiloguembelina cubensis (Palmer, 1934) is rare in the $125-250-\mu \mathrm{m}$ fractions, but common to dominant in the $<125-\mu \mathrm{m}$ fractions.

The lack of marker species (especially Globigerina ampliapertura Bolli, 1957a, Pseudohastigerina micra (Cole, 1927), and Turborotalia increbescens (Bandy, 1949)) makes separation of
Zones P19 and P20 (Samples 121-758A-26X-1, 110-115 cm, to 121-758A-26X-CC; 239-246 mbsf) difficult.

Eocene faunas occur only in samples from Section 121-758A$27 \mathrm{X}-\mathrm{CC}$ ( $257 \mathrm{mbsf})$ and are of poor quality. Acarinina spp. and Morozovella spp. indicate a (early) middle Eocene age, whereas the calcareous nannoplankton indicate a late Eocene age (J. J, Pospichal and P. Resiwati, pers. comm., 1990).

Samples 121-758A-28X-2, 115-120 cm, and 121-758A-28X-4, $115-120 \mathrm{~cm},(259-262 \mathrm{mbsf})$ contain well-preserved late Paleocene faunas, Zone P5, with many large species of Morozovella and Acarinina plus Globigerina velascoensis Cushman, $1925 \mathrm{~d}$.

The marker for Zone P4, Planorotalites pseudomenardii (Bolli, 1957b), occurs in Samples 121-758A-28X-CC to 121758A-30X-3, 115-120 cm (267-269 mbsf). Acarinina mckannai (White, 1928) occurs in the upper part of this zone; Globigerina triloculinoides Plummer, 1926 occurs in the lower part. Dominant in the $>250-\mu \mathrm{m}$ fraction of Sample 121-758A-30X-3, 115-120 $\mathrm{cm}$, is the large species Morozovella variospira (Belford, 1984). Intermediate forms connect this species to typical $M$. pseudobulloides in Samples 121-758A-31X-1, 115-120 cm, and 121-758A$31 \mathrm{X}-2,115-120 \mathrm{~cm}$.

Samples 121-758A-30X-CC and 121-758A-31X-1, 115-120 $\mathrm{cm},(286-287 \mathrm{mbsf}$ ) contain common Morozovella pusilla (Bolli, 1957 b) and Globigerina velascoensis, but no $P$. pseudomenardii (Bolli, 1957b), indicating Zone P3b.

Faunas indicating Zone P3a, characterized by the presence of $M$. angulata (White, 1928) and less common M. pusilla and lacking G. velascoensis, were found in Samples 121-758A-31X-2, $115-120 \mathrm{~cm}$, and 121-758A-31X-3, 115-120 cm (288-290 mbsf).

M. uncinata (Bolli, 1957b) and $M$. praecursoria (Morozova, 1957) occur commonly in Samples 121-758A-31X-4, 115-120 $\mathrm{cm}$, and 121-758A-31X-5, 115-120 cm, (291-293 mbsf) assigning them to Zone P2.

Sample 121-758A-31X-6, 115-120 cm (294 mbsf), contains rare $M$. trinidadensis (Bolli, 1957b), indicating Zone P1b. No 

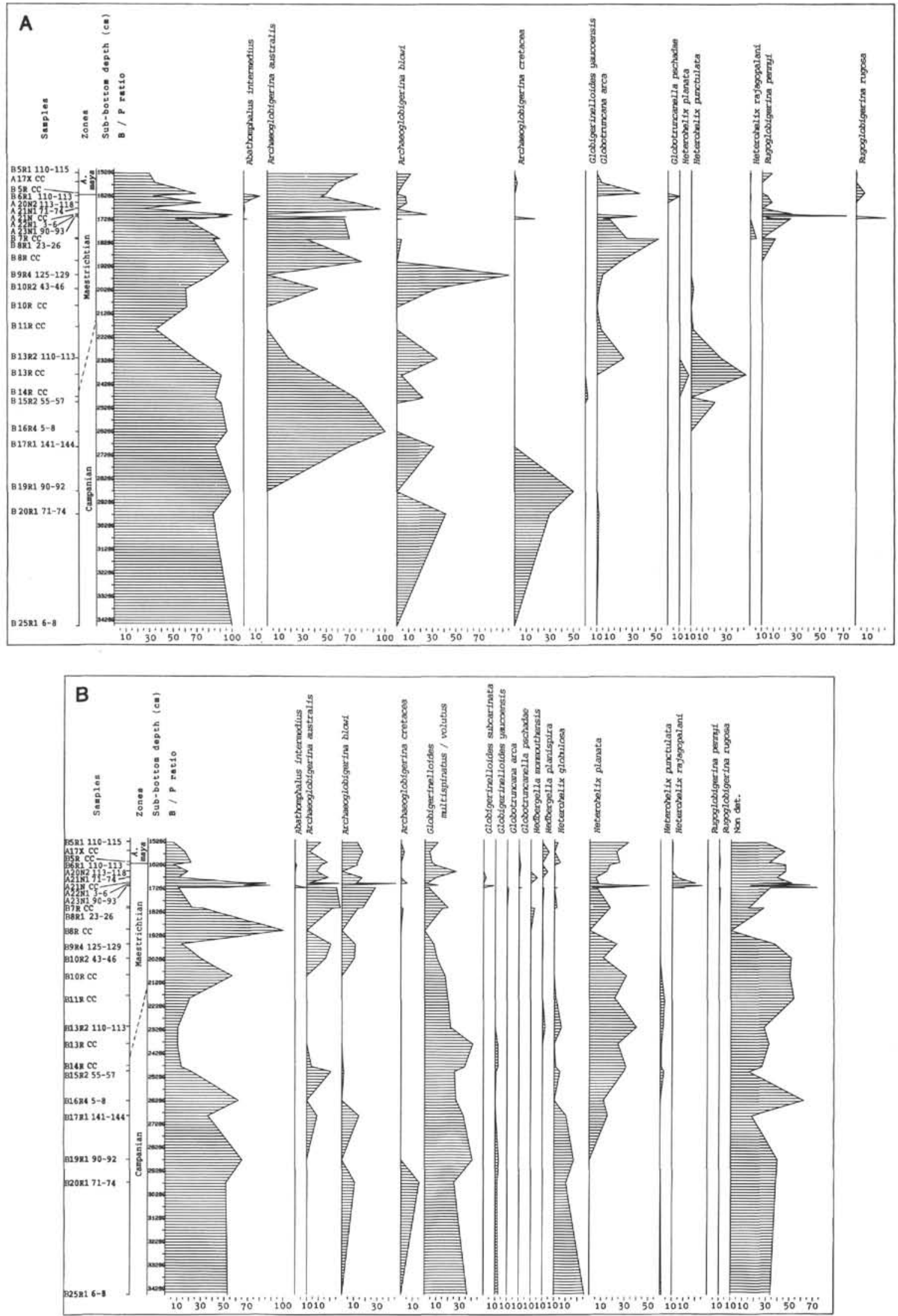

Figure 17. Frequency distribution of selected Cretaceous planktonic foraminifers from Holes 754A and 754B. Vertical scale 1:1000. A. Specimens $>250 \mu \mathrm{m}$. B. Specimens $125-250 \mu \mathrm{m}$. 
Table 4. Distribution of additional species from Holes 754A and 754B.

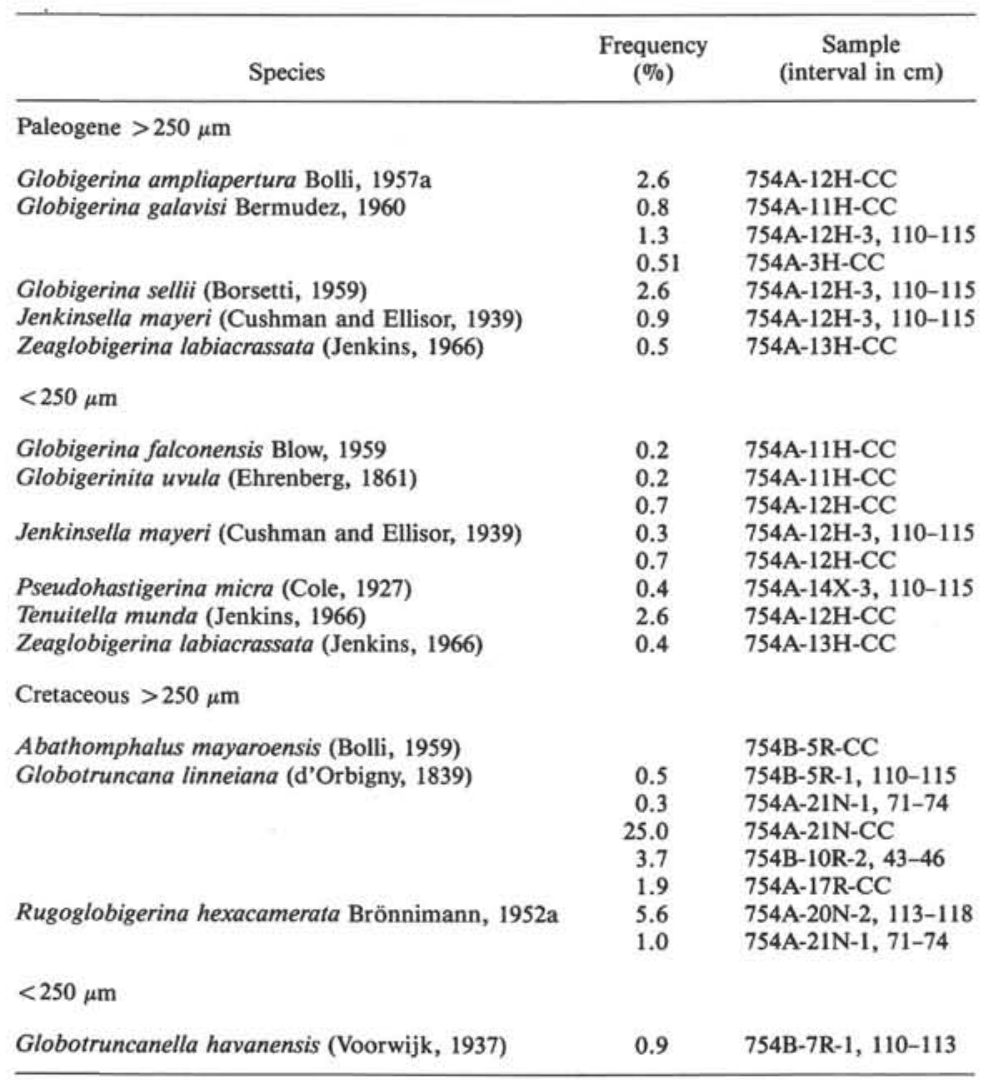

earliest Paleocene and latest Maestrichtian faunas were found, indicating an hiatus between 294 and 296 mbsf.

Samples 121-758A-31X-CC to 121-758A-33X-CC (296-312 mbsf) contain rare and primitive Abathomphalus mayaroensis (Bolli, 1951), indicating the base of the A. mayaroensis Zone. Sample 121-758A-31X-CC contains a diverse fauna with many species indicating warm to subtropical conditions, although most of these are extremely rare and only present outside of the count.

A. intermedius (Bolli, 1951) occurs in Samples 121-758A$34 \mathrm{X}-\mathrm{CC}$ and $121-758 \mathrm{~A}-35 \mathrm{X}-\mathrm{CC}(325-333 \mathrm{mbsf})$ without $A$. $\mathrm{ma}$ yaroensis, indicating a middle Maestrichtian age.

Below 333 mbsf, age-indicative species are almost entirely lacking. Samples 121-758A-36X-CC to 121-758A-40X-2, 97$100 \mathrm{~cm},(343-370 \mathrm{mbsf})$ contain a fauna with Globotruncana arca (Cushman, 1926), G. linneiana (d'Orbigny, 1839), Heterohelix punctulata (Cushman, 1938), Rugoglobigerina pennyi Brönnimann, 1952a, and Heterohelix rajagopalani (Govindan, 1972). We assign a Maestrichtian to Maestrichtian-Campanian age to these samples. Older samples, assigned a Campanian age, contain poorly preserved faunas dominated by Archaeoglobigerina blowi Pessagno, 1967 and A. cretacea (d'Orbigny, 1840) ( $>250-\mu \mathrm{m}$ fractions). The $125-250-\mu \mathrm{m}$ fractions contain $A$. blowi, Globigerinelloides multispinatus/G. volutus, Heterohelix globulosa (Ehrenberg, 1840), and H. planata (Cushman, 1938).

In the $125-250-\mu \mathrm{m}$ fraction of Samples 121-758A-21X-1, $110-115 \mathrm{~cm}$, and $121-758 \mathrm{~A}-21 \mathrm{X}-2,110-115 \mathrm{~cm},(1.3 \%$ and $0.4 \%$, respectively) a species indistinguishable from Clavatorella nicobarensis Srinivasan and Kennett, 1976 was found (see biostratigraphy for Site 757). Also, a planispiral species is present at very low frequency. This species resembles Protentella prolixa Lipps, 1964, which ranges from Zones N12 to N14 (middle Miocene).
One specimen (Pl. 5, Fig. 12) has a double aperture and resembles biapertural specimens of Globigerinelloides multispinatus (Lalicker, 1948). Reworking is unlikely, as we saw no other reworked foraminifers and the state of preservation is not different. Contamination is unlikely for the same reasons.

Throughout the Oligocene, we found a variety of Globigerina tripartita Koch, 1926. It has two to two and a half chambers in the final whorl, which together constitute $75 \%$ to $90 \%$ of the test size. As with $G$. tripartita, abortive, bullalike final chambers are common. This form, which we have named Globigerina sp. "bipartita," seems to indicate warm to subtropical conditions, as we found it at Site 758 only.

\section{CONCLUSIONS}

The recovered faunas clearly reflect the paleoclimate. Late Maestrichtian faunas contain many species that indicate a warm climate. However, most of these are extremely rare, so a temperate to subtropical climate must be assumed. Other samples from the Cretaceous are dominated by species of Heterohelix, Globigerinelloides, and Archaeoglobigerina, indicative of a cold, austral climate (Nederbragt, 1990; Huber, 1990). A subtropical climate during the Paleocene is indicated by the faunas from Site 758. The faunas from Site 752 indicate a more temperate climate, but selective preservation may have influenced the interpretation. All early and middle Eocene faunas indicate a more temperate climate, although the more tropical species may have been removed by dissolution. The late Eocene and Oligocene faunas show a clear differentiation, with faunas from the northernmost sites indicating a subtropical climate.

Quantitative sample and fauna processing provides much valuable data for relatively little extra work. Combined with informa- 

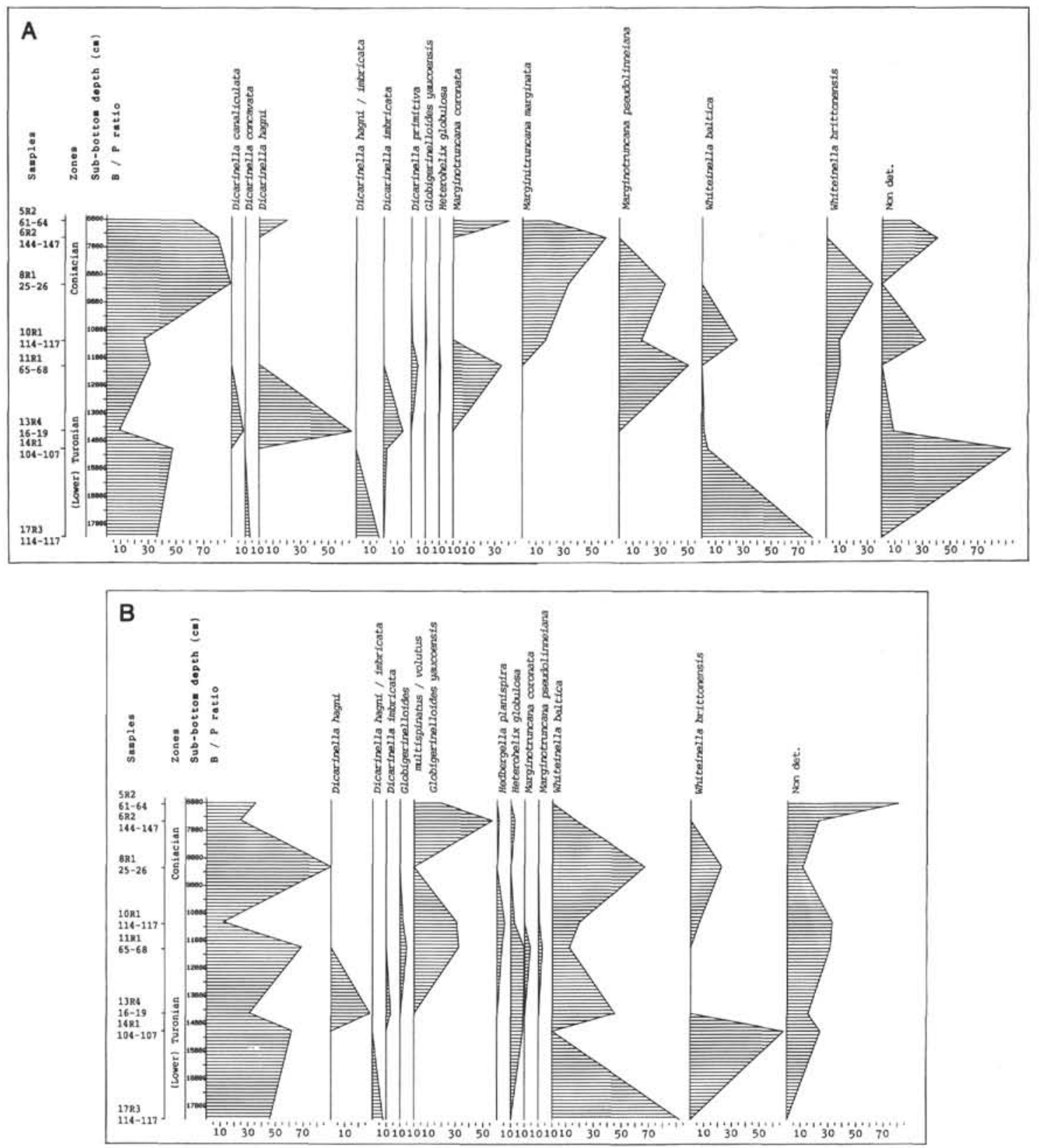

Figure 18. Frequency distribution of planktonic foraminifers from Hole 755A. Vertical scale 1:1000. A. Specimens $>250 \mu \mathrm{m}$. B. Specimens $125-250 \mu \mathrm{m}$.

tion on size distribution and preservation, important observations on fauna composition, paleoceanography, climate, and productivity can be made.

Although dating is not always as accurate as with fully tropical faunas, the zonations of Banner and Blow (1965) and Blow (1969) could generally be used, which facilitates comparison with other tropical areas. The zonations based on high-latitude faunas (e.g., Jenkins, 1966, 1985), are harder to apply, show poorer resolution, and are hard to compare with tropical zonations.

\section{SYSTEMATICS}

In this report, the Globigerinina are classified following Nederbragt (in press) for Cretaceous Heterohelicidae, Robaszynski and Caron (1979) and Robaszynski et al. (1984) for the Globotruncanidae, and Toumarkine and Luterbacher (1985), Bolli and Saunders (1985), and Kennett and Srinivasan (1983) for the Globigerinidae. Some modifications have been made. We classify all precursors of the angular-conical Morozovellids under Morozovella, although they are commonly named Subbotina (Berggren, 1977). The Paleogene Globigerinids are classified as Globigerina, not as Subbotina, because we feel that the differences between these are insufficient to warrant separate genera. Indeed, some species show a coarse, honeycombed wall pattern, but these intergrade with species with a Globigerina-type wall structure. Some species of Globigerina (e.g., G. euapertura) intergrade with species ascribed to Subbotina.

Kennett and Srinivasan's (1983) subgenera of Globorotalia have been given generic rank.

Some indistinct and biostratigraphically unimportant species of Globigerinelloides and Acarinina have been grouped together.

Species are illustrated to show variability, interpretation of species concept, or aberrant forms. 

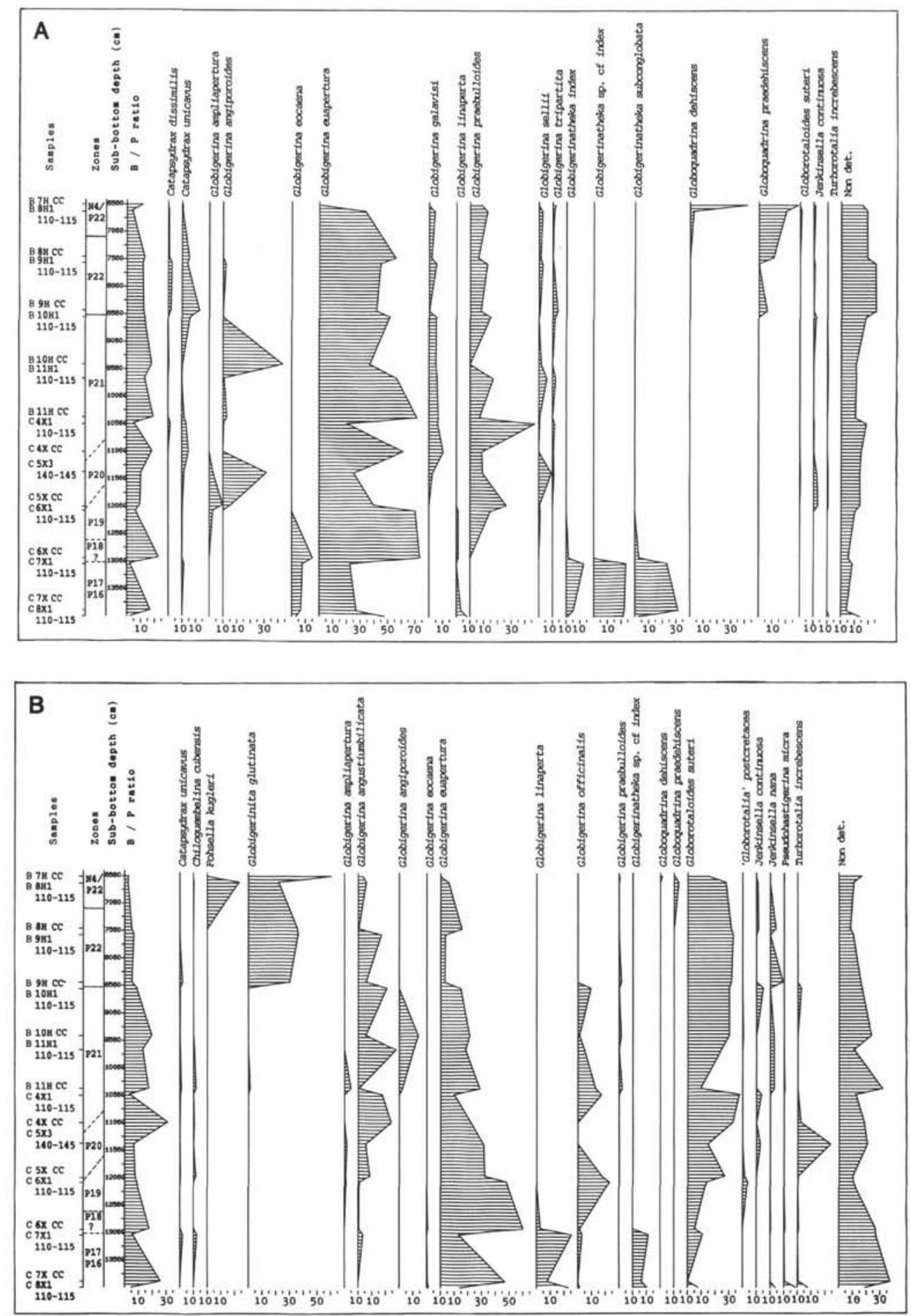

Figure 19. Frequency distribution of selected planktonic foraminifers from Holes 756B and 756C. Vertical scale 1:500. A. Specimens $>250 \mu \mathrm{m}$. B. Specimens $125-250 \mu \mathrm{m}$.

\section{Suborder GLOBIGERININA Delage and Herouard, 1896}

Family HETEROHELICIDAE Cushman, 1927c

Genus Chiloguembelina Loeblich and Tappan, 1956

Chiloguembelina cubensis

(Pl. 2, Figs. 1 and 2)

Guembelina cubensis Palmer, 1934, p. 74, figs. 1-6.

Remarks. Although rare in many lower and middle Oligocene 125 $250-\mu \mathrm{m}$ fractions, this species can be extremely abundant in the $<125-\mu \mathrm{m}$ fractions. In these sections its last occurrence seems to be just above the top of the J. opima Zone (P21), as it was found by Beckmann (1957) in the Caribbean. According to Palmer (1940), Renz (1948), Bermúdez (1949), Blow (1979), and Jenkins (1985), it may range into the upper Oligocene.

\section{Chiloguembelina martini}

Textularia martini Pijpers, 1933, p. 57, figs. 6-10.

Remarks. $C$. martini is usually rare in the $<125-\mu \mathrm{m}$ fractions of the middle Eocene from Site 757. 
Table 5. Distribution of additional species from Holes 756B and 756C.

\begin{tabular}{|c|c|c|}
\hline Species & $\begin{array}{c}\text { Frequency } \\
(\%)\end{array}$ & $\begin{array}{c}\text { Sample } \\
\text { (interval in } \mathrm{cm} \text { ) }\end{array}$ \\
\hline \multicolumn{3}{|l|}{$>250 \mu \mathrm{m}$} \\
\hline Globigerina gortanii (Borsetti, 1959) & 0.6 & $756 \mathrm{~B}-10 \mathrm{H}-1,110-115$ \\
\hline \multirow[t]{2}{*}{ Globigerinoides spp. } & 1.1 & 756B-7H-CC \\
\hline & 1.1 & $756 \mathrm{~B}-8 \mathrm{H}-1,110-115$ \\
\hline Hantkenina brevispina Cushman, 1925 a & 0.4 & $756 \mathrm{C}-6 \mathrm{X}-\mathrm{CC}$ \\
\hline Turborotalia cocoaensis/T. cunialensis & 0.4 & $756 C-7 X-1,110-115$ \\
\hline Turborotalia pomeroli (Toumarkine and Bolli, 1970) & 0.3 & $756 C-8 X-1,110-115$ \\
\hline \multicolumn{3}{|l|}{$<250 \mu \mathrm{m}$} \\
\hline Catapsydrax dissimilis (Cushman and Bermudez, 1937) & 0.4 & $756 \mathrm{~B}-10 \mathrm{H}-1,110-115$ \\
\hline Globigerina angulisuturalis Bolli, 1957a & 0.9 & $756 \mathrm{~B}-11 \mathrm{H}-\mathrm{CC}$ \\
\hline Globigerina ciperoensis Bolli, 1954 & 0.3 & $756 \mathrm{~B}-9 \mathrm{H}-\mathrm{CC}$ \\
\hline \multirow[t]{2}{*}{ Globigerina inaequispira Subbotina, 1953} & 0.4 & $756 \mathrm{C}-5 \mathrm{X}-\mathrm{CC}$ \\
\hline & 1.0 & $756 \mathrm{C}-6 \mathrm{X}-\mathrm{CC}$ \\
\hline Globigerina ouachitaensis Howe and Wallace, 1932 & 3.7 . & $756 C-8 X-1,110-115$ \\
\hline Globigerina sp. cf. quinqueloba Natland, 1938 & 2.3 & $756 \mathrm{~B}-8 \mathrm{H}-\mathrm{CC}$ \\
\hline Globigerinita uvula (Ehrenberg, 1861) & 0.2 & $756 \mathrm{~B}-8 \mathrm{H}-\mathrm{CC}$ \\
\hline Guembelitria columbiana Howe, $1939(<125 \mu \mathrm{m})$ & & $756 \mathrm{C}-4 \mathrm{X}-\mathrm{CC}$ \\
\hline Jenkinsella mayeri (Cushman and Ellisor, 1939) & 0.2 & $756 \mathrm{~B}-8 \mathrm{H}-\mathrm{CC}$ \\
\hline \multirow[t]{2}{*}{ Pseudohastigerina naguewichiensis (Myatliuk, 1950) } & 0.4 & $756 \mathrm{~B}-9 \mathrm{H}-1,110-115$ \\
\hline & 0.4 & $756 \mathrm{C}-5 \mathrm{X}-\mathrm{CC}$ \\
\hline Zeaglobigerina labiacrassata (Jenkins, 1966) & 0.9 & 756B-9H-CC \\
\hline
\end{tabular}
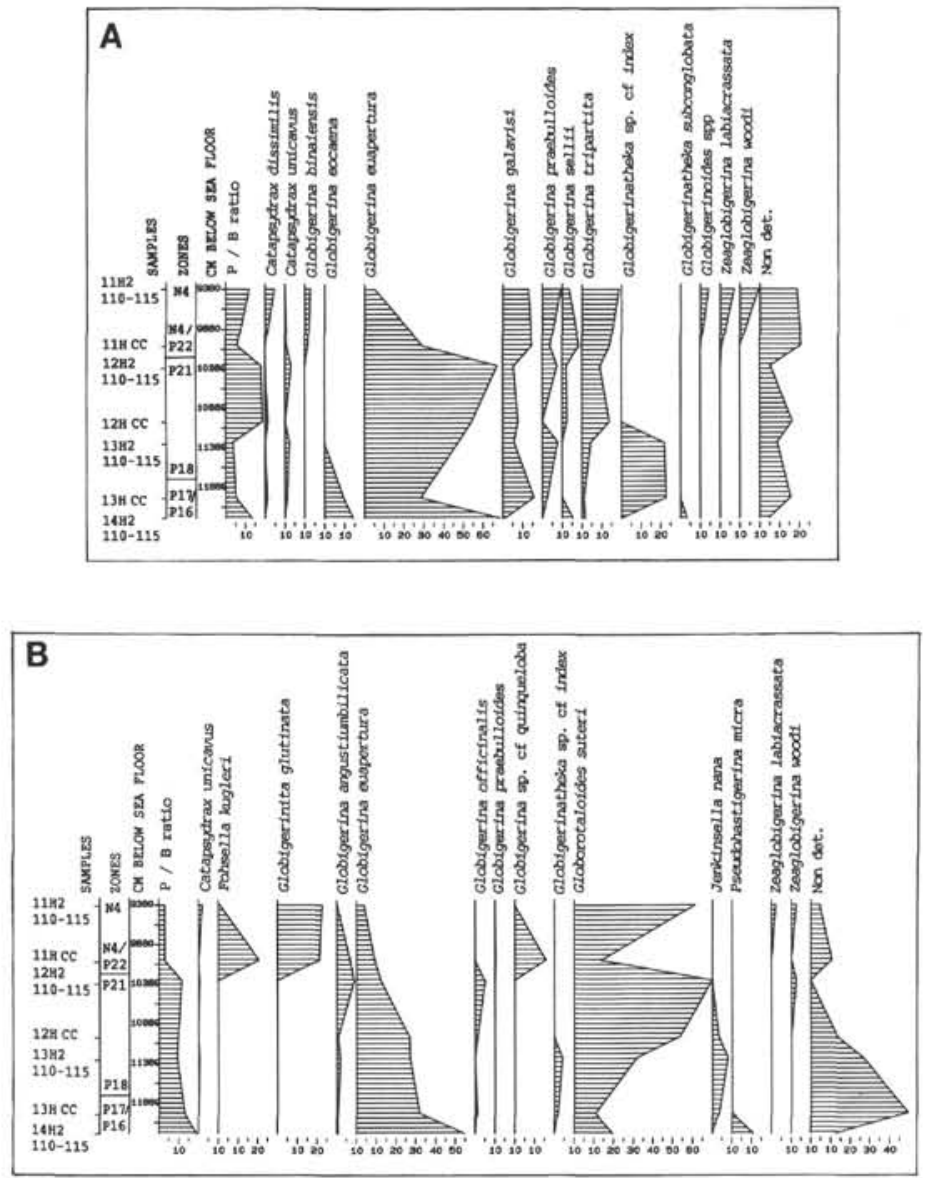

Figure 20. Frequency distribution of selected late Eocene-Oligocene planktonic foraminifers from Hole 757B. Vertical scale 1:500. A. Specimens $>250 \mu \mathrm{m}$. B. Specimens $125-250 \mu \mathrm{m}$. 

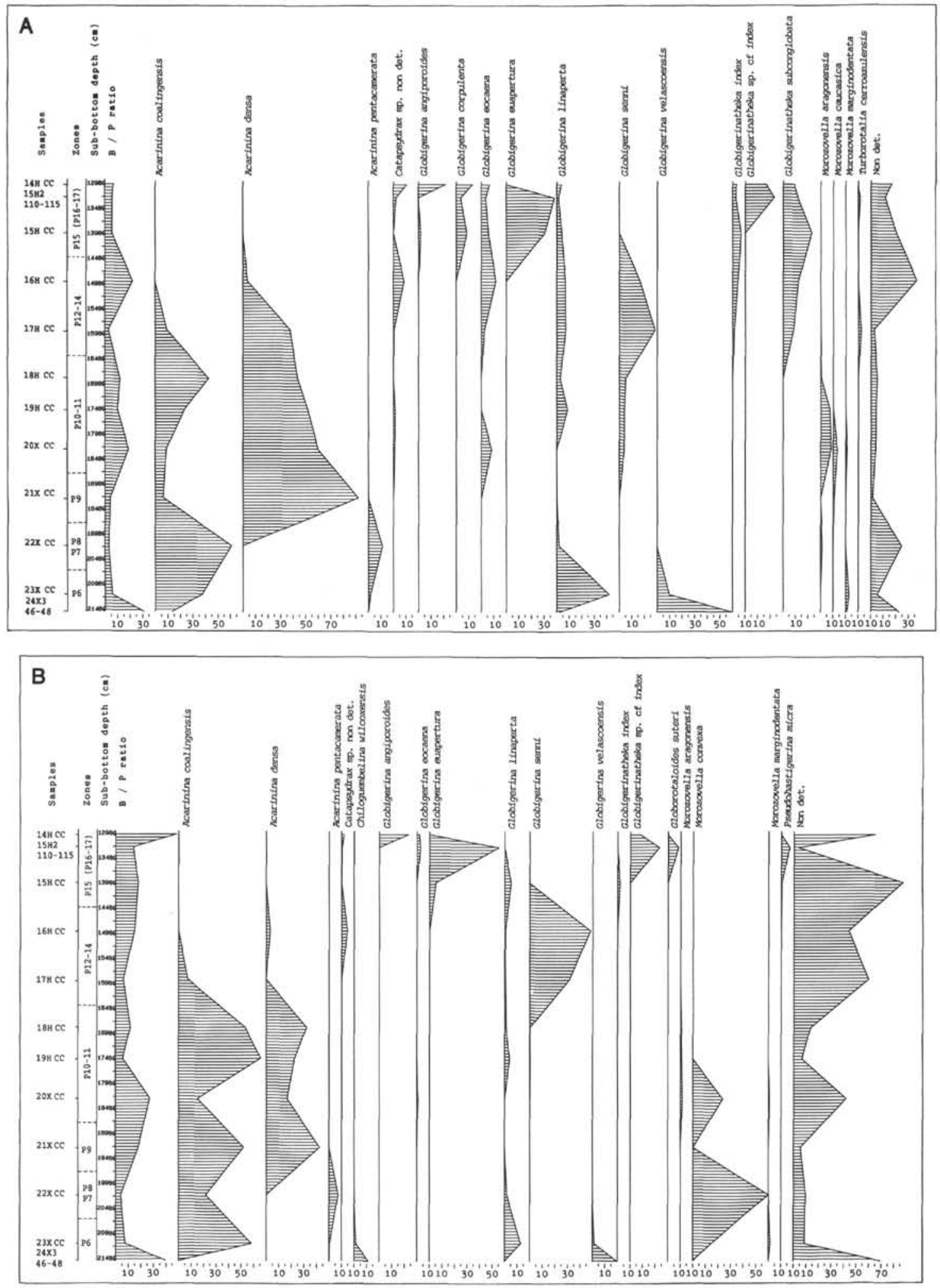

Figure 21. Frequency distribution of selected Eocene planktonic foraminifers from Hole 757B. Vertical scale 1:500. A. Specimens $>250 \mu \mathrm{m}$. B. Specimens $125-250 \mu \mathrm{m}$. 
Table 6. Distribution of additional species from Hole 757B.

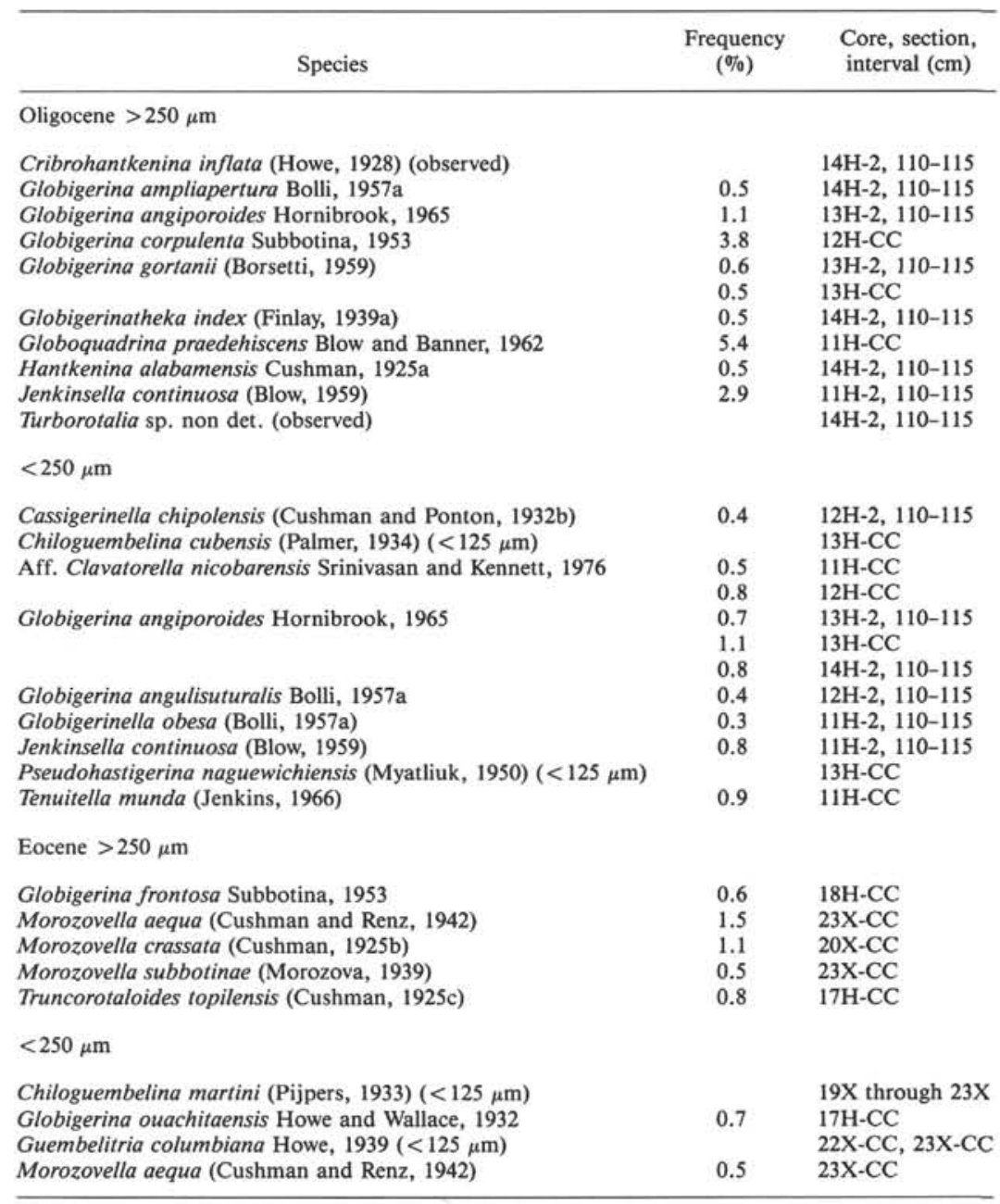

\section{Chiloguembelina midwayensis}

(Pl. 2, Figs. 3, 4, and 7)

Guembelina midwayensis Cushman, 1940, p. 65, pl. 11, fig. 15.

Remarks. This species is rare in the Paleocene at Sites 752 and 758.

\section{Chiloguembelina subtriangularis}

(PI. 2, Fig. 5)

Chiloguembelina subtriangularis Beckmann, 1957, p. 91, pl. 21, figs. 5a-5b, p. 85 , text fig. 15 , nos. $39-42$.

Remarks. This species is rare to very rare in $125-250-\mu \mathrm{m}$ fractions at Sites 752 and 758 , but abundant in some of the $<125-\mu \mathrm{m}$ fractions at Site 758.

\section{Chiloguembelina wilcoxensis}

Guembelina wilcoxensis Cushman and Ponton, 1932a, p. 66, pl. 8, figs. 16-17.

Remarks. $C$. wilcoxensis is usually rare in upper Paleocene-lower Eocene samples from Sites 752 and 757.

\section{Genus Gublerina Kikoine, 1948}

\section{Gublerina acuta}

Gublerina acuta robusta de Klasz, 1953b, p. 247, figs. 4a-5b.

Remarks. This species is rare in the upper Maestrichtian at Sites 752 and 758 . This local range is paleoenvironmentally controlled, as elsewhere the species is known to range throughout the Maestrichtian.

\section{Genus Guembelitria Cushman, 1933 \\ Guembelitria columbiana \\ (Pl. 2, Fig. 6)}

Guembelitria columbiana Howe, 1939, p. 62, pl. 8, figs. 12-13.

Remarks. $G$. columbiana occurs in the $<125-\mu \mathrm{m}$ fraction of several Eocene samples. Usually it is rare and extremely small. It is most common at Site 753, where it occurs throughout the middle Eocene. Usually, it is found in the mid-middle Eocene (Kroon and Nederbragt, in press). This species can be so extremely small that it will pass through the commonly used $63-\mu \mathrm{m}$ sieves.

\section{Guembelitria cretacea}

Guembelitria cretacea Cushman, 1933, p. 37, pl. 4, figs. 12a-12b.

Remarks. We observed a single, poorly preserved specimen in the $<125-\mu \mathrm{m}$ fraction of Sample 121-752B-10R-6, 130-133 cm.

\section{Genus Heterohelix Ehrenberg, 1843 \\ Heterohelix costulata}

Guembelina costulata Cushman, 1938, p. 16-17, pl. 3, figs. 7a-9.

Remarks. $H$. costulata is extremely rare in the upper Maestrichtian at Site 752. Its local range is paleoenvironmentally controlled, and elsewhere it is known to range from the middle Campanian to the top of the Maestrichtian. 

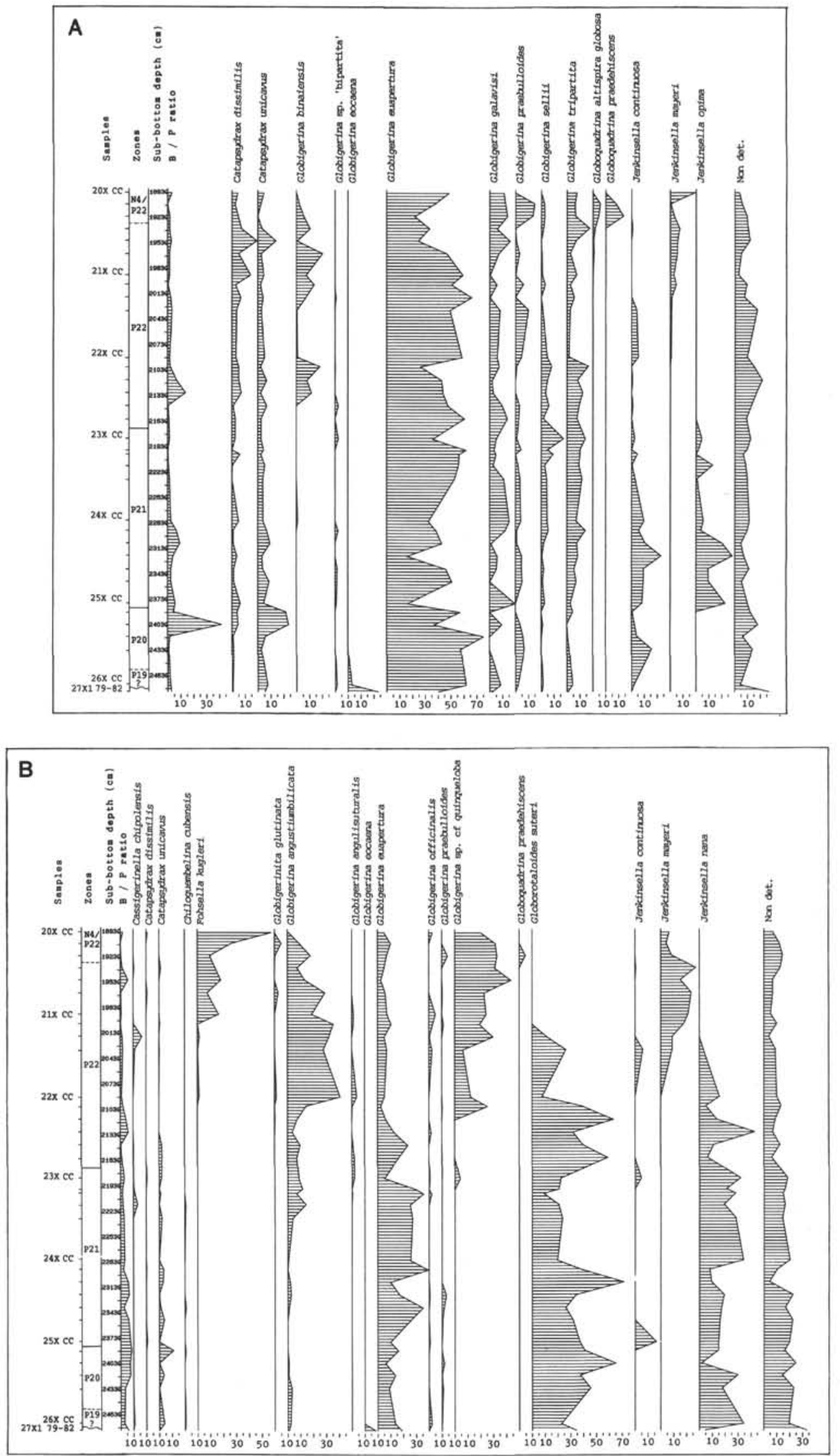

Figure 22. Frequency distribution of selected Oligocene planktonic foraminifers from Hole 758A. Vertical scale 1:300. A. Specimens $>250 \mu \mathrm{m}$. B. Specimens $125-250 \mu \mathrm{m}$. 

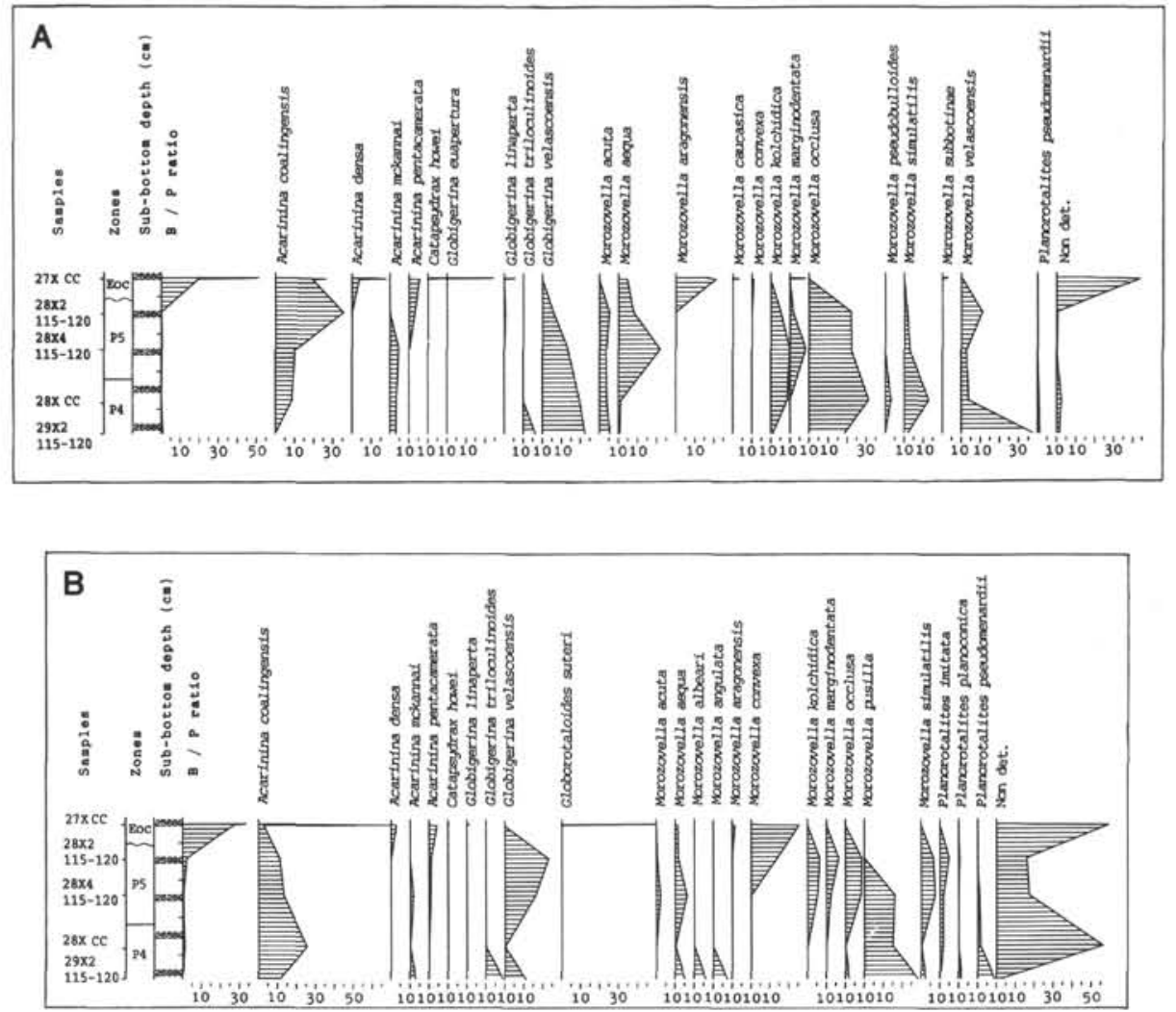

Figure 23. Frequency distribution of selected late Paleocene-Eocene planktonic foraminifers from Hole 758A. Vertical scale 1:300. A. Specimens $>250 \mu \mathrm{m}$. B. Specimens $125-250 \mu \mathrm{m}$.

\section{Heterohelix dentata}

Heterohelix dentata Stenestad, 1968, p. 67-68, pl. 1, figs. 3-6, 8-9.

Remarks. This species is extremely rare in the upper Maestrichtian at Sites 752 and 758. As it is known to range from the upper Campanian to the upper Maestrichtian, its local range is paleoenvironmentally controlled.

\section{Heterohelix globulosa}

Textularia globulosa Ehrenberg, 1840, p. 135, pl. 4, figs. 2, 4-5, 7-8.

Remarks. Intermediate forms with the more compressed $H$. planato (Cushman, 1938) are common. This species is rare in all Maestrichtian samples, and more common in older samples.

\section{Heterohelix planata}

Guembelina planata Cushman, 1938, p. 12-13, pl. 2, figs. 13a-14.

Remarks. Intermediate forms with $H$. globulosa (Ehrenberg, 1840), which has more globular chambers, and $H$. rajagopalani (Govindan, 1972 ), which is ornamented, are common. It typically dominates the $125-250-\mu \mathrm{m}$ fraction of the pre-Maestrichtian samples. Although the species has a conspicuous first appearance within the Campanian at Site 754 , it is known to range from the lowermost Campanian to the Maestrichtian.

\section{Heterohelix punctulata}

Guembelina punctulata Cushman, 1938, p. 13, pl. 2, figs. 15-16b.

Remarks. $H$. punctulata is usually rare but widespread in the Maestrichtian and Campanian samples. Elsewhere, it is most abundant in the upper Campanian (Pessagno, 1967).

\section{Heterohelix rajagopalani}

Gublerina rajagopalani Govindan, 1972, p. 170, pl. 2, figs. 1-5.
Remarks. Intermediate forms with the unornamented $H$. planata (Cushman, 1938) are common. Occurring from the middle Maestrichtian upward, its local range is paleoenvironmentally controlled, as elsewhere it is known to occur in the lower Maestrichtian as well.

\section{Heterohelix semicostata}

Gublerina semicostata Cushman, 1938, p. 16, pl. 3, figs. 6a-6b.

Remarks. H. semicostata is extremely rare when present in the upper Maestrichtian of Site 758.

\section{Genus Planoglobulina Cushman, 1927c Planoglobulina acervulinoides}

Guembelina acervulinoides Egger, 1899, p. 35, pl. 14, figs. $20-22$ (non figs. 14-18).

Remarks. P. acervulinoides is rare to common in the A. mayaroensis Zone at Sites 752 and 758.

\section{Planoglobulina multicamerata}

Ventilabrella multicamerata de Klasz, 1953a, p. 230, pl. 5, figs. 1a-1b.

Remarks. This species was found outside of the count in Sample 121-758B-31X-CC.

\section{Planoglobulina riograndensis}

Ventilabrella riograndensis Martin, 1972, p. 88-89, pl. 2, figs. 1-4b.

Remarks. P. riograndensis was found outside of the count in Sample 121-758B-31X-CC.

\section{Genus Pseudoguembelina Brönnimann and Brown, 1953} Pseudoguembelina costulata

Guembelina costulata Cushman, 1946, p. 108, pl. 46, figs. 10a-10b. 

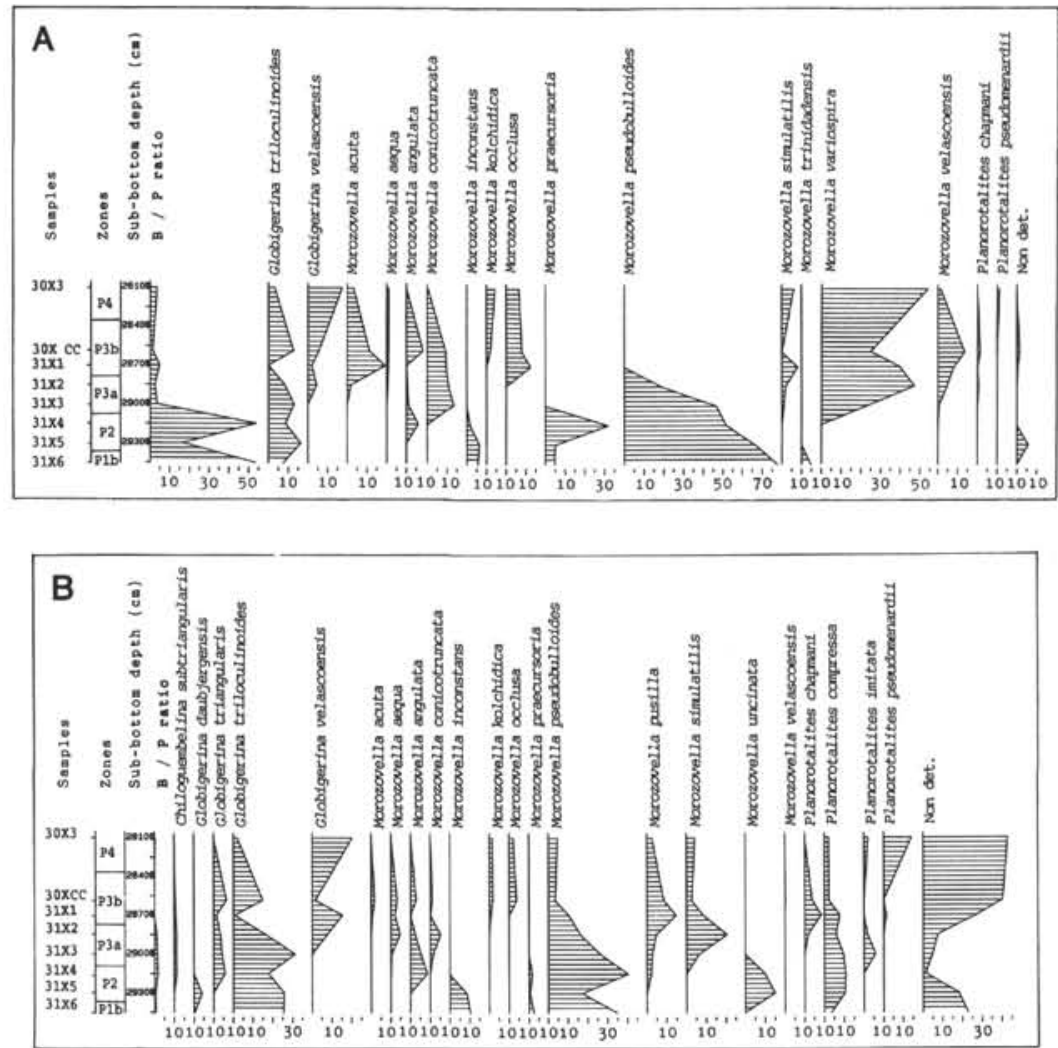

Figure 24. Frequency distribution of selected Paleocene planktonic foraminifers from Hole 758A. Vertical scale 1:300. A. Specimens $>250 \mu \mathrm{m}$. B. Specimens $125-250 \mu \mathrm{m}$.

Remarks. This species is extremely rare in the upper Maestrichtian at Site 758.

\section{Pseudoguembelina palpebra}

Pseudoguembelina palpebra Brönnimann and Brown, 1953, p. 155, text figs. $9 \mathrm{a}-10 \mathrm{~b}$.

Remarks. This species is usually rare; we found it in the upper Maestrichtian at Site 758. Elsewhere it is also known from the middle Maestrichtian.

\section{Genus Pseudotextularia Rzehak, 1891}

\section{Pseudotextularia elegans}

Cuneolina elegans Rzehak, 1891, p. 4.

Remarks. $P$. elegans is rare in the upper Maestrichtian. As it is known elsewhere from the lower and middle Maestrichtian, its local range is paleoenvironmentally controlled.

\section{Pseudotextularia intermedia}

Pseudotextularia intermedia de Klasz, 1953a, p. 231, pl. 5, figs. 2a-2c.

Remarks. $P$. intermedia is extremely rare in the upper Maestrichtian at Site 758.

\section{Pseudotextularia nuttalli}

Guembelina nuttalli Voorwijk, 1937, p. 192, pl. 2, figs. 1-9.

Remarks. Rare specimens probably referable to this species (A. J. Nederbragt, pers. comm., 1990) occur in the upper Maestrichtian at Site 758.

Genus Racemiguembelina Montanaro Gallitelli, 1957 Racemiguembelina fructicosa

Guembelina fructicosa Egger, 1899, p. 36, pl. 14, figs. 8-9, not figs. 24-26.
Remarks. $R$. fructicosa occurs outside of the count in Sample 121758B-31X-CC.

\author{
Family GLOBOTRUNCANIDAE Brotzen, 1942 \\ Genus Abathomphalus Bolli, Loeblich, and Tappan, 1957 \\ Abathomphalus mayaroensis
}

Globotruncana mayaroensis Bolli, 1951, p. 190, 198, pl. 35, figs. 10-12.

Remarks. Rare and usually rather small, with a weakly developed second keel, the encountered A. mayaroensis specimens are intermediate with A. intermedius (Bolli, 1951) at Sites 752, 754, and 758.

\section{Abathomphalus intermedius}

Globotruncana intermedia Bolli, 1951, p. 198, pl. 35, figs. 7-9.

Remarks. Usually rare, commonly small, and with the second keel typically weakly developed, the $A$. intermedius that were found are intermediate with Globotruncanella pschadae (Keller, 1946).

$$
\begin{gathered}
\text { Genus Archaeoglobigerina Pessagno, } 1967 \\
\text { Archaeoglobigerina australis } \\
\text { (Pl. 1, Figs. 1-3) }
\end{gathered}
$$

Archaeoglobigerina australis Huber, 1990, pl. 2, figs. 11-13, pl. 3, figs. 1-7.

Remarks. The presence of many forms intermediate with Rugoglobigerina pennyi Brönnimann, 1952a shows the close affinities of Archaeoglobigerina with Rugoglobigerina. We consider it to be the unornamented (high latitude?) equivalent of $R$. pennyi.

\section{Archaeoglobigerina blowi}

Archaeoglobigerina blowi Pessagno, 1967, p. 316, pl. 59, figs. 5-7.

Remarks. Intermediate forms with $R$. rugosa (Plummer, 1926) occur in the Maestrichtian, but the species also occurs in older samples. The 

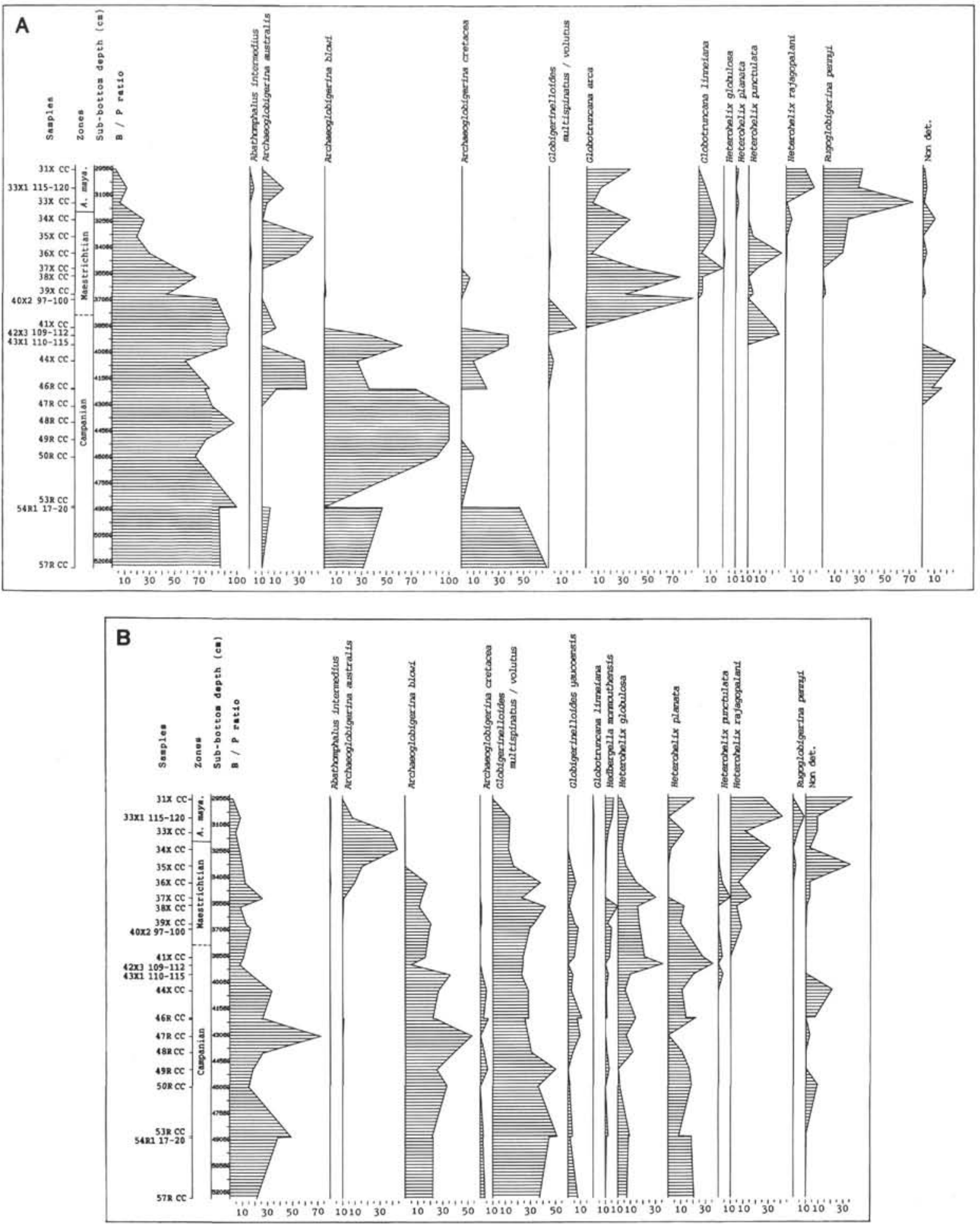

Figure 25. Frequency distribution of selected Cretaceous planktonic foraminifers from Hole 758A. Vertical scale 1:1500. Note scale difference with previous figures. A. Specimens $>250 \mu \mathrm{m}$. B. Specimens $125-250 \mu \mathrm{m}$.

commonly dominating occurrence in the $125-250-\mu \mathrm{m}$ fractions is due to the "dumping" of small Archaeoglobigerina forms into this species.

\section{Archaeoglobigerina bosquensis}

Archaeoglobigerina bosquensis Pessagno, 1967, p. 316-317, pl. 60, figs. 10-12.

Remarks. If present, A. bosquensis has been counted as A. australis Huber, 1990.

\section{Archaeoglobigerina cretacea}

(PI. 1, Figs. 4 and 5)

Globigerina cretacea d'Orbigny, 1840, p. 34, pl. 3, figs. 12-14.

Remarks. Higher trochospiral forms, which are intermediate between this species and A. australis, are common. In the Maestrichtian, intermediate forms with Rugoglobigerina hexacamerata Brönnimann, 1952a also occur. The species is most common in Campanian samples. 
Genus Dicarinella Porthauld, 1970

Dicarinella canaliculata

Rosalina canaliculata Reuss, 1854 , p. 70 , pl. 26 , figs. 4a-4b.

Remarks. This species occurs only in Sample 121-755A-13R-4, $16-19 \mathrm{~cm}$.

\section{Dicarinella hagni}

Praeglobotruncana hagni Scheibnerova, 1962, p. 219, figs. 6a-6c.

Remarks. Forms intermediate between this species and $D$. imbricata (Mornod, 1949-1950) occur in Sample 121-755A-17R-3, 114-117 cm.

\section{Dicarinella imbricata}

Globotruncana (Globotruncana) imbricata Mornod, 1949-1950, p. 589-590, fig. 5 (IIIa-IIId).

Remarks. See D. hagni (Scheibnerova, 1962).

Genus Globotruncana Cushman, 1927a

Globotruncana arca

Pulvinulina arca Cushman, 1926, p. 23, pl. 3, figs. 1a-1c.

Remarks. Forms intermediate between this species and $G$. rugosa (Marie, 1941) occur. Its local range is paleoenvironmentally controlled, and elsewhere it ranges from the Santonian to the middle Maestrichtian. We found it in the middle and also the upper Maestrichtian.

\section{Globotruncana linneiana}

Rosalina linneiana d'Orbigny, 1839, p. 101, pl. 5, figs. 10-12.

Globotruncana orientalis

Globotruncana orientalis El Naggar, 1966, p. 125, pl. 12, figs. 4a-4d.

Remarks. G. orientalis occurs in the Maestrichtian at Site 758 only, but is abundant in some $>250-\mu \mathrm{m}$ fractions.

\section{Globotruncana rosetta}

Globigerina rosetta Carsey, 1926, p. 44, pl. 5, figs. 3a-3b.

Remarks. G. rosetta was found in Sample 121-758B-31X-CC only.

\section{Globotruncana rugosa}

Rosalinella rugosa Marie, 1941, p. 240, pl. 36, fig 3. 340a-340c.

Remarks. See G. arca (Cushman, 1926), of which it is a high-latitude variant.

\section{Globotruncana ventricosa}

Globotruncana canaliculata var. ventricosa White, 1928, p. 284, pl. 38, figs. $3 a-3 c$.

Remarks. This species was found only in the $>250-\mu \mathrm{m}$ fraction of Samples 121-758B-31X-CC and 121-758B-39X-CC.

\section{Genus Globotruncanella Reiss, 1957 \\ Globotruncanella havanensis}

Globotruncana havanensis Voorwijk, 1937, p. 195, pl. 1, figs. 25-26, 29. Redescribed and refigured by van Hinte (1963), pl. 12, figs. 1a-1c.

Remarks. G. havanensis is widespread but usually rare.

\section{Globotruncanella petaloidea}

Globotruncana (Rugoglobigerina) petaloidea subsp. petaloidea Gandolfi, 1955, p. 52, pl. 3, figs. 13a-13c.

Remarks. G. petaloidea is rare in the Maestrichtian at Site 758.

Globotruncanella pschadae

Globorotalia pschadae Keller, 1946, p. 99, pl. 2, figs. 4-6.

Remarks. G. pschadae is widespread but usually rare.
Genus Globotruncanita Reiss, 1957

Globotruncanita angulata

Globotruncana lugeoni Tilev, var. angulata Tilev, 1951, p. 46, pl. 3, figs. 1a-1c, 13a-13c.

Remarks. We observed a single specimen in Sample 121-752B$11 \mathrm{R}-3,96-97 \mathrm{~cm}$.

\section{Globotruncanita stuarti}

Rosalina stuarti de Lapparent, 1918, p. 11, pl. 1, figs. 5-7, pl. 4 (p. 12), pl. 5 (p. 13).

Remarks. G. stuarti occurs outside of the count in Sample 121758B-31X-CC.

\section{Globotruncanita stuartiformis}

Globotruncana (Globotruncana) elevata Brotzen, subsp. stuartiformis Dalbiez, 1955, p. 169, text figs. 10a-10c.

Remarks. This species occurs outside of the count in Sample 121758B-31X-CC.

Genus Hedbergella Brönnimann and Brown, 1958

$$
\text { Hedbergella holmdelensis }
$$

Hedbergella holmdelensis Olsson, 1964, p. 160, pl. 1, figs. 2a-2c.

Remarks. This species is very rare and we included it in the count of H. monmouthensis (Olsson, 1960).

\section{Hedbergella monmouthensis}

Globorotalia monmouthensis Olsson, 1960, p. 47, pl. 9, figs. 22-24.

Remarks. See H. holmdelensis Olsson, 1964.

$$
\text { Hedbergella planispira }
$$

(Pl. 1, Figs. 6-8)

Globigerina planispira Tappan, 1940, p. 122, pl. 9, figs. 12a-12c.

Remarks. Although the range of this species is reported as TuronianCenomanian, small specimens indistinguishable from $H$. planispira occur in many samples of Maestrichtian and Campanian age.

\section{Genus Marginotruncana Hofker, 1956}

\section{Marginotruncana coronata}

Globotruncana lapparenti Brotzen, subsp. coronata Bolli, 1945, p. 233, text fig. 1, nos. 21-22, pl. 9, figs. 14-15.

\section{Marginotruncana marginata}

Rosalina marginata Reuss, 1854, p. 36, pl. 13, figs. 18a-18b.

$$
\text { Marginotruncana pseudolinneiana }
$$

Marginotruncana pseudolinneiana Pessagno, 1967, p. 310, pl. 65, figs. 24-27, pl. 76, figs. 1-3.

Genus Rosita Robaszynski, Caron, Gonzalez Donoso, and Wonders, 1984

\section{Rosita walfischensis}

Globotruncana walfischensis Todd, 1970, p. 153, pl. 5, figs. 8a-8b.

Remarks. $R$. walfischensis was found in Sample 121-758B-31X-CC only.

\section{Genus Rugoglobigerina Brönnimann, 1952a \\ Rugoglobigerina hexacamerata}

Rugoglobigerina (Rugoglobigerina) reicheli hexacamerata Brönnimann, 1952a, p. 23, pl. 2, figs. 10-12.

Remarks. $R$. hexacamerata occurs in the Maestrichtian and is usually rare. Intermediate forms with its ancestor, Archaeoglobigerina cretacea (d'Orbigny, 1840), and its descendant, Rugotruncana subcircumnodifer (Gandolfi, 1955), occur. 
Table 7. Distribution of additional species from Hole 758A.

\begin{tabular}{|c|c|c|}
\hline Species & $\begin{array}{c}\text { Frequency } \\
(\%)\end{array}$ & $\begin{array}{l}\text { Core, section, } \\
\text { interval }(\mathrm{cm})\end{array}$ \\
\hline \multicolumn{3}{|l|}{ Oligocene $>250 \mu \mathrm{m}$} \\
\hline Globigerina ampliapertura Bolli, 1957a & 1.0 & $25 \mathrm{X}-\mathrm{CC}$ \\
\hline Globigerina angiporoides Hornibrook, 1965 & 2.0 & $26 \mathrm{X}-\mathrm{CC}$ \\
\hline Globigerina binaiensis Koch, 1935 & & $\begin{array}{l}23 X-4,110-115 \\
24 X-4,110-115 \\
25 X-1,110-115\end{array}$ \\
\hline Globigerina gortanii (Borsetti, 1959) & 6.3 & $25 \mathrm{X}-\mathrm{CC}$ \\
\hline Turborotalia increbescens (Bandy, 1949) & 0.5 & $26 \mathrm{X}-\mathrm{CC}$ \\
\hline \multicolumn{3}{|l|}{$<250 \mu \mathrm{m}$} \\
\hline Aff. Clavatorella nicobarensis Srinivasan and Kennett, 1976 & $\begin{array}{l}1.3 \\
0.4\end{array}$ & $\begin{array}{l}21 X-1,110-115 \\
21 X-2,110-115\end{array}$ \\
\hline Globigerina ampliapertura Bolli, 1957a & 0.6 & $26 \mathrm{X}-3,110-115$ \\
\hline Globigerina ciperoensis Bolli, 1954 & $\begin{array}{l}1.2 \\
0.4\end{array}$ & $\begin{array}{l}21 X-3,110-115 \\
22 X-C C\end{array}$ \\
\hline Globigerina ouachitaensis Howe and Wallace, 1932 & 0.7 & $25 \mathrm{X}-3,110-115$ \\
\hline "Globorotalia" postcretacea (Myatliuk, 1950) & $\begin{array}{l}0.4 \\
0.8\end{array}$ & $\begin{array}{l}23 X-2,110-115 \\
24 X-2,110-115\end{array}$ \\
\hline Pseudohastigerina naguewichiensis (Myatliuk, 1950) $(<125 \mu \mathrm{m})$ & & $27 \mathrm{X}-1,110-115$ \\
\hline Tenuitella munda (Jenkins, 1966) & 1.1 & $22 \mathrm{X}-\mathrm{CC}$ \\
\hline Turborotalia increbescens (Bandy, 1949) & 0.5 & $26 \mathrm{X}-4,110-115$ \\
\hline \multicolumn{3}{|l|}{ upper Paleocene-Eocene $<250 \mu \mathrm{m}$} \\
\hline Chiloguembelina midwayensis (Cushman, 1940) & 2.8 & $27 \mathrm{X}-\mathrm{CC}$ \\
\hline Chiloguembelina subtriangularis Beckmann, $1957(<125 \mu \mathrm{m})$ & & $29 X-2,110-115$ \\
\hline \multirow{2}{*}{ Globigerina triangularis White, 1928} & 0.5 & $28 \mathrm{X}-2,110-115$ \\
\hline & 0.9 & $28 X-4,110-115$ \\
\hline Morozovella pseudobulloides (Plummer, 1926) & 0.5 & $28 \mathrm{X}-\mathrm{CC}$ \\
\hline Pseudohastigerina naguewichiensis (Myatliuk, 1950) & 0.5 & $27 \mathrm{X}-\mathrm{CC}, 27-29$ \\
\hline Truncorotaloides rohri Brönnimann and Bermudez, 1953 & 0.4 & $27 \mathrm{X}-\mathrm{CC}, 32-34$ \\
\hline \multicolumn{3}{|l|}{ Paleocene $>250 \mu \mathrm{m}$} \\
\hline \multirow[t]{3}{*}{ Morozovella albeari (Cushman and Bermudez, 1949) } & 1.1 & $30 X-3,110-115$ \\
\hline & 0.5 & $30 \mathrm{X}-\mathrm{CC}$ \\
\hline & 0.5 & $31 X-3,110-115$ \\
\hline Morozovella kolchidica (Morozova, 1961) (observed) & & $31 X-1,110-115$ \\
\hline \multicolumn{3}{|l|}{$<250 \mu \mathrm{m}$} \\
\hline Chiloguembelina midwayensis (Cushman, 1940) $(<125 \mu \mathrm{m})$ & & $31 X-1,110-115,31 X-2,110-115$ \\
\hline Chiloguembelina subtriangularis Beckmann, $1957(<125 \mu \mathrm{m})$ & & $30 X-3,110-115,31 X-5,110-115$ \\
\hline Morozovella albeari (Cushman and Bermudez, 1949) & 0.9 & $30 \mathrm{X}-\mathrm{CC}$ \\
\hline Planorotalites imitata (Subbotina, 1953) $(<125 \mu \mathrm{m})$ & & $31 X-4,110-115$ \\
\hline Planorotalites planoconica Subbotina, 1953) & 1.0 & $30 X-3,110-115$ \\
\hline
\end{tabular}

Rugoglobigerina pennyi

$$
\text { (PI. 1, Fig. 9) }
$$

Rugoglobigerina (Rugoglobigerina) rugosa pennyi Brönnimann, 1952a, p. 34, pl. 4 , figs. $1-3$.

Remarks. Dominant in some $>250-\mu \mathrm{m}$ fractions. Specimens possibly referable to $R$. milamensis Smith and Pessagno, 1973 and $R$. rotundata Brönnimann, 1952a have been included in the count of this species. It is connected with other Rugoglobigerina species and with Archaeoglobigerina australis Huber, 1990 by intermediate forms.

\section{Rugoglobigerina rugosa}

(Pl. 1, Figs. 10 and 11)

Globigerina rugosa Plummer, 1926, p. 38, pl. 2, figs. 10a-10d.

Remarks. This species is widespread but rarely common in the Maestrichtian. Intermediate forms with Archaeoglobigerina blowi Pessagno, 1967 and $R$. pennyi Brönnimann, 1952a occur commonly.

Genus Rugotruncana Brönnimann and Brown, 1956

\section{Rugotruncana subcircumnodifer}

(P1. 1, Figs. 12-15)

Globotruncana (Rugoglobigerina) pennyi subcircumnodifer Gandolfi, 1955, p. 73 , pl. 7 , figs. $7 \mathrm{a}-7 \mathrm{c}$
Remarks. Rare to fairly common in the middle Maestrichtian at Site 752 , it is connected with Rugoglobigerina hexacamerata Brönnimann, $1952 \mathrm{a}$ by intermediate forms.

\section{Genus Whiteinella Pessagno, 1967 \\ Whiteinella baltica}

Whiteinella baltica Douglas and Rankin, 1969, p. 197, text figs. 9a-9i.

Whiteinella brittonensis

Hedbergella brittonensis Loeblich and Tappan, 1961, p. 274-275, pl. 4, figs. $1-8$.

Family PLANOMALINIDAE Bolli, Loeblich, and Tappan, 1957 Genus Globigerinelloides Cushman and Ten Dam, 1948

This genus is common to dominant in most of the $125-250-\mu \mathrm{m}$ fractions of Cretaceous age. A number of species have been described, but we could recognize only a few of them. As their stratigraphic use is limited, we grouped them in a few loosely interpreted species. G. subcarinatus (Brönnimann, 1952a) is flat, with a final whorl with few, abruptly enlarging chambers, and this definition is not modified. $G$. multispinatus (Lalicker, 1948) includes forms with two apertures as well as the more common forms with a single aperture. It is wider than $G$. volutus (White, 1928), which has a smoother wall and chambers that 
Table 7 (continued).

\begin{tabular}{|c|c|c|}
\hline Species & $\begin{array}{c}\text { Frequency } \\
(\%)\end{array}$ & $\begin{array}{l}\text { Core, section, } \\
\text { interval }(\mathrm{cm})\end{array}$ \\
\hline \multicolumn{3}{|l|}{ Cretaceous $>250 \mu \mathrm{m}$} \\
\hline Abathomphalus mayaroensis (Bolli, 1951) & 1.1 & $33 \mathrm{X}-\mathrm{CC}$ \\
\hline Globotruncana rosetta (Carsey, 1926) & 8.9 & $31 \mathrm{X}-\mathrm{CC}$ \\
\hline Globotruncana rugosa (Marie, 1941) & 1.1 & $33 \mathrm{X}-\mathrm{CC}$ \\
\hline \multirow[t]{2}{*}{ Globotruncana ventricosa White, 1928} & 0.5 & $31 X-C C$ \\
\hline & 4.0 & $39 \mathrm{X}-\mathrm{CC}$ \\
\hline Gublerina acuta de Klasz, 1953b & 3.7 & $31 \mathrm{X}-\mathrm{CC}$ \\
\hline Planoglobulina acervulinoides (Egger, 1899) & 0.6 & $36 \mathrm{X}-\mathrm{CC}$ \\
\hline Pseudotextularia nuttalli (Voorwijk, 1937) & 0.5 & $33 X-1,115-120$ \\
\hline Rosita walfischensis (Todd, 1970) & 0.9 & $31 \mathrm{X}-\mathrm{CC}$ \\
\hline \multirow{2}{*}{ Rugoglobigerina hexacamerata Brönnimann, 1952a } & 0.5 & $31 \mathrm{X}-\mathrm{CC}$ \\
\hline & 5.7 & $33 \mathrm{X}-1,115-120$ \\
\hline \multicolumn{3}{|c|}{ Occurring outside of the count in Sample 121-758A-31X-CC only } \\
\hline \multicolumn{3}{|l|}{ Globotruncanita stuarti (de Lapparent, 1918) } \\
\hline \multicolumn{3}{|l|}{ Globotruncanita stuartiformis (Dalbiez, 1955) } \\
\hline \multicolumn{3}{|l|}{ Planoglobulina multicamerata (de Klasz, 1953a) } \\
\hline \multicolumn{3}{|l|}{ Planoglobulina riograndensis (Martin, 1972) } \\
\hline \multicolumn{3}{|l|}{ Pseudotextularia intermedia de Klasz, 1953a } \\
\hline \multicolumn{3}{|l|}{ Racemiguembelina fructicosa (Egger, 1899) } \\
\hline \multicolumn{3}{|l|}{$<250 \mu \mathrm{m}$} \\
\hline \multirow[t]{3}{*}{ Globotruncana arca (Cushman, 1926) } & 1.9 & $31 \mathrm{X}-\mathrm{CC}$ \\
\hline & 2.1 & $34 \mathrm{X}-\mathrm{CC}$ \\
\hline & 0.4 & $39 \mathrm{X}-\mathrm{CC}$ \\
\hline \multirow[t]{2}{*}{ Globotruncanella petaloidea (Gandolfi, 1955) } & 0.8 & $35 \mathrm{X}-\mathrm{CC}$ \\
\hline & 0.5 & $38 \mathrm{X}-\mathrm{CC}$ \\
\hline \multirow[t]{2}{*}{ Globotruncanella pschadae (Keller, 1946) (observed) } & 1.4 & $31 \mathrm{X}-\mathrm{CC}$ \\
\hline & & $33 \mathrm{X}-\mathrm{CC}$ \\
\hline Gublerina acuta de Klasz, 1953b & 1.4 & $31 \mathrm{X}-\mathrm{CC}$ \\
\hline \multirow[t]{3}{*}{ Hedbergella planispira (Tappan, 1940) } & 1.0 & 53R-CC \\
\hline & 0.8 & $54 \mathrm{R}-1,17-20$ \\
\hline & 2.7 & 57R-CC \\
\hline Heterohelix dentata Stenestad, 1968 & 0.6 & $33 \mathrm{X}-\mathrm{CC}$ \\
\hline Heterohelix semicostata (Cushman, 1938) & 0.5 & $37 \mathrm{X}-\mathrm{CC}$ \\
\hline Pseudotextularia nuttalli (Voorwijk, 1937) & 0.6 & $33 \mathrm{X}-\mathrm{CC}$ \\
\hline Rugoglobigerina hexacamerata Brönnimann, 1952a & 0.6 & $33 \mathrm{X}-\mathrm{CC}$ \\
\hline
\end{tabular}

increase less abruptly in size. These species, which intergrade in the lower Maestrichtian, were counted together. Finally, G. yaucoensis (Pessagno, $1960)$ is used for all forms with many (>5) chambers in the final whorl, such as G. impensus Sliter, 1977 and G. prairihillensis Pessagno, 1967.

\section{Globigerinelloides asperus}

Phanerostomum asperum Ehrenberg, 1854, p. 23, pl. 30, figs. 26a-26b, pl. 32, figs. 24,42 .

Remarks. Where present (in some samples from Site 755) G. asperus has been counted as G. yaucoensis (Pessagno, 1960).

\section{Globigerinelloides multispinatus}

Biglobigerinella multispinatus Lalicker, 1948, p. 624, pl. 92, figs. 1-3.

Remarks. This species is common to dominant in most of the 125 $250-\mu \mathrm{m}$ fractions of Cretaceous age.

\section{Globigerinelloides subcarinatus}

Globigerinella messinae subcarinata Brönnimann, 1952a, p. 44 45, pl. 1, figs. $10-11$, text figs. $21 \mathrm{a}-21 \mathrm{~m}$.

$$
\begin{aligned}
& \text { Globigerinelloides volutus } \\
& \text { (PI. 1, Figs. } 16 \text { and 17) }
\end{aligned}
$$

Globigerina voluta White, 1928, p. 197-198, pl. 28, figs. 5a-5b.

Remarks. $G$. volutus is common to dominant in most of the 125$250-\mu \mathrm{m}$ fractions of Cretaceous age.

\section{Globigerinelloides yaucoensis}

$$
\text { (Pl. 1, Figs. 18-20) }
$$

Planomalina yaucoensis Pessagno, 1960, p. 98, pl. 2, figs. 14-15, pl. 5, fig. 4.
Family GLOBIGERINIDAE Carpenter, Parker, and Jones, 1862 Genus Catapsydrax Bolli, Loeblich, and Tappan, 1957

\section{Catapsydrax dissimilis}

Globigerina dissimilis Cushman and Bermúdez, 1937, p. 25, pl. 3, figs. 4-6.

Remarks. C. dissimilis is widespread but rarely common.

\section{Catapsydrax howei}

Globigerinita howei Blow and Banner, 1962, p. 109, fig. 11, x-xiv, pl. 14, figs. $\mathrm{p}-\mathrm{r}$.

Remarks. We may have confused this species with Globigerina cryptomphala Glaessner, 1937 in poorly preserved faunas.

\section{Catapsydrax unicavus}

Catapsydrax unicavus Bolli, Loeblich, and Tappan, 1957, p. 37, pl. 7, fig. 9.

Remarks. $C$. unicavus can resemble compact Globigerinas with an aberrant final chamber. The abundances are, therefore, not reliable.

\section{Genus Globigerina d'Orbigny, 1826}

Globigerina ampliapertura

Globigerina ampliapertura Bolli, 1957a, p. 108, pl. 22, figs. 4-7.

Remarks. This distinct marker species is rare in early Oligocene faunas.

Globigerina angiporoides

(Pl. 2, Fig. 8)

Globigerina angiporoides Homibrook, 1965, p. 834-838, figs. 1-2. 
Remarks. Typical specimens are rare and many are intermediate with G. linaperta Finlay, 1939a. The species is most common at Sites 756 and 757.

\section{Globigerina angulisuturalis}

Globigerina ciperoensis angulisuturalis Bolli, 1957a, p. 109, pl. 22, fig. 11.

Remarks. This zonal marker is very rare at Sites 757 and 758. All specimens found are intermediate with G. angustiumbilicata Bolli, $1957 \mathrm{a}$.

\section{Globigerina angustiumbilicata}

(Pl. 2, Fig. 9)

Globigerina ciperoensis angustiumbilicata Bolli, 1957a, p. 109, pl. 22, figs. 12-13.

Remarks. G. angustiumbilicata is common to abundant in most middle and upper Oligocene 125-250- and $<125-\mu \mathrm{m}$ fractions. Many specimens show four abruptly enlarging chambers in the final whorl and a somewhat extraumbilical aperture. These are lower trochospiral than $G$. officinalis Subbotina, 1953 and bullaless Globigerinita glutinata (Egger, 1893).

\section{Globigerina binaiensis}

Globigerina binaiensis Koch, 1935, p. 558.

Remarks. Rare at Site 757, this species is more common at Site 758, where it ranges up into the lower Miocene, where we saw it co-occurring with Fohsella peripheroronda (Blow and Banner, 1966).

\section{Globigerina sp. "bipartita"}

(Pl. 2, Figs. 10-12)

Remarks. See Globigerina tripartita Koch, 1926.

\section{Globigerina bulloides}

Globigerina bulloides d'Orbigny, 1826, p. 277, no. 1.

Remarks. As true $G$. bulloides is very rare in the upper Oligocene at Site 758, we counted the few specimens as G. praebulloides Blow, 1959.

\section{Globigerina ciperoensis}

Globigerina ciperoensis Bolli, 1954, p. 1-3, figs. 3-4.

Remarks. This zonal marker is very rare at Sites 757 and 758. Most specimens we observed are intermediate with $G$. angustiumbilicata Bolli, 1957a.

\section{Globigerina corpulenta}

Globigerina corpulenta Subbotina, 1953, p. 76, pl. 9, figs. 5-7, pl. 10, figs. $1-4$.

Remarks. This species differs from $G$. gortanii (Borsetti, 1959) by being lower trochospiral.

\section{Globigerina cryptomphala}

Globigerina bulloides d'Orbigny, var. cryptomphala Glaessner, 1937, p. 29 , pl. 1, fig. 1.

Remarks. G. cryptomphala can resemble Catapsydrax howei (Blow and Banner, 1962). We consider it an extreme form of $G$, eocaena Guembel, 1868 with an aberrant final chamber.

\section{Globigerina daubjergensis}

Globigerina daubjergensis Brönnimann, 1953, p. 340, fig. 1.

$$
\text { Globigerina edita }
$$

Globigerina edita Subbotina, 1953, p. 62-63, pl. 2, figs. 1a-1c.

\section{Globigerina eocaena}

Globigerina eocaena Guembel, 1868, p. 662, pl. 2, fig. 109. (Em. Hagn and Lindenberg, 1966.)

Remarks. Intermediate forms with other Globigerina species are common. Aberrant final chambers occur commonly.

\section{Globigerina euapertura}

(Pl. 2, Figs. 13-16)

Globigerina euapertura Jenkins, 1960, p. 351, pl. 1, figs. 8a-8c.

Remarks. All specimens of Globigerina with three to four appressed chambers in the final whorl, when not referable to any other species, were lumped under G.euapertura. More commonly than not, the final chamber is aberrant, commonly rendering it hard to distinguish from Catapsydrax. Our use of this "species" as a "waste basket" only partly explains its extreme abundance (up to $90 \%$ ).

\section{Globigerina fringe}

Globigerina fringa Subbotina, 1950, p. 104, pl. 5, figs. 19-21.

Remarks. Forms intermediate between this species and $G$. triloculinoides Plummer, 1926 occur in the lowermost Paleocene of Site 752.

\section{Globigerina frontosa}

Globigerina frontosa Subbotina, 1953, p. 84, pl. 12, figs. 3-7.

Remarks. G. frontosa is a useful indicator for the lower half of the middle Eocene.

\section{Globigerina galavisi}

(Pl. 2, Fig. 17)

Globigerina galavisi Bermúdez, 1960, p. 1183-1184, pl. 4, fig. 3.

Remarks. G. galavisi is intermediate between $G$. venezoelana Hedberg, 1937 (which is larger and has more appressed chambers) and $G$ euapertura Jenkins, 1960 (which is smaller and more compact). Aberrant final chambers occur commonly.

\section{Globigerina gortanii}

Catapsydrax gortanii Borsetti, 1959, p. 205-212, pl. 1, fig. 1. Globigerina inaequispira

Globigerina inaequispira Subbotina, 1953, p. 69, pl. 6, figs. 1-4. Globigerina linaperta

Globigerina linaperta Finlay, 1939a, p. 125, pl. 3, figs. 54-56.

Remarks. Intermediate forms with G. eocaena Guembel, 1868 occur in the lower Eocene, and intermediate forms with G. angiporoides Hornibrook, 1965 occur in the upper Eocene/lower Oligocene.

\section{Globigerina officinalis}

Globigerina officinalis Subbotina, 1953, p. 78, pl. 11, figs. 1-7.

Remarks. G. officinalis is the ancestor of Globigerinita glutinata (Egger, 1893), from which it differs by being less compact and lacking a bulla. Four-chambered G. angustiumbilicata Bolli, 1957a specimens are lower trochospiral.

\section{Globigerina ouachitaensis}

Globigerina ouachitaensis Howe and Wallace, 1932, p. 74, pl. 10, figs. 7a-7b. Globigerina praebulloides

(Pl. 2, Figs. 18-20)

Globigerina praebulloides Blow, 1959, p. 180, pl. 8, figs. 47a-47c, pl. 9, fig. 48.

Remarks. Intermediate forms with $G$. euapertura Jenkins, 1960 occur. It grades into G. bulloides d'Orbigny, 1826 and Globoquadrina altispira globosa Bolli, 1957a in the Oligocene-Miocene at Site 758. Aberrant final chambers occur commonly.

\section{Globigerina quinqueloba} (Pl. 3, Figs. 1-3)

Globigerina quinqueloba Natland, 1938, p. 149, pl. 6, figs. 7a-7c.

Remarks. Globorotaloides suteri Bolli, 1957a is connected to a species resembling $G$. quinqueloba in the upper Oligocene at Sites 757 and 758 (Zones P22/N4) by intermediate forms. This form generally has five chambers in the final whorl (Globorotaloides suteri has three to four) 
and a more lobate outline. It is also connected with Fohsella kugleri (Bolli, 1957a), as indicated by intermediate forms.

\section{Globigerina sellii}

Globoquadrina sellii Borsetti, 1959, p. 209, pl. 1, fig. 3.

Remarks. G. sellii is usually rare and is connected with $G$. binaiensis Koch, 1935 and G. tripartita Koch, 1926 by intermediate forms.

\section{Globigerina senni}

Sphaeroidinella senni Beckmann, 1953, p. 394-395, fig. 20, pl. 26, figs. 2-4.

Remarks. Occurrences and abundances are not reliable, because as a result of poor preservation we often could not distinguish this species from Acarinina coalingensis (Cushman and Hanna, 1927), which has a more extraumbilical aperture. It seems to range somewhat higher.

\section{Globigerina spiralis}

Globigerina spiralis Bolli, 1957a, p. 70, pl. 16, figs. 16-18.

$$
\text { Globigerina tapuriensis }
$$

Globigerina tapuriensis Blow and Banner, 1962, p. 97-98, pl. 10, figs. h-k.

Remarks. We consider this form, with three chambers in the final whorl, as a variant of $G$. euapertura Jenkins, 1960 .

\section{Globigerina triangularis}

Globigerina triangularis White, 1928, p. 195-196, pl 28, figs. 1a-1b.

$$
\text { Globigerina triloculinoides }
$$

Globigerina triloculinoides Plummer, 1926, p. 134, pl. 8, fig. 10.

$$
\text { Globigerina tripartita }
$$

Globigerina bulloides d'Orbigny, var. tripartita Koch, 1926, p. 746, figs. 21a-21b.

Remarks. This species is always underrepresented because it is commonly broken or damaged. Aberrant final chambers occur commonly. A variety of this species with two very large chambers in the final whorl (informally named Globigerina sp. “bipartita”; Pl. 2, Figs. 10-12) occurs in the Oligocene at Site 758.

\section{Globigerina velascoensis}

Globigerina velascoensis Cushman 1925d, p. 19, pl. 3, fig. 6 .

$$
\text { Globigerina venezoelana }
$$

Globigerina venezoelana Hedberg, 1937, p. 681, pl. 92, fig. 7.

Remarks. If present, we counted this species as G. galavisi Bermúdez, 1960.

\section{Genus Globigerinatheka Brönnimann, 1952b \\ Globigerinatheka barri}

Globigerinatheka barri Brönnimann, 1952b, p. 27-28, fig. 1 .

Remarks. As this species is rare and always co-occurs with $G$. subconglobata (Shutskaya, 1958), of which it may be a variety, we counted it as that species.

\section{Globigerinatheka index}

(Pl. 3, Figs. 4-9)

Globigerinoides index Finlay, 1939a, p. 125, pl. 14, figs. 85-88.

Remarks. Small specimens, usually with globular chambers and lacking accessory apertures, occur much more commonly than the species. Their distribution is listed under Globigerinatheka sp. cf. G. index.

Globigerinatheka subconglobata

Globigerinoides subconglobatus Chalilov, var. subconglobatus Shutskaya, 1958 , p. 86-87, pl. 1, figs. 4-11.

\section{Genus Globigerinita Brönnimann, 1951 \\ Globigerinita glutinata}

Globigerina glutinata Egger, 1893, p. 371, pl. 13, figs. 19-21.
Remarks. This species is interpreted to include both forms with and without bulla. Many different forms occur in the Oligocene-Miocene. Globigerinita naparimaensis Brönnimann, 1951 and Tinophodella ambitacrena Loeblich and Tappan, 1957 are considered synonyms of Globigerinita glutinata.

\section{Globigerinita uvula}

Pylodexia uvula Ehrenberg, 1861, p. 206-207, 308.

Remarks. G. uvula is very rare. It was found in some late Oligocene age samples.

\section{Genus Globigerinoides Cushman, 1927a}

Globigerinoides, indicative for the Neogene, was observed in Samples 121. $756 \mathrm{~B}-7 \mathrm{H}-\mathrm{CC}$ and $121-757 \mathrm{~B}-11 \mathrm{H}-2,110-115 \mathrm{~cm}$. We recognized the following species:

\section{Globigerinoides altiaperturus}

$$
\text { (Pl. 3, Fig. 10) }
$$

Globigerinoides triloba altiapertura Bolli, 1957a, p, 113, pl. 25, figs. 7a-7c.

$$
\text { Globigerinoides sacculifer }
$$

Globigerina sacculifera Brady, 1877, p. 535. Figs. in Brady, 1884, p. 604, pl. 80 , figs. 11-17, pl. 81 , fig. 2, pl. 82, fig. 4.

\section{Globigerinoides trilobus}

(Pl. 3, Fig. 11)

Globigerina triloba Reuss, 1850, p. 374, pl. 447, figs. 11a-11c.

Genus Globoquadrina Finlay, 1947

Globoquadrina altispira globosa

Globoquadrina altispira globosa Bolli, 1957a, p. 111, pl. 24, figs. 9-10.

Remarks. Occurring in the Oligocene-Miocene at Site 758, it is connected to Globigerina praebulloides Blow, 1959 by intermediate forms.

\section{Globoquadrina dehiscens}

Globorotalia dehiscens Chapman, Parr, and Collins, 1934, p. 569, pl. 11, figs. 36a-36c.

Remarks. G. dehiscens is common to abundant in the Oligocene-Miocene at Sites 752, 754, and 756. Aberrant final chambers are very common.

\section{Globoquadrina praedehiscens}

$$
\text { (Pl. 3, Figs. } 12 \text { and 13) }
$$

Globoquadrina dehiscens praedehiscens Blow and Banner, 1962, p. 116, pl. 15 , figs. q-s.

Remarks. G. praedehiscens is connected to Globigerina euapertura Jenkins, 1960), its probable ancestor, by intermediate forms. Aberrant final chambers occur commonly.

Genus Zeaglobigerina Kennett and Srinivasan, 1983

Zeaglobigerina labiacrassata

Globigerina labiacrassata Jenkins, 1966, p. 1102, fig. 8, nos. 64-71.

$$
\text { Zeaglobigerina woodi }
$$

Globigerina woodi Jenkins, 1960, p. 352, pl. 2, figs. 2a-2c.

\section{Family GLOBOROTALIIDAE Cushman, 1927a} Genus Acarinina Subbotina, 1953

Acarinina angulosa

Globigerina soldadoensis angulosa Bolli, 1957b, p. 71, pl. 16, figs. 4-6.

Remarks. See A. coalingensis (Cushman and Hanna, 1927).

\section{Acarinina broedermanni}

Globorotalia broedermanni Cushman and Bermúdez, 1949, p. 40, pl. 7, figs. 22-24. 
Acarinina coalingensis

(Pl. 3, Figs. 14-20, and Pl. 4, Fig. 6)

Globigerina coalingensis Cushman and Hanna, 1927, p. 219, pl. 14, figs. $4 a-4 b$.

Remarks. This species is the central form in a plexus of four-chambered forms with more or less appressed chambers and a rounded or somewhat angular periphery (A. soldadoensis angulosa (Bolli, 1957b), A. esnaensis LeRoy, 1953, A. nitida (Martin, 1943), A. pseudotopilensis (Subbotina, 1953), and A. soldadoensis (Brönnimann, 1952c)). Because these are connected by intermediate forms and most have similar ranges, we counted them together. A. primitiva (Finlay, 1947) (= Globoquadrina primitiva) is a junior synonym.

\section{Acarinina densa}

(Pl. 4, Figs. 1 and 2 and cf Fig. 5 )

Pulvinulina crassata Cushman, var. densa Cushman, 1925b, p. 301.

Remarks. This species (of which A. bullbrooki (Bolli, 1957a) is a junior synonym) is sporadically dominant in middle Eocene faunas. It is one of the few middle Eocene Acarininas clearly distinguishable from the A. coalingensis plexus.

\section{Acarinina esnaensis}

Globigerina esnaensis LeRoy, 1953, p. 31, pl. 6, figs. 8-10.

Remarks. See A. coalingensis (Cushman and Hanna, 1927).

Acarinina gravelli

(Pl. 4, Fig. 4)

Globigerina gravelli Brönnimann, 1952a, p. 12-13, pl. 1, figs. 16-18.

Remarks. Forms intermediate between A. gravelli and A. pentacamerata (Subbotina, 1947) occur. Also, there is some intergradation with the $A$. coalingensis plexus.

\section{Acarinina mckannai}

Globigerina mckannai White, 1928, p. 194, pl. 27, fig. 16.

$$
\text { Acarinina nitida }
$$

Globigerina nitida Martin, 1943, p. 115, pl. 7, figs. 1a-1c.

Remarks. See A. coalingensis (Cushman and Hanna, 1927).

\section{Acarinina pentacamerata}

(Pl. 4, Fig. 3, and of Fig. 5)

Globorotalia pentacamerata Subbotina, 1947, p. 128, pl. 7, figs. 12-17 (non pl. 9, figs. 24-26).

Remarks. Intermediate forms between this species and $A$. broedermanni and A. gravelli occur, with some intergrading with the $A$. coalingensis plexus.

\section{Acarinina primitiva}

Globoquadrina primitiva Finlay, 1947, p. 291, pl. 8, figs. 129-134.

Remarks. See A. coalingensis (Cushman and Hanna, 1927).

Acarinina pseudotopilensis

Acarinina pseudotopilensis Subbotina, 1953, p. 227, pl. 21, figs. 8-9, pl. 22, figs. 1-3.

Remarks. See A. coalingensis (Cushman and Hanna, 1927).

\section{Acarinina soldadoensis}

Globigerina soldadoensis Brönnimann, 1952c, p. 7, 9, pl. 1, figs. 1-9.

Remarks. See A. coalingensis (Cushman and Hanna, 1927).

\section{Acarinina wilcoxensis}

$$
\text { (PI. 4, Fig. 7) }
$$

Globorotalia wilcoxensis Cushman and Ponton, 1932a, p. 71, pl. 9, figs. $10 \mathrm{a}-10 \mathrm{c}$.
Remarks. Specimens clearly referable to this species are common (27\%) only in Sample 121-752A-13X-3, 110-115 cm.

\section{Genus Clavatorella Blow, 1965 \\ Clavatorella nicobarensis (PI. 4, Figs. 8-12)}

Clavatorella nicobarensis Srinivasan and Kennett, 1976, p. 74-79, pl. 1, figs. $1-13$.

Remarks. A species indistinguishable from C. nicobarensis occurs in the uppermost Oligocene at Sites 757 and 758 , although its reported range is upper Miocene-Pliocene.

Genus Fohsella Kennett and Srinivasan, 1983

Fohsella kugleri

(Pl. 4, Figs. 13 and 14)

Globorotalia kugleri Bolli, 1957a, p. 118, pl. 28, figs. 5-6.

Remarks. F. kugleri is common to dominant in the $125-250-\mu \mathrm{m}$ and $<125-\mu \mathrm{m}$ fractions of many upper Oligocene samples. The species is connected to a form related to Globorotaloides suteri Bolli, 1957a, (here named Globigerina sp. cf. G. quinqueloba Natland, 1938) by intermediate forms. As the phylogenetical position of $F$. kugleri is uncertain, this may be significant.

\section{Genus Globigerinella Cushman, 1927a}

Globigerinella obesa

Globorotalia obesa Bolli, 1957a, p. 119, pl. 29, figs. 2-3.

Remarks. $G$. obesa is rare in many late Oligocene faunas.

$$
\begin{aligned}
& \text { Genus Globorotalia Cushman, 1927a } \\
& \text { "Globorotalia" postcretacea }
\end{aligned}
$$$$
\text { (Pl. 4, Figs. 15-17) }
$$

Globigerina postcretacea Myatliuk, 1950, p. 280, pl. 4, fig. 3.

Remarks. Small specimens occur in the $<125-\mu \mathrm{m}$ fraction of many Oligocene samples. Superficially, it can resemble Globigerina angustiumbilicata, but has a smoother wall and a more clearly extraumbilical aperture.

\section{Genus Globorotaloides Bolli, 1957a \\ Globorotaloides suteri \\ (Pl. 4, Figs. 18-20)}

Globorotaloides suteri Bolli, 1957a, p. 117, pl. 27, figs. 9-13.

Remarks. Usually dominant (commonly about $60 \%$ ) in the $125-250$ $\mu \mathrm{m}$ fractions, $G$. suteri is also common in the $<125-\mu \mathrm{m}$ fractions. In the upper Oligocene samples the species is connected a four- to five-chambered form with a more lobulate outline by intermediate forms. (See Globigerina quinqueloba Natland, 1938.)

Genus Jenkinsella Kennett and Srinivasan, 1983

Jenkinsella continuosa

Globorotalia opima Bolli, subsp. continuosa Blow, 1959, p. 218, pl. 19, figs. $125 \mathrm{a}-125 \mathrm{c}$

Remarks. Intermediate forms with other Jenkinsella species occur commonly.

\section{Jenkinsella mayeri}

Globorotalia mayeri Cushman and Ellisor, 1939, p. 11, pl. 2, figs. 4a-4c.

Remarks. Most specimens are intermediate between $J$. continuosa (Blow, 1959) and J. mayeri. We consider J. siakensis (LeRoy, 1939) a junior synonym, in agreement with Bolli and Saunders, 1982.

\section{Jenkinsella nana}

Globorotalia opima nana Bolli, 1957a, p. 118, pl. 28, fig. 3. 
Remarks. Intermediate forms with other Jenkinsella species occur commonly.

\section{Jenkinsella opima}

Globorotalia opima opima Bolli, 1957a, p. 117, pl. 28, figs. 1-2.

Remarks. Intermediate forms with other Jenkinsella species are common. In order to preserve its value as a marker species we counted all intermediate forms as $J$. continuosa (Blow, 1959) or $J$. nana (Bolli, 1957a).

\section{Genus Morozovella McGowran, 1968}

Intermediate forms are very common, especially between the ornamented forms, and usually involve the number of chambers in the final whorl and the height of the umbilical side.

\section{Morozovella acuta}

Globorotalia wilcoxensis Cushman and Ponton, var. acuta Toulmin, 1941, p. 608 , pl. 82 , figs. $6-8$.

\section{Morozovella aequa}

Globorotalia crassata (Cushman), var. aequa Cushman and Renz, 1942, p. 12 pl. 3 , fig. 3 .

\section{Morozovella albeari}

Globorotalia albeari Cushman and Bermúdez, 1949, p. 33, pl. 6, figs. 13-15. Morozovella angulata

Globigerina angulata White, 1928, p. 191, pl. 27, fig. 13. Morozovella aragonensis

Globorotalia aragonensis Nuttall, 1930, p. 288, pl. 24, figs. 6-11.

Remarks. This robust, easily identifiable species is a useful indicator of the lower half of the middle Eocene, even though it is usually rare.

\section{Morozovella caucasica}

Globorotalia aragonensis Nuttall, var. caucasica Glaessner, 1937, p. 31, pl. 1, fig. 6 .

Remarks. The encountered specimens show only a weak ornamentation and are thus intermediate with $M$. aragonensis (Nuttall, 1930). This species is a good indicator of the upper part of the lower Eocene and the lowermost middle Eocene.

\section{Morozovella conicotruncata}

Globorotalia conicotruncata Subbotina, 1947, p. 115-116, pl. 4, figs. 11-13, pl. 9, figs. 9-10.

Remarks. It is connected to $M$. velascoensis (Cushman, 1925d) by intermediate forms with weak ornamentation.

\section{Morozovella convexa}

Globorotalia convexa Subbotina, 1953, p. 209, pl. 17, figs. 2-3.

Morozovella crassata

Pulvinulina crassata Cushman, 1925b, p. 300, pl. 7, fig. 4 .

Remarks. We consider the well-known $M$. spinulosa (Cushman, $1927 \mathrm{~b})$ a junior synonym of this species.

\section{Morozovella inconstans}

Globigerina inconstans Subbotina, 1953, p. 58, pl. 3, figs. 1-2.

$$
\text { Morozovella kolchidica }
$$

Globorotalia kolchidica Morozova, 1961, p. 17, pl. 2, fig. 2.

Morozovella marginodentata

Globorotalia marginodentata Subbotina, 1953, p. 212-213, pl. 17, figs. 14-16, pl. 18, figs. 1-3.

\section{Morozovella occlusa}

Globorotalia occlusa Loeblich and Tappan, 1957, p. 191, pl. 55, fig. 3.

$$
\text { Morozovella praecursoria }
$$

Acarinina praecursoria Morozova, 1957, p. 1111, fig. 1.

\section{Morozovella pseudobulloides}

Globigerina pseudobulloides Plummer, 1926, p. 33, pl. 8, fig. 9.

Remarks. The recorded occurrence of this species in the 125-250- $\mu \mathrm{m}$ fraction of samples from Zones P3b and P4 at Site 758 probably concerns small, immature specimens of $M$. variospira (Belford, 1984).

$$
\text { Morozovella pusilla }
$$

Globorotalia pusilla pusilla Bolli, 1957b, p. 78, pl. 20, figs. 8-10.

Morozovella simulatilis

Discorbina simulatilis Schwager, 1883, p. 120, pl. 29, fig. 15.

\section{Morozovella subbotinae}

Globorotalia subbotinae Morozova, 1939, p. 80-81, pl. 2, fig. 16.

$$
\text { Morozovella trinidadensis }
$$

Globorotalia trinidadensis Bolli, 1957a, p. 73, pl. 16, figs. 19-23.

$$
\text { Morozovella uncinata }
$$

Globorotalia uncinata Bolli, 1957a, p. 74, pl. 17, figs. 13-15.

Morozovella variospira (Belford, 1984), em. van Eijden and Smit

(Fig. 26; Pl. 5, Figs. 1-8)

Globorotalia (Turborotalia) variospira Belford, 1984, p. 18, pl. 24, figs. 15-17, pl. 25, figs. 1-7.

Description. Umbilical side: Aperture extraumbilical-umbilical, a medium to high arc, on the last to the last three chambers bordered by an umbilical tooth or wide lip. Umbilicus wide and deep, usually partially covered by an umbilical tooth or teeth (Fig. 26 and Pl. 5, Figs. 1 and 3). Sutures straight and deeply depressed. Four to five chambers in the final whorl (usually four and a half). Chambers increasing abruptly in size as added, but the final two or three chambers can be of subequal size (cf

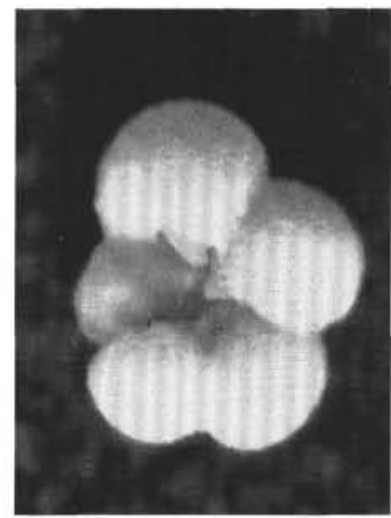

A

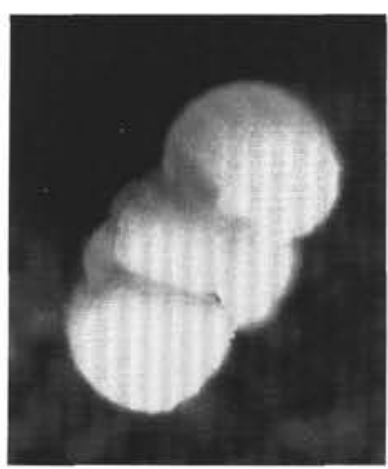

C

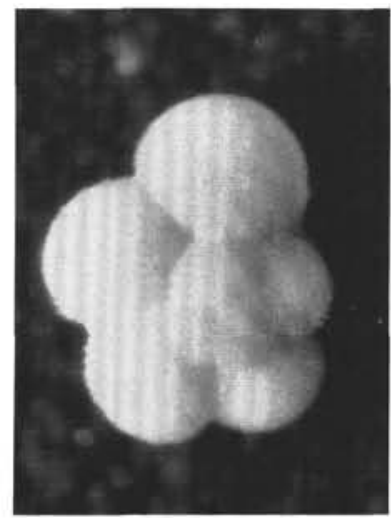

B

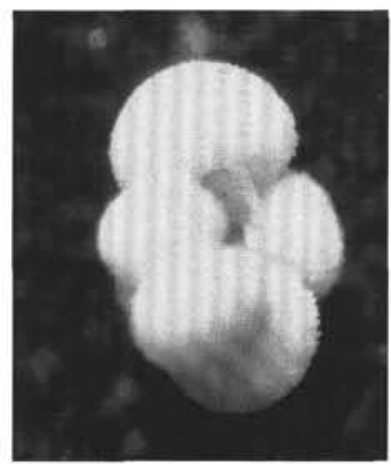

D
Figure 26. Morozovella variospira (Belford, 1984), em., Sample 121-758A30X-CC. A. Umbilical view. B. Spiral view. C. Side view. D. Oblique side view. Magnification 50x. 
Pl. 5, Figs. 1 with 2). Some of the final chamber(s) can be displaced toward the umbilicus.

Spiral side: Outline strongly lobate. Sutures straight, with some slightly curved backward, and deeply depressed. Chambers strongly inflated. Twelve to 15 chambers, arranged in three to three and a half whorls (Fig. 26 and Pl. 5, Figs. 6 and 7).

Lateral view: Trochospire is usually low, sometimes moderately high in specimens with chambers displaced toward the umbilicus. Profile broadly rounded (Fig. 26 and Pl. 5, Figs. 4 and 5).

Wall calcareous, densely perforate surface with small pustules that grade into a honeycomb pattern. Diameter of full-grown specimens up to $0.80 \mathrm{~mm}$, and usually between 0.4 and $0.7 \mathrm{~mm}$.

Intraspecies variability. Smaller, immature specimens with only four chambers in the final whorl may have a broad lip over the aperture of the final chamber only. The umbilicus of these specimens is narrower. Large, mature specimens may have five chambers in the final whorl, which increase gradually in size, with a number of chambers of subequal size. These specimens usually show prominent apertural teeth and a wide umbilicus. In spiral view, the stage with four rapidly enlarging chambers per whorl is easily discerned. The apertural tooth of displaced chambers is commonly weakly developed.

Diagnosis. $M$. variospira differs from all other Paleocene species of planktonic foraminifers by the presence of apertural teeth. This, together with its large size, makes it very conspicuous and easily recognized. Small, immature specimens resemble $M$. pseudobulloides (Plummer, 1926), which they differ from by their larger size, wider umbilicus, and the presence of an apertural lip or tooth on at least one chamber. The only species morphologically similar are Globoquadrina altispira globosa Bolli, 1957a and Neogloboquadrina dutertrei (d'Orbigny, 1839), which have radically different stratigraphical ranges and are phylogenetically unrelated.

Phylogeny. Intermediate forms between this species and $M$. pseudobulloides in the lower part of the range of $M$. variospira show that it descended from $M$. pseudobulloides. It may represent a gerontic form of that species.

Stratigraphic distribution. Lower part of Zone P3a ( $M$. angulata Zone) to halfway Zone P4 ( $P$. pseudomenardii Zone). At Site 758 it occurs in Samples 121-758A-30X-1, 115-120 cm, to 121-758A-31X-3, 115-120 $\mathrm{cm}$.

The species is not as variable in coiling mode as Belford (1984) thought it was, and almost all specimens are very low trochospiral. The most important difference with the original description is that prominent apertural teeth are present, which were not observed by Belford. Its phylogenetic position and stratigraphic range are now known in some detail.

Remarks. The figured specimens will be deposited in the Dutch National Museum of Natural History in Leiden, under the first author's name.

Morozovella velascoensis

Pulvinulina velascoensis Cushman, 1925d, p. 19, pl. 3, fig. 5.

Genus Planorotalites Morozova, 1957

Planorotalites australiformis

(Pl. 5, Figs. 9 and 10)

Globorotalia australiformis Jenkins, 1966, p. 1112-1113, fig. 11, nos. 92-96.

Remarks. This species (probably a variant of $P$. planoconica (Subbotina, 1953)) is conspicuously present in the $125-250-\mu \mathrm{m}$ fraction of Sample 121-752A-13X-3, 110-115 cm, of early middle Eocene age.

\section{Planorotalites chapmani}

Globorotalia chapmani Parr, 1938, p. 87, pl. 9, figs. 8-9.

Planorotalites compressa

Globigerina compressa Plummer, 1926, p. 135, pl. 8, fig. 11. Planorotalites ehrenbergi

Globorotalia ehrenbergi Bolli, 1957b, p. 77, pl. 20, figs. 18-20. Planorotalites imitata

Globorotalia imitata Subbotina, 1953, p. 206, pl. 16, figs. 14-16.

\section{Planorotalites planoconica}

Globorotalia planoconica Subbotina 1953, p. 210, pl. 17, figs. 4-6.

Planorotalites pseudomenardii

Globorotalia pseudomenardii Bolli, 1957b, p. 77, pl. 20, figs. 14-17.

Genus Protentella Lipps, 1964

Protentella clavicamerata

Protentella clavicamerata Jenkins, 1977, p. 308-312, pl. 4, figs. 12-14, pl. 5, figs. $1-8$.

Protentella prolixa

(PI. 5, Figs. 11 and 12)

Protentella prolixa Lipps, 1964, p. 124, pl. 2, figs. 8-9.

Remarks. Although $P$. prolixa is reportedly restricted to the upper Miocene and the Pliocene, we found specimens indistinguishable from this species in the upper Oligocene of Sites 757 and 758.

Genus Tenuitella Fleisher, 1974

Tenuitella munda

Globorotalia munda Jenkins, 1966, p. 1121, fig. 14, nos. 126-133, fig. 15, nos. 152-156.

Remarks. Usually rare if present and commonly hard to recognize, this species does not seem to be a good marker species, although it is used as such by Jenkins (1966).

Genus Truncorotaloides Brönnimann and Bermúdez, 1953

Truncorotaloides collactea

Globorotalia collactea Finlay, 1939b, p. 327, pl. 29, figs. 164-165.

Truncorotaloides rohri

Truncorotaloides rohri Brönnimann and Bermúdez, 1953, p. 818-819, pl. 87, figs. 7-9.

\section{Truncorotaloides topilensis}

Globigerina topilensis Cushman, 1925c, p. 7, pl. 1, fig. 9.

Remarks. $T$, topilensis is rare and not quite typically developed in Sample 121-757B-17H-CC.

\section{Genus Turborotalia Cushman and Bermúdez, 1949}

All Turborotalia species are rare. This is due to the fact that they are susceptible to dissolution, combined with the fact that most of them are restricted to low latitudes.

Turborotalia cerroazulensis

Globigerina cerro-azulensis Cole, 1928, p. 17, pl. 1, figs. 11-13.

Turborotalia cocoaensis

Globorotalia cocoaensis Cushman, 1928, p. 75, pl. 10, fig. 3.

Turborotalia cunialensis

Globorotalia cerroazulensis cunialensis Toumarkine and Bolli, 1970, p. 144, pl. 1, fig. 37.

Turborotalia increbescens

Globigerina increbescens Bandy, 1949, p. 120, pl. 23, fig. 3.

Turborotalia pomeroli

Globorotalia cerroazulensis pomeroli Toumarkine and Bolli, 1970, p. 140, pl. 1 , figs. 10-18, pl. 2, figs. 1-2, 11-19.

Family HANTKENINIDAE Cushman, 1927a Genus Cassigerinella Pokorný, 1955

Cassigerinella chipolensis

Cassidulina chipolensis Cushman and Ponton, 1932b, p. 98, pl. 15, fig. 2.

Remarks. C. chipolensis is rare but consistently present in the Oligocene of Site 758, and very rare at Site 757. 


\section{Genus Cribrohantkenina Thalmann, 1942}

\section{Cribrohantkenina inflata}

Hantkenina inflata Howe, 1928, p. 14, pl. 14, fig. 2.

Remarks. C. inflata was observed in samples from Section 121757B-14H by a shipboard scientist.

\section{Genus Hantkenina Cushman, 1925a}

Fragments (usually spines) of unidentifiable species of Hantkenina occur in Samples 121-756C-6X-CC, 121-756C-7X-4, 110-115 cm, 121$756 \mathrm{C}-7 \mathrm{X}-\mathrm{CC}$, and $121-757 \mathrm{~B}-14 \mathrm{H}-1,110-115 \mathrm{~cm}$.

\section{Hantkenina alabamensis}

Hantkenina alabamensis Cushman, 1925a, p. 3, fig. 1, pl. 1, figs. 1-6.

Remarks. We found a single specimen in Sample 121-757B-14H-1, $110-115 \mathrm{~cm}$

\section{Hantkenina brevispina}

Hantkenina brevispina Cushman 1925a, p. 1, pl. 2, fig. 3 .

Remarks. We found a single specimen in Sample 121-756C-6X-CC.

Genus Pseudohastigerina Banner and Blow, 1959

Pseudohastigerina micra

Nonion micrus Cole, 1927, p. 22, pl. 5, fig. 12.

Remarks. $P$. micra is usually rare in the middle and upper Eocene, and very rare in the lower Oligocene.

\section{Pseudohastigerina naguewichiensis}

Globigerinella naguewichiensis Myatliuk, 1950, p. 281, pl. 4, figs. 4a-4b.

Remarks. This species occurs only rarely outside of the $<125-\mu \mathrm{m}$ fraction, usually in the lower Oligocene.

\section{Pseudohastigerina wilcoxensis}

Nonion wilcoxensis Cushman and Ponton, 1932a, p. 64, pl. 8, fig. 11.

Remarks. $P$. wilcoxensis was found only in Sample 121-752A-13X-2, $110-115 \mathrm{~cm}$

\section{ACKNOWLEDGMENTS}

We thank J. E. van Hinte for critically reading the manuscript, P. H. Willekes, R. van Elsas, M. J. Boone, and M. Konert for processing samples, analyzing carbonate content, and making available the computer programs for plotting species distribution and frequencies. A. J. Nederbragt and J. A. Manuputty are thanked for assisting with species determinations. S. M. Kars is thanked for assisting with operating the SEM and preparation of figures.

\section{REFERENCES}

Bandy, O. L., 1949. Eocene and Oligocene foraminifera from Little Stave Creek, Clarke County, Alabama. Bull. Am. Paleontol., 32:35-240.

Banner, F. T., and Blow, W. H., 1959. The classification and stratigraphical distribution of the Globigerinaceae. Palaeontology, 2:1-27.

Banner, F. T., and Blow, W. H., 1965. Progress in the planktonic foraminiferal biostratigraphy of the Neogene. Nature, 208:1164-1166.

Beckmann, J. P., 1953. Die Foraminiferen der Oceanic Formation, (Eocän-Oligocän) von Barbados, Kl. Antillen. Eclogae Geol. Helv., 46:301-412.

1957. Chiloguembelina Loeblich and Tappan and related foraminifera from the lower Tertiary of Trinidad, B.W.I. Bull. U.S. Natl. Mus., 215:83-95.

Belford, D. J., 1984. Tertiary foraminifera and age of sediments, OK Tedi-Wabag, Papua New Guinea. Bull. Bur. Min. Resour., Geol. Geophys. (Aust.), 216.

Berger, W. H., 1971. Sedimentation of planktonic foraminifera. Mar. Geol., 11:325-358.

Berggren, W. A., 1977. Atlas of Palaeogene planktonic foraminifera. Some species of the genera Subbotina, Planorotalites, Morozovella,
Acarinina and Truncorotaloides. In Ramsay, A.T.S. (Ed.), Oceanic Micropaleontology: London (Academic Press), 1:205-300.

Berggren, W. A., Kent, D. V., Flynn, J. J., and Van Couvering, J. A., 1985. Cenozoic geochronology. Geol. Soc. Am. Bull., 96:1407-1418.

Berggren, W. A., Lohmann, G. P., and Poore, R. Z., 1974. Shore laboratory report on Cenozoic planktonic foraminifera: Leg 22. In von der Borch, C. C., Sclater, J. G., et al., Init. Repts. DSDP, 22: Washington (U.S. Govt. Printing Office), 635-655.

Bermúdez, P. J., 1949. Tertiary smaller foraminifera of the Dominican Republic. Cushman Lab. Foramin. Res. Spec. Publ., 25.

1960. Contribución al estudio de las Globigerinidae de la región Caribe-Antillana (Paleoceno-Reciente). Mem. Tercer Congr. Geol. Venezolano, 3:1119-1393.

Blow, W. H., 1959. Age, correlation and biostratigraphy of the upper Tocuyo (San Lorenzo) and Pozón Formations, eastern Falcon, Venezuela. Bull. Am. Paleontol., 39:67-251.

1965. Clavatorella, a new genus of the Globorotaliidae. Micropaleontology, 11:365-368.

1969. Late middle Eocene to Recent planktonic foraminifera biostratigraphy. In Brönnimann, P., and Renz, H. H. (Eds.), Proc. First Int. Conf. Planktonic Microfossils, Geneva: Leiden (E. J. Brill), $1: 199-422$.

1979. The Cainozoic Globigerinida: Leiden (E. J. Brill).

Blow, W. H., and Banner, F. T., 1962. The mid-Tertiary (upper Eocene to Aquitanian) Globigerinacea. In Eames, F. E., Banner, F. T., Blow, W. H., and Clarke, W. J. (Eds.), Fundamentals of Mid-Tertiary Stratigraphical Correlation: Cambridge (Cambridge Univ. Press), 61151

1966. The morphology, taxonomy and biostratigraphy of Globorotalia barisanensis LeRoy, Globorotalia fohsi Cushman and Ellisor and related taxa. Micropaleontology, 14:357-360.

Bolli, H. M., 1945. Zur Stratigraphie der Oberen Kreide in den höheren helvetischen Decken. Eclogae Geol. Helv., 37:217-329.

1951. The genus Globotruncana in Trinidad, B.W.I. J. Paleontol., 25:187-199.

1954. Note on Globigerina concinna, Reuss 1850. Cushman Found. Foraminiferal Res. Contrib., 5:1-3.

1957a. Planktonic foraminifera from the Oligocene-Miocene Cipero and Lengua Formations of Trinidad, B.W.I. In Loeblich, A. R., Jr., Tappan, H., Beckmann, J. P., Bolli, H. M., Gallitelli, E. M., and Troelsen, J. C. (Eds.), Studies in Foraminifera. Bull. U.S. Nat. Mus., 215:97-124.

1957b. The genera Globigerina and Globorotalia in the Paleocene-lower Eocene Lizard Springs Formation of Trinidad, B.W.I. Bull. U.S. Nat. Mus., 215:61-82.

Bolli, H. M., Loeblich, A. R., Jr., and Tappan, H., 1957. Planktonic foraminiferal families Hantkeninidae, Orbulinidae, Globorotaliidae, and Globotruncanidae, Bull. U.S. Nat. Mus., 215:3-50.

Bolli, H. M., and Saunders, J. B., 1982. Globorotalia mayeri and its relationship to Globorotalia siakensis and Globorotalia continuosa. J. Foraminiferal Res., 12:39-50.

1985. Oligocene to Holocene low latitude planktonic foraminifera. In Bolli, H. M., Saunders, J. B., and Perch-Nielsen, K. (Eds.), Plankton Stratigraphy: Cambridge (Cambridge Univ. Press), 155262.

Boltovskoy, E., 1974. Neogene planktonic foraminifera of the Indian Ocean (DSDP, Leg 26). In Davies, T. A., Luyendyk, B. P., et al., Init. Repts. DSDP, 26: Washington (U.S. Govt. Printing Office), 675-741.

Borsetti, A. M., 1959. Tre nuovi Foraminiferi planctonici dell'Oligocene piacentino. G. Geol., 27:205-212.

Brady, H. B., 1877. Supplementary note on the foraminifera of the Chalk (?) of the New Britain Group. Geol. Mag., London, 1877, n. ser., decade 2, 4(12):534-546.

1884. Report on the Foraminifera dredged by H.M.S. Challenger during the years 1873-1876. Rep. Sci. Results H.M.S. Challenger Exped., Zool., 9:1-814.

Brönnimann, P., 1951. Globigerinita naparimaensis, n. gen., n. sp., from the Miocene of Trinidad, B.W.I. Cushman Found. Foraminiferal Res. Contrib., 2:16-18.

1952a. Globigerinidae from the Upper Cretaceous (Cenomanian-Maestrichtian) of Trinidad, B.W.I. Bull. Am. Paleontol., 34:571 . 
1952b. Globigerinoita and Globigerinatheka, new genera from the Tertiary of Trinidad, B.W.I. Cushman Found. Foraminiferal Res. Contrib., 3:25-28.

1952c. Trinidad Paleocene and lower Eocene Globigerinidae. Bull. Am. Paleontol, 34:1-34.

1953. Note on planktonic foraminifera from Danian deposits of Jutland, Denmark. Eclogae Geol. Helv., 45:339-341.

Brönnimann, P., and Bermúdez, P. J., 1953. Truncorotaloides, a new foraminiferal genus from the Eocene of Trinidad, B.W.I.J.Paleontol., 27:817-820.

Brönnimann, P., and Brown, N., 1953. Observations on some planktonic Heterohelicidae from the Upper Cretaceous of Cuba. Cushman Found. Foraminiferal Res. Contrib., 4:150-156.

1956. Taxonomy of the Globotruncanidae. Eclogae Geol.Helv. 48:503-561.

1958. Hedbergella, a new name for a Cretaceous planktonic foraminiferal genus. Wash. Acad. Sci. J., 48:15-17.

Brotzen, F., 1934. Foraminiferen aus dem Senon Palästinas. Z. Dtsch. Vereins Erforschung Palästinas, 57:28-72.

1942. Die Foraminiferengattung Gavellina, n. gen. und die Systematik der Rotaliiformes. Sver. Geol. Unders., Ser. C., No. 451, Ars. 36, 8:1-60.

Caron, M., 1985. Cretaceous planktonic foraminifera. In Bolli, H. M., Saunders, J. B., and Perch-Nielsen, K. (Eds.), Plankton Stratigraphy: Cambridge (Cambridge Univ. Press), 17-86.

Carpenter, W. B., Parker, W. K., and Jones, T. R., 1862. Introduction to the Study of the Foraminifera. London (Ray Soc. Publ.).

Carsey, D. O., 1926. Foraminifera of the Cretaceous of Central Texas. Texas Univ. Bull., 2612:1-56.

Chapman, F., Parr, W. J., and Collins, A. C., 1934. Tertiary Foraminifera of Victoria, Australia-the Balcombian deposits of Port Phillip, pt. 3. Linn. Soc. London J., Zool., 38:553-577.

Cole, W. S., 1927. A foraminiferal fauna from the Guayabal Formation in Mexico. Bull. Am. Paleontol., 14(51).

1928. A foraminiferal fauna from the Chapapote Formation in Mexico. Bull. Am. Paleontol., 14(53):1-32.

Cushman, J. A., 1925a. A new genus of Eocene foraminifera. U.S. Nat. Mus. Proc., 66:1-4.

1925b. An Eocene fauna from the Moctezuma River, Mexico. Bull. Am. Assoc. Petrol. Geol., 9:298-303.

1925c. New foraminifera from the upper Eocene of Mexico. Cushman Lab. Foraminiferal Res. Contrib., 1:4-8. 1925 d. Some new foraminifera from the Velasco Shale of Mexico. Cushman Lab. Foraminiferal Res. Contrib., 1:18-23. 1926. Some foraminifera from the Mendez Shale of Eastern Mexico. Cushman Lab. Foraminiferal Res. Contrib., 2:16-28. $1927 \mathrm{c}$. An outline of a reclassification of the foraminifera Cushman Lab. Foraminiferal Res. Contrib., 3:1-105. $1927 \mathrm{~b}$. New and interesting foraminifera from Mexico and

Texas. Cushman Lab. Foraminiferal Res. Contrib., 3:111-119. 1927c. Some new genera of the foraminifera. Cushman Lab. Foraminiferal Res. Contrib., 2:77-81.

1928. Additional foraminifera from the upper Eocene of Alabama. Cushman Lab. Foraminiferal Res. Contrib., 4:73-79.

, 1933. Some new foraminiferal genera. Cushman Lab. Foraminiferal Res. Contrib., 9:32-38.

1938. Cretaceous species of Guembelina and related genera. Cushman Lab. Foraminiferal Res. Contrib., 14:2-28.

1940. Midway foraminifera from Alabama. Cushman Lab. Foraminiferal Res. Contrib., 16:51-73.

1946. Upper Cretaceous foraminifera of the Gulf Coastal Region of the United States and adjacent areas. Geol. Surv. Prof. Pap. U.S., 206:1-241.

Cushman, J. A., and Bermúdez, P. J., 1937. Further new species of foraminifera from the Eocene of Cuba. Cushman Lab. Foraminiferal Res. Contrib., 13:1-29.

1949. Some Cuban species of Globorotalia. Cushman Lab. Foraminiferal Res. Contrib., 25:26-45.

Cushman, J. A., and Ellisor, A. C., 1939. New species of foraminifera from the Oligocene and Miocene. Cushman Lab. Foraminiferal Res. Contrib., 15:1-14.

Cushman, J. A., and Hanna, G. D., 1927. Foraminifera from the Eocene near San Diego, California.Trans. San Diego Soc. Nat. Hist., 5:45-64.
Cushman, J. A., and Ponton, G. M., 1932a. An Eocene foraminiferal fauna of Wilcox age from Alabama. Cushman Lab. Foraminiferal Res. Contrib., 8:51-72.

$1932 \mathrm{~b}$. The foraminifera of the upper, middle and part of the lower Miocene of Florida. Florida Geol. Surv. Geol. Bull., 9:7-147.

Cushman, J. A., and Renz, W. H., 1942. Eocene, Midway, foraminifera from Soldado Rock, Trinidad. Cushman Lab. Foraminiferal Res. Contrib., 18:1-20.

Cushman, J. A., and Ten Dam, A., 1948. Globigerinelloides, a new genus of the Globigerinidae. Cushman Lab. Foraminiferal Res. Contrib., 24:42-43.

Dalbiez, F., 1955. The genus Globotruncana in Tunisia. Micropaleontology, 1:161-171.

Davies, T. A., Luyendyk, B. P., et al., 1974. Init. Repts., DSDP, 26: Washington (U.S. Govt. Printing Office).

de Klasz, I., 1953a. Einige neue oder wenig bekannte Foraminiferen aus der helvetischen Oberkreide der bayerischen Alpen südlich Traunstein (Oberbayern). Geol. Bav., 17:223-239.

1953b. On the foraminiferal genus Gublerina Kikoine. Geol. Bav., 17:245-249.

Delage, Y., and Herouard, E., 1896. Traité de Zoologie Concrete. Tome I: La Cellule et les Protozoaires: Paris (Schleicher, Frères et cie).

de Lapparent, J., 1918. Etude lithologique des terrains Crétacés de la région d'Hendaye. Mém. Pour Servir a l'Explication de la Carte Géologique de la France: Paris (Impr. Nat.).

d'Orbigny, A. D., 1826. Tableau méthodique de la classe des céphalopodes. Annales Sci. Nat. Paris, Ser. 1, 7:95-314.

1839. Foraminiferes. In de la Sagra, R. (Ed.), Histoire Physique, Politique et Naturelle de l'Ile de Cuba: Bertrand (Paris).

1840. Mémoire sur les foraminifères de la craie blanche de bassin de Paris. Soc. Geol. Fr, Paris, 4:1-51.

Douglas, R. G., and Rankin, C., 1969. Cretaceous planktonic foraminifera from Bornholm and their zoogeographic significance. Lethaia, 2:185-217.

Egger, J. G., 1893. Foraminiferen aus Meeresgrundproben gelohtet von 1874 bis 1876 vom S. M. Sch. "Gazelle." Abh. Bayerische Akad. Wiss., Math.-Physik. Kl., 18:193-458.

1899. Foraminiferen und Ostrakoden aus den Kreidemergeln der Oberbayerischen Alpen. Abh. Bayerischen Akad. Wiss., Math.Physik. Kl., 21:1-230.

Ehrenberg, C. G., 1840. Die Bildung der Europäischen, Lybischen und Arabischen Kreidefelsen und des Kreidemergels aus mikroskopischen Organismen. Abh. Preuss. Akad. Wiss. Berlin Physik.-Math. Kl., (1838), 59-147.

1843. Verbreitung und Einfluss des mikroskopischen Lebens in Süd- und Nord-Amerika. Abh. Preuss. Akad. Wiss. Berlin Physik.Math. Kl., 4:291-446.

1854. Mikrogeologie; das Erden und Felsen Schaffende Wirken des Unsichtbar Kleines Selbständigen Lebens auf der Erde: Leipzig (Leopold Voss).

1861. Elemente des tiefen Meeresgrundes in Mexikanischen Golfstrome bei Florida; Ueber die Tiefgrund-Verhältnisse des Oceans am Eingang der Davisstrasse und bei Island. Kon. Preuss. Akad. Wiss. Berlin Monatsber. Berlin, 222-240, 275-315.

El Naggar, Z. R., 1966. Stratigraphy and planktonic foraminifera in the Upper Cretaceous-lower Tertiary succession in the Esna-Idfu region, Nile Valley, Egypt, U.A.R. London Br. Mus. (Nat. Hist). Bull. Geol., Suppl., 2:1-291.

Finlay, H. J., 1939a. New Zealand foraminifera; key species in stratigraphy, no. 2. Trans. R. Soc. N.Z., 69:89-128.

1939 b. New Zealand foraminifera; key species in stratigraphy, no. 3. Trans. R. Soc. N.Z., 69:309-329.

1947. New Zealand foraminifera; key species in stratigraphy, no. 5. N.Z. J. Sci. Tech., Sec. B, 28:259-292.

Fleisher, R. L., 1974. Cenozoic planktonic foraminifera and biostratigraphy, Arabian Sea, Deep Sea Drilling Project, Leg 23A. In Whitmarsh, R. B., Weser, O. E., Ross, D. A., et al., Init. Repts. DSDP, 23: Washington (U.S. Govt. Printing Office), 1001-1072.

Gandolfi, R., 1955. The genus Globotruncana in northeastern Colombia. Bull. Am. Paleontol., 36:7-118.

Glaessner, M. F., 1937. Planktonforaminiferen aus der Kreide und dem Eocän und Ihre Stratigraphische Bedeutung. Etyudy Mikropaleontol, Moskow Univ., 1:27-52. 
Govindan, A., 1972. Upper Cretaceous planktonic foraminifera from the Pondicherry area, South India. Micropaleontology, 18:160-193.

Guembel, C. W., 1868. Beiträge zur Foraminiferenfauna der nordalpinen älteren Eocängebilde oder der Kressenberger Nummulitenschichten. Abh. Bayerischen Akad. Wiss., Math.-Physik. Kl., 10:579-730.

Hagn, H., and Lindenberg, H. G., 1966. Revision of Globigerina (Subbotina) eocaena Guembel from the Eocene of the Bavarian Alps. Akad.Nauk. SSSR Voprosy Mikropaleontol., 10:342-350. (in Russian)

Hayes, D. E., Frakes, L. A., et al., 1975. Init. Repts. DSDP, 28: Washington (U.S. Govt. Printing Office).

Hedberg, H. D., 1937. Foraminifera of the middle Tertiary Carapita Formation of northeastern Venezuela. J. Paleontol., 11:661-697.

Herb, R., 1974. Cretaceous planktonic foraminifera from the eastern Indian Ocean. In Davies, T. A., Luyendyk, B. P., et al., Init. Repts. DSDP, 26: Washington (U.S. Govt. Printing Office), 745-770.

Hofker, J., Sr., 1956. Die Globotruncanen von Nordwest-Deutschland und Holland. Neues Jahrb. Geol. Paleontol. Abh., 103:312-340.

Hornibrook, N. de B., 1965. Globigerina angiporoides n. sp. from the upper Eocene and lower Eocene of New Zealand and the status of Globigerina angipora Stache, 1865. N.Z. J. Geol. Geophys., 8:834838 .

Howe, H. V., 1928. An observation on the range of the genus Hantkenina. J. Paleontol., 2:13-14.

1939. Louisiana Cook Mountain Eocene foraminifera. Bull. Louisiana Geol. Surv., 14:1-122.

Howe, H. V., and Wallace, W. E., 1932. Foraminifera of the Jackson Eocene at Danville Landing on the Ouachita, Catahoula Parish, Louisiana. Louisiana Dept. Conserv. Geol. Bull., 2:18-79.

Huber, B. T., 1990. Maestrichtian planktonic foraminifer biostratigraphy of the Maud Rise (Weddell Sea, Antarctica): ODP Leg 113 \#.jles 689B and 690C. In Barker, P. F., Kennett, J. P., et al., Proc. ODP, Sci. Results, 113: College Station, TX (Ocean Drilling Program), 489513.

Jenkins, D. G., 1960. Planktonic foraminifera from the Lakes Entrance oil shaft, Victoria, Australia. Micropaleontology, 6:345-371.

1966. Planktonic foraminiferal zones and new taxa from the Danian to lower Miocene of New Zealand. N.Z. J. Geol. Geophys., 8:1088-1126.

1977. Lower Miocene planktonic foraminifera from a bore-hole in the English Channel. Micropaleontology, 23:297-318. 1985. Southern mid-latitude Paleocene to Holocene planktic foraminifera. In Bolli, H. M., Saunders, J. B., and Perch-Nielsen, K. (Eds.), Plankton Stratigraphy: Cambridge (Cambridge Univ. Press), 263-282.

Kaneps, A. G., 1975. Cenozoic planktonic foraminifera from Antarctic deep-sea sediments, Leg 28, DSDP. In Hayes, D. E., Frakes, L. A., et al., Init. Repts. DSDP, 28: Washington (U.S. Govt. Printing Office), 573-584.

Keller, B. M., 1946. Foraminifera from the Upper Cretaceous deposits of the Sotchi region. Byull. Mosk. Obstch. Ispyt. Prir. n.s., 51 (Sect. Geol.), 23:83-108.

Keller, G., 1983. Biochronology and paleoclimatic implications of middle Eocene to Oligocene planktonic foraminiferal faunas. Mar. Micropaleontol., 7:463-468.

Kennett, J. P., 1982. Marine Geology: Englewood Cliffs, NJ (Prentice Hall).

Kennett, J. P., and Srinivasan, M. S., 1983. Neogene Planktonic Foraminifera: A Phylogenetic Atlas: Stroudsburg, PA (Hutchinson Ross).

Kikoine, J., 1948. Les Heterohelicidae du Crétacé supérieur pyreneen. Bull. Geol.Soc. Fr., Ser. 5, 18:15-35.

Koch, R. E., 1926. Mitteltertäire foraminiferen aus Bulongan, Ost-Borneo. Eclogae Geol. Helv., 19:722-751.

1935. Namensänderung einiger Tertiär-Foraminiferen aus Niederländisch Ost-Indien. Eclogae Geol. Helv., 28:557-558.

Kroon, D., and Nederbragt, A. J., in press. Ecology and paleoecology of triserial planktic foraminifera. Mar. Micropaleontol.

Lalicker, C. G., 1948. A new genus of foraminifera from the Upper Cretaceous. J. Paleontol., 22:624.

LeRoy, L. W., 1939. Some small foraminifera, ostracoda and otoliths from the Neogene ("Miocene") of the Rokan-Tapanoeli area, Central Sumatra. Natuurk. Tijdschr. Nederl. Indië, 99:214-296.

1953. Biostratigraphy of the Maqfi section, Egypt. Mem. Geol. Soc. Am., 54:1-73
Lipps, J. H., 1964. Miocene planktonic foraminifera from Newport Bay, California. Tulane Stud. Geol., 2:109-133.

Loeblich, A. R., and Tappan, H., 1956. Chiloguembelina, a new Tertiary genus of the Heterohelicidae, (Foraminifera). Wash. Acad. Sci. J., 46:340.

1957. Planktonic foraminifera of Paleocene and early Eocene age from the Gulf and Atlantic coastal plains. Bull. U.S. Nat. Mus., 215:173-198.

1961. Cretaceous planktonic foraminifera; part $1-$ Cenomanian. Micropaleontology, 7:257-304.

Luyendyk, B. P., 1977. Deep sea drilling on the Ninetyeast Ridge: synthesis and a tectonic model. In Heirtzler, J. R., Bolli, H. M., Davies, T. A., Saunders, J. B., and Sclater, J. G. (Eds.), Indian Ocean Geology and Biostratigraphy: Washington (Am. Geophys. Union), 165-187.

Luyendyk, B. P., and Rennick, W., 1977. Tectonic history of aseismic ridges in the eastern Indian Ocean. Geol. Soc. Am. Bull., 88:13471356.

Marie, P., 1941. Les foraminiferes de la Craie a Belemnitella mucronata du bassin de Paris. Mem. Mus. Nat. Hist. Paris, 12:237-258.

Martin, L. T., 1943. Eocene foraminifera from the type Lodo Formation, Fresno County, California. Stanford Univ. Publ. Geol. Sci., 3:93-125.

Martin, S. E., 1972. Re-examination of the Upper Cretaceous planktonic foraminiferal genera Planoglobulina Cushman and Ventilabrella Cushman. J. Foraminiferal Res., 2:73-92.

Masters, B. A., 1977. Mesozoic planktonic foraminifera, a world-wide review and analysis. In Ramsay, A.T.S. (Ed.), Oceanic Micropaleontology: London (Academic Press), 1:301-732.

McGowran, B., 1968. Reclassification of early Tertiary Globorotalia. Micropaleontology, 14:179-198.

1974. Foraminifera. In von der Borch, C. C., Slater, J. G., et al., Init. Repts. DSDP, 22: Washington (U.S. Govt. Printing Office), 609-627.

Montanaro Gallitelli, E., 1957. A revision of the foraminiferal family Heterohelicidae. Bull. U.S. Nat. Mus., 215:133-154.

Morgan, W. J., 1981. Hotspot tracks and the opening of the Atlantic and Indian oceans. In Emiliani, C. (Ed.), The Sea (vol. 7): New York (Wiley), 443-487.

Mornod, L., 1949-1950. Les Globorotalides de Crétacé supérieur du Montsalvens (Préalpes Fribourgeoises). Eclogae Geol. Helv., 596.

Morozova, V. G., 1939. On the stratigraphy of the Upper Cretaceous and Paleogene of the Emba region according to the foraminiferal faunas. Byull.Mosk. Obshch. Ispyt. Prir. n.s., (Sect. Geol., 17), 47:59-86. (in Russian)

1957. Foraminiferal superfamily Globigerinidea, superfam. nov., and some of its representatives. Akad. Nauk. SSSR Doklady, 114:1109-1111. (in Russian)

1961. Planktonic foraminifers from the Danian-Montian of the southern Soviet Union. Akad. Nauk. SSSR Paleontol. Zhur., 2:8-19. (in Russian)

Mutter, J. C., and Cande, S. C., 1983. The early opening between Broken Ridge and Kerguelen Plateau. Earth Planet. Sci. Lett., 65:369-376.

Myatliuk, E. V., 1950. The stratigraphy of the flysch deposits of the northern Carpathian Mountains according to the foraminiferal fauna's. Trudy VNIGRI, n. ser., 51:225-287. (Microfauna of the USSR, 4 , in Russian)

Natland, M. L., 1938. New species of foraminifera from off the West Coast of North America and from the later Tertiary of the Los Angeles Basin. California Univ. Inst. Oceanogr. Bull. Tech. Ser., 4:137-164.

Nederbragt, A. J., 1989. Chamber proliferation in the Cretaceous planktonic foraminifera Heterohelicidae. J. Foraminiferal Res., 19:105114.

1990. Maastrictian Heterohelicidae (planktonic foraminifera) from the North West Atlantic. J. Micropaleontol., 8:183-206.

in press. Biostratigraphy and development of Late Cretaceous Heterohelicidae (planktic foraminifera). Mar. Micropaleontol.

Nuttall, W.L.F., 1930. Eocene foraminifera from Mexico. J. Paleontol., $4: 271-293$.

Olsson, R., 1960. Foraminifera of latest Cretaceous and earliest Tertiary age of the New Jersey coastal plain. J. Paleontol., 34:1-58. 1964. Late Cretaceous planktonic foraminifera from New Jersey and Delaware. Micropaleontology, 10:157-188. 
Palmer, D. K., 1934. The foraminiferal genus Gümbelina in the Tertiary of Cuba. Mem. Soc. Cubana Hist. Nat., 8:73-76.

1940. Foraminifera of the upper Oligocene Cojimar Formation of Cuba, part 3. Mem. Soc. Cubana Hist. Nat., 14:277-304.

Parr, W. J., 1938. Upper Eocene foraminifera from deep borings in King's Park, Perth, Western Australia. J. R. Soc. West. Australia, 24:69-101.

Pessagno, E. A., 1960. Stratigraphy and micropaleontology of the Cretaceous and lower Tertiary of Puerto Rico. Micropaleontology, 6:87110 .

1967. Upper Cretaceous planktonic foraminifera from the western Gulf Coastal Plain. Palaeontogr. Amer., 5:245-445.

Pessagno, E. A., and Fouad, Y. M., Jr., 1974. Mesozoic foraminifera, Leg 22, Site 217. In von der Borch, C. C., Sclater, J. G., et al., Init. Repts. DSDP , 22: Washington (U.S. Govt. Printing Office), 629-634.

Pijpers, P. J., 1933. Geology and paleontology of Bonaire (D.W.I.). Univ. Utrecht Geol. Med., Phys.-Geol. Reeks, 8:1-103.

Plummer, H. J., 1926. Foraminifera of the Midway Formation in Texas. Texas Univ. Bull., 2644.

Pokorný, V., 1955. Cassigerinella boudecensis n. gen., n. sp. (Foraminifera, Protozoa) from the Oligocene of the Zdanice Flysch. Ustred. Ustav. Geol. Vestnik., 30:136-140.

Porthauld, B., 1970. Le Sénonien inférieur de Puget-Theniers (AlpesMaritimes) et sa microfaune. In Donze, P., Porthauld, B., Thomel, G., and de Villeoutreys, O. (Eds.), Geobios, 3:41-106.

Postuma, J. A., 1971. Manual of Planktonic Foraminifera: Amsterdam (Elsevier).

Quilty, P. G., 1976. Planktonic foraminifera, DSDP Leg 34. In Yeats, R. S., Hart, S. R., et al., Init. Repts. DSDP, 34: Washington (U.S. Govt. Printing Office), 629-703.

Reiss, Z., 1957. The Bilamellidae, nov, superfam. and remarks on Cretaceous Globorotaliids. Cushman Found. Foraminiferal Res. Contrib., $8: 27-152$.

Renz, H. H., 1948. Stratigraphy and fauna of the Agua Salada Group, State of Falcón, Venezuela. Mem. Geol. Soc. Am., 32:1-219.

Reuss, A. E., 1850. Neue Foraminiferen aus den Schichten des Oesterreichischen Tertiärbeckens. Sitzaber. K. Akad. Wiss., Wien, Math. Naturw., Kl., Denkschrift, 1:365-390.

1854. Beiträge zur charakteristik der Kreide-Schichten in der Ostalpen, besonders in Gosauthale und aus Wolfgangsee. Sitzaber. Kon. Akad. Wiss., Wien, Math.-Naturw., Kl., Denkschrift, 7:1-156.

Robaszynski, F., and Caron, M. (Coordinators), 1979. Atlas de Foraminifères Planctoniques du Crétacé Moyen (vols. 1 and 2). Cah. Micropaleontol.

Robaszynski, F., Caron, M., Gonzales Donoso, J. M., and Wonders, A.A.H., 1984. Atlas of Late Cretaceous planktonic foraminifera. Rev. Micropaleontol., 26:145-305.

Rzehak, A., 1891. Die Foraminiferenfauna der alttertiären Ablagerungen von Bruderndorf in Nieder-Oesterreich, mit Berücksichtigung des angeblichen Kreidevorkommens von Leitzerdorf. Annln. Naturh. Mus. Wien, 6:1-12

Scheibnerova, V., 1962. Stratigraphy of the Middle and Upper Cretaceous of the Mediterranean province on the basis of the Globotruncanids. Geol. Sb. Bratislava, 13:197-226.

Schwager, C., 1883. Die Foraminiferen aus den Eocän-Ablagerungen der Lybischen Wüste und Aegyptens. Palaeontographica, 30:79-154.

Shutskaya, E. K., 1958. Variations of some lower Paleogene planktonic foraminifera of the northern Caucasus. Akad. Nauk. SSSR Voprosy Mikropaleontol., 2:84-90. (in Russian)

Sliter, W. V., 1977. Cretaceous foraminifers from the southwestern Atlantic Ocean, Leg 36, Deep Sea Drilling Project. In Barker, P., Dalziel,
I.W.D., et al., Init. Repts, DSDP, 36: Washington (U.S. Govt. Printing Office), 519-574.

Smit, J., 1977. Discovery of a planktonic foraminiferal association between the Abathomphalus mayaroensis Zone and the Globigerina eugubina Zone at the Cretaceous/Tertiary boundary in the Barranco del Gredero (Caravaca, SE Spain); a preliminary report I and II. Proc. K. Ned. Akad. Wet., Ser. B, 80:280-301.

Smith, C. C., and Pessagno, E. A., 1973. Planktonic foraminifera and stratigraphy of the Corsicana Formation (Maestrichtian), North-Central Texas. Cushman Found. Foraminiferal Res. Spec. Publ., 12:5-68.

Srinivasan, M. S., and Kennett, J. P., 1976. A planktonic foraminifer (Clavatorella) from the Pliocene. J. Foraminiferal Res., 4:77-79.

Stainforth, R. M., Lamb, J. L., Luterbacher, H. P., Beard, J. H., and Jeffords, R. M., 1975. Cenozoic planktonic foraminiferal zonation and characteristics of index forms. Univ. Kans. Paleontol. Contrib. Art., 62:1-425.

Stenestad, E., 1968. Three new species of Heterohelix Ehrenberg from the upper Senonian of Denmark. Medd. Dan. Geol. Foren., 18:64-70.

Subbotina, N. N., 1947. Foraminifers of the Danian and Paleogene deposits of the northern Caucasus. Microfauna of the Caucasus, Emba region and central Asia. (Mikrofauna Kavkasa, Emby i Sredni Azii, Lengostoptekhizdat). Trudy VNIGRI, 39-160. (in Russian)

1950. Microfauna and stratigraphy of the Elburgian horizon and the horizon of Goriatchii Klintch. In Microfauna of the USSR 4. Trudy VNIGRI, n. ser., 51:5-112. (in Russian)

1953. Fossil Foraminifera of the USSR: Globigerinidae, Hantkeninidae and Globorotaliidae. Trudy VNIGRI, n. ser., 76. (in Russian). (London) Collet's. (transl. by E. Lees)

Tappan, H., 1940. Foraminifera from the Grayson Formation of northern Texas. J. Paleontol., 14:93-126.

Thalmann, H. E., 1942. Foraminiferal genus Hantkenina and its subgenera. Am. J.Sci., 240:809-820.

Tilev, N., 1951. Etude des Rosalines maestrichtiennes (genre Globotruncana) du Sud-Est de la Turquie (sondage de Ramandag). Madan. Tetkik Arama Enst. Yayin., Seri. B, 16:1-101.

Todd, R., 1970. Maestrichtian (Late Cretaceous) foraminifera from a deep-sea core off southwestern Africa. Rev. Esp. Micropaleontol., 2:131-154.

Toulmin, L. D., 1941. Eocene smaller foraminifera from the Salt Mountain Limestone of Alabama. J. Paleontol., 15:567-611.

Toumarkine, M., and Bolli, H. M., 1970. Evolution de Globorotalia cerroazulensis (Cole) dans l'Eocène moyen et supérieur de Possagno (Italie). Rev. Micropaleontol., 13:131-145.

Toumarkine, M., and Luterbacher, H., 1985. Paleocene and Eocene planktic foraminifera. In Bolli, H. M., Saunders, J. B., and Perch-Nielsen, K. (Eds.), Plankton Stratigraphy: Cambridge (Cambridge Univ. Press), 87-154.

van Hinte, J. E., 1963. Zur stratigraphie und mikropaläontologie der Oberkreide und des Eocäns des Krappfeldes (Kärnten). Jahrb. Geol. Bundensanst Austria, 8:1-147.

Voorwijk, G. H., 1937. Foraminifera from the Upper Cretaceous of Havana, Cuba. K. Ned. Akad. Wet., Proc. Sec. Sci., 40:190-198.

White, M. P., 1928. Some index foraminifera of the Tampico Embayment area, Mexico. J. Paleontol., 2:177-215, 280-317.

Date of initial receipt: 26 February 1990

Date of acceptance: 6 December 1990

Ms 121B-150 


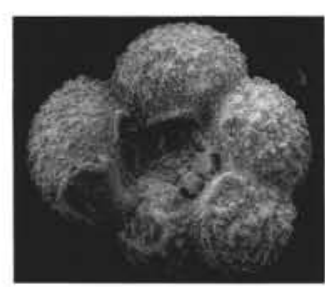

1

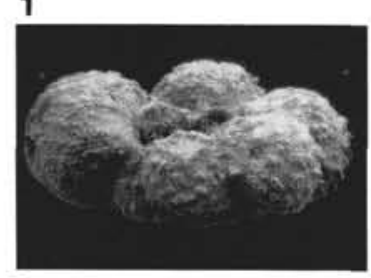

5

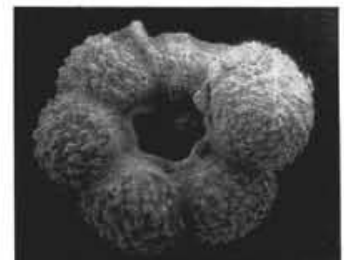

9

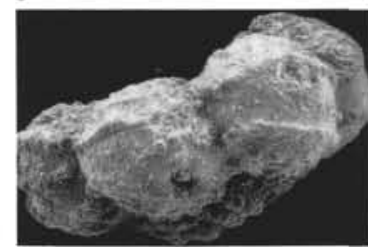

13

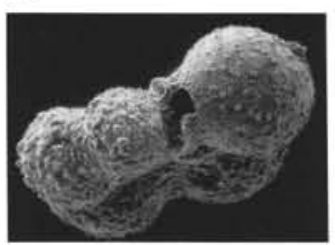

17

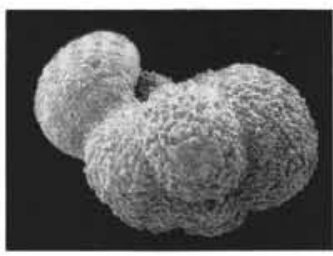

2

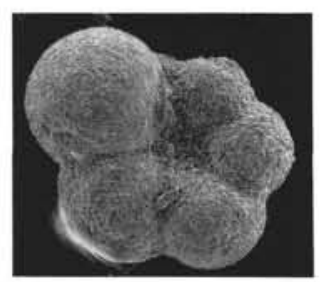

6

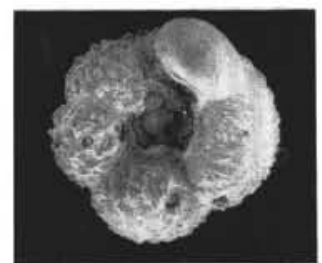

10

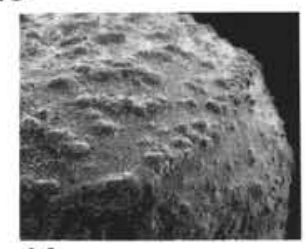

14

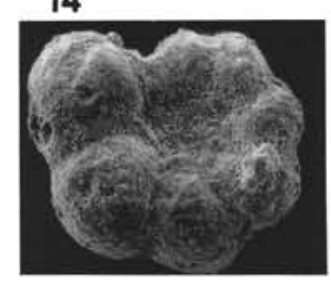

18

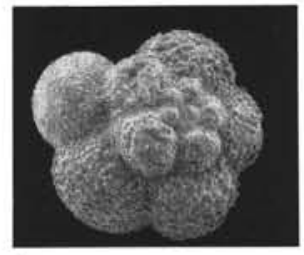

3

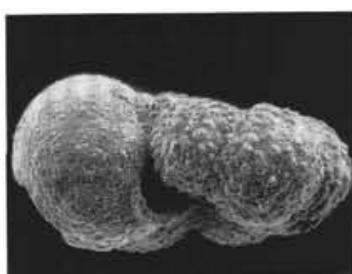

7

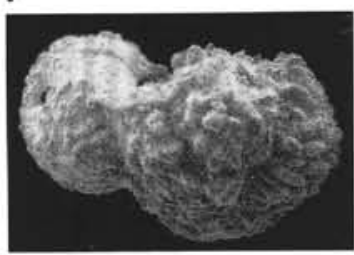

11

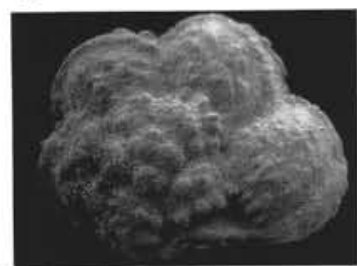

15

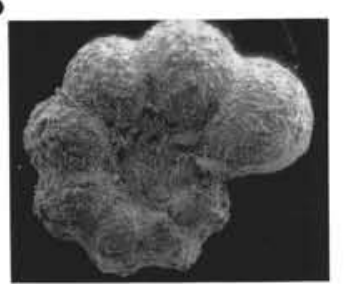

19

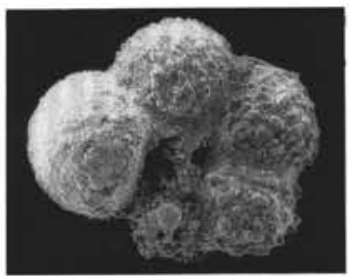

4

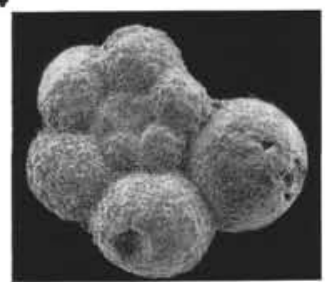

8

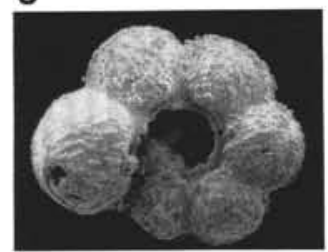

12

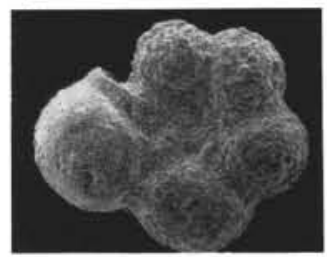

16

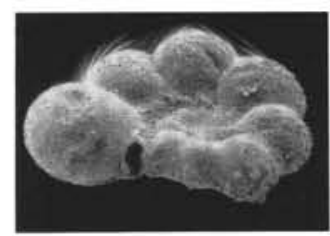

20

Plate 1. 1-3. Archaeoglobigerina australis Huber, 1990. Fig. 1. Umbilical view, note absence of tegillum. Sample 121-758A-31X-CC, 60X. Fig. 2. Side view. Sample 121-758A-31X-CC, 80×. Fig. 3. Spiral view, Sample 121-758A-46R-CC, 30-34 cm, 60×. 4, 5. Archaeoglobigerina cretacea (d'Orbigny, 1840) specimens with tendency toward Rugoglobigerina hexacamerata Brönnimann, 1952a. Fig. 4. Umbilical view, note poorly developed tegillum. Sample 121-754A-21N-1, 71-74 cm, 70x. Fig. 5. Side view, Sample 121-754A-20N-2, 113-118 cm, 60×. 6-8. Hedbergella sp. cf. H. planispira (Tappan, 1940). Fig. 6. Umbilical view, Sample 121-752B-16R-CC, 90x. Fig. 7. Side view, Sample 121-754A-21N-1, 71-74 cm, 160x. Fig. 8. Spiral view, Sample 121-752B-12R-4, 90-93 cm, 100x. 9. Rugoglobigerina pennyi Brönnimann, 1952a. Note absence of tegillum and slightly aligned costellae. Sample 121-752B-19R-CC, 60X. 10, 11. Rugoglobigerina rugosa (Plummer, 1926), Sample 121-758A-31X-CC. Fig. 10. Umbilical view, note absence of tegillum and unomamented abortive final chamber, 60x. Fig. 11. Side view, 80x. 12-15. Rugotruncana subcircumnodifer Gandolfi, 1955. Fig. 12. Weakly ornamented specimen, Sample 121-752B-16R-CC, 40x. Fig. 13. Side view, showing keels and unperforated peripheral band. Sample 121-752B-16R-CC, 60x. Fig. 14. Detail of final chamber, showing wall structure. Sample 121-754A-21N-1, 71-74 cm, 160×. Fig. 15. Spiral view, showing aligned costellae. Sample 121-752B-16R-CC, 60×. 16, 17. Globigerinelloides volutus (White, 1928). Fig. 16. Umbilical view, Sample 121-754B-13R-CC, 140×. Fig. 17. Side view, Sample 121- 758A-41X-CC, 160×. 18-20. Globigerinelloides yaucoensis Pessagno, 1960 group. Fig. 18. Specimen from the Coniacian, note similarity with Figure 19. Sample 121-755A-10R-1, 114-117 cm, 120x. Fig. 19. Maestrichtian specimen, Sample 121-758A-36X-CC, 120x. Fig. 20. Side view, Sample 121-758A-36X-CC, 120x. 

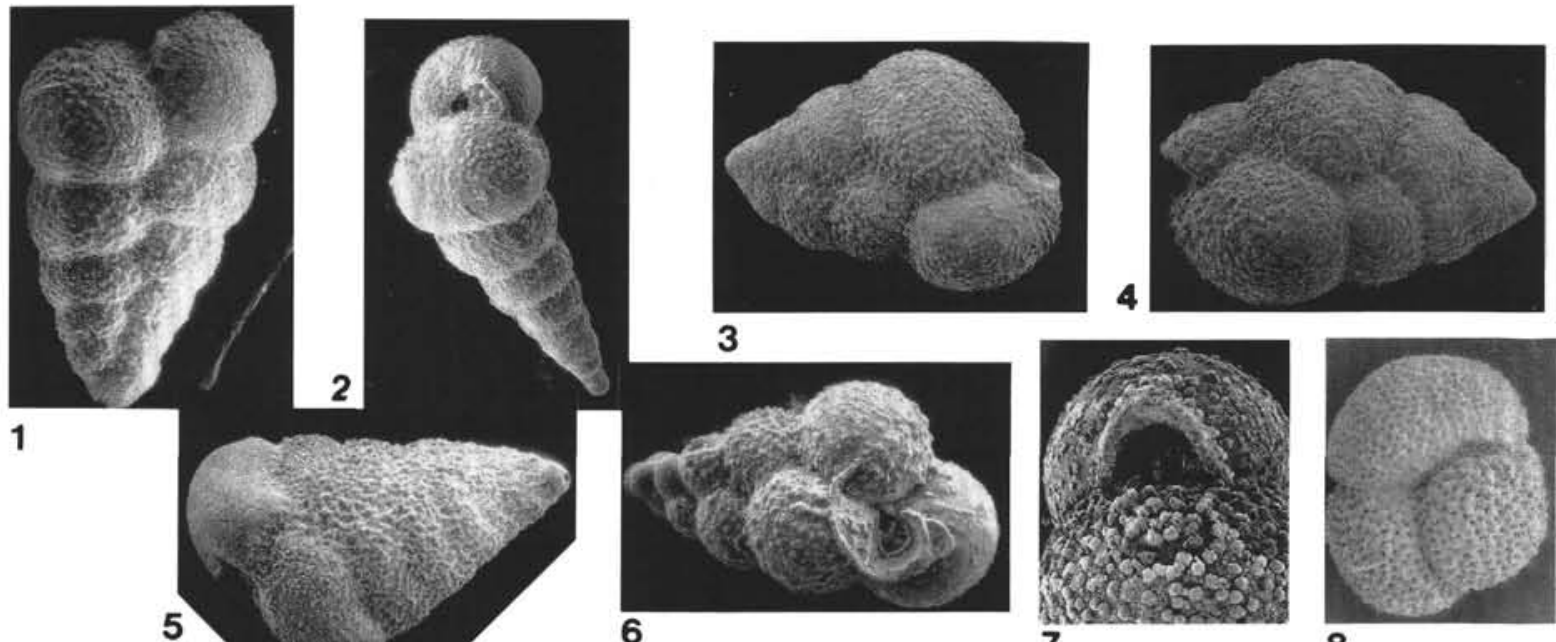

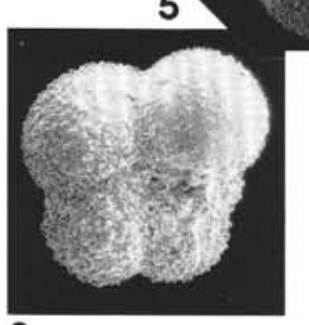

9
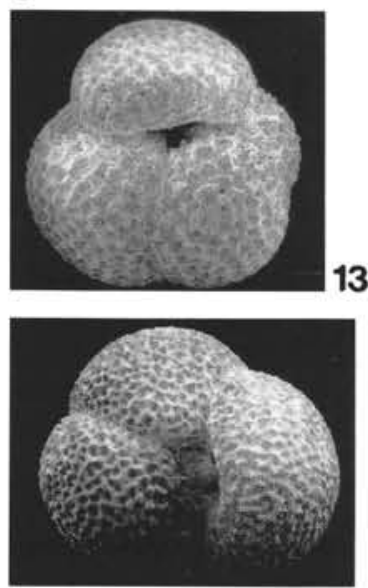

17

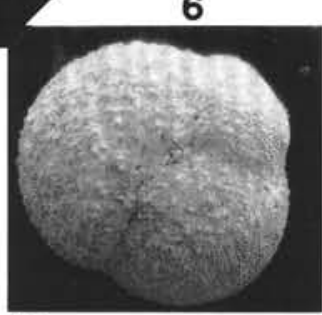

10

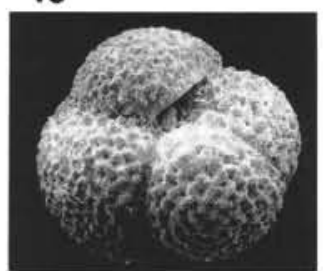

14

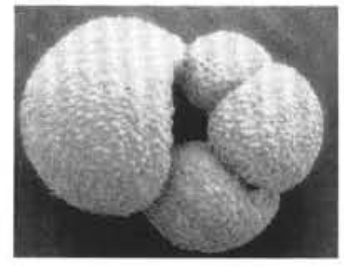

18

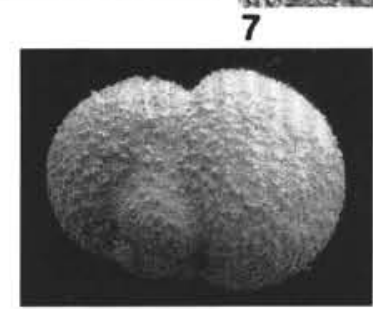

11

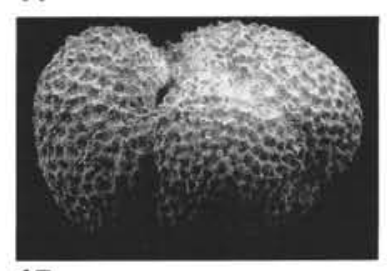

15

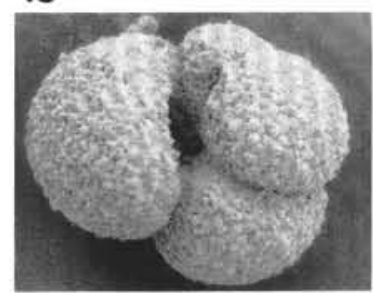

19
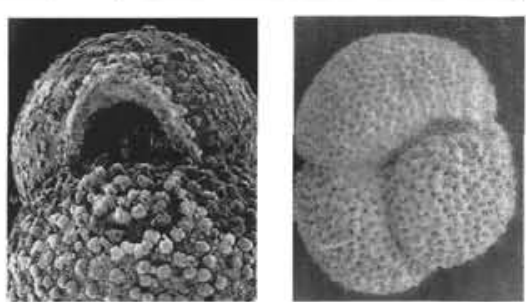

8
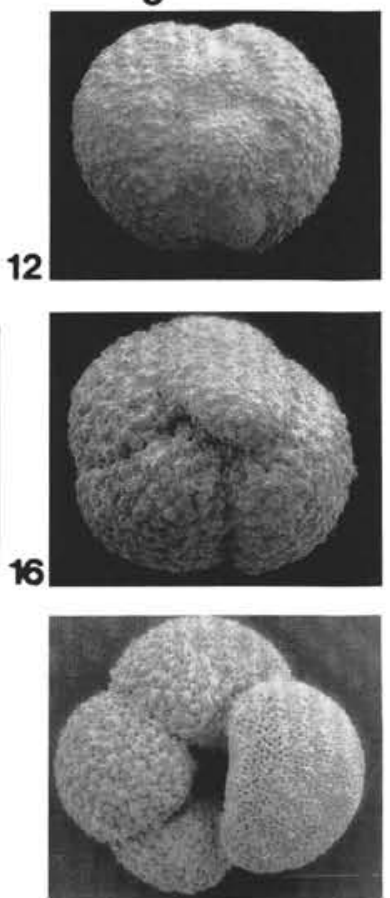

20

Plate 2. 1, 2. Chiloguembelina cubensis (Palmer, 1934) Fig. 1. Sample 121-756C-5X-CC, 220x. Fig. 2. Slender, somewhat twisted specimen, Sample 121-756C-5X-CC, 140×. 3, 4, 7. Chiloguembelina wilcoxensis (Cushman and Ponton, 1932a). Fig. 3. Well-developed, large specimen, Sample 121-752A-14X-3, 110-115 cm, 60x. Fig. 4. Small specimen with aberrant final chamber, Sample 121-752A-15X-CC, 110x. Fig. 7. Detail of aperture, Sample 121-752A-14X-3, 110-115 cm, 140×. 5. Chiloguembelina subtriangularis Beckmann, 1957, Sample 121-753A-7H-CC, 200×. 6. Guembelitria columbiana Howe, 1939, Sample 121-753A-7H-CC, 280x. 8. Globigerina angiporoides Hornibrook, 1965, Sample 121-756C-5X-CC, 80×. 9. Globigerina angustiumbilicata Bolli, 1957a. Specimen with four chambers in the final whorl and a somewhat extraumbilical aperture. Sample $121-758 \mathrm{~A}-21 \mathrm{X}-1,128-133 \mathrm{~cm}, 140 \times$. 10-12. Globigerina sp. "bipartita." Fig. 10. Umbilical view of a specimen with a relatively large antepenultimate chamber. Sample $121-758 \mathrm{~A}-23 \mathrm{X}-4,115-119 \mathrm{~cm}, 30 \times$. Fig. 11 . Side view of an elongate specimen, Sample 121-758A-22X-2,115-120 cm, 30x. Fig. 12. Spiral view. Note very small, bullalike, abortive final chamber. Sample 121-758A-23X-4, $115-119 \mathrm{~cm}, 30 \times .13-16$. Globigerina euapertura Jenkins, 1960. Fig. 13. Specimen closely referable to the original description, Sample 121-756B-8H-1, 110-115 cm, 60x. Fig. 14. Specimen with aberrant final chamber, Sample 121-756B-10H-1, 110-115 cm, 60x. Fig. 15. Side view, Sample 121-754A-12H-CC, 60x. Fig. 16. Globigerina sp. or Catapsydrax sp. Sample 121-757B-15H-CC, 60x. Fig. 17. Globigerina galavisi Bermúdez, 1960, Sample 121-756B-10H-1, 110-115 cm, 50x. 18-20. Globigerina praebulloides Blow, 1959. Fig. 18. Normal specimen, Sample 121-756B-8H-2, 110-115 cm, 80x. Fig. 19. More compact specimen, Sample 121-756B-8H-2, 110-115 cm, 80x. Fig. 20. Specimen resembling $G$. euapertura Jenkins, 1960, Sample 121-756B-8H-2, 110-115 cm, 80x. 


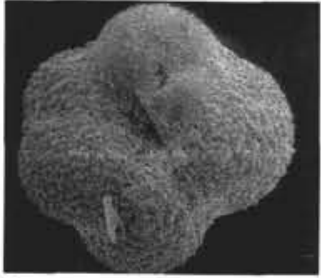

1

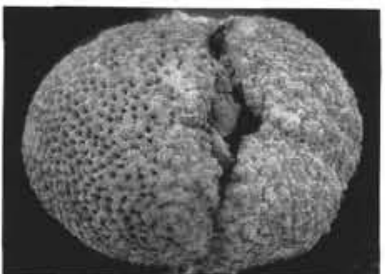

5

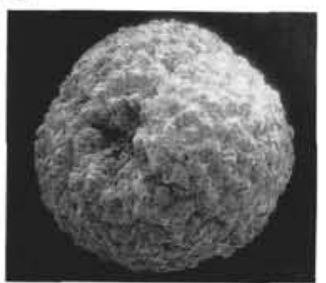

9

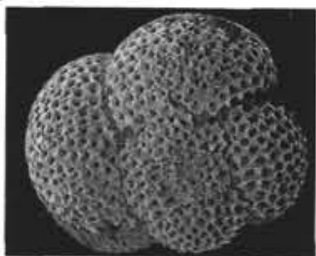

13

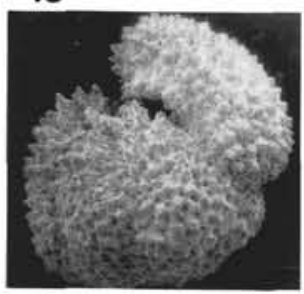

17

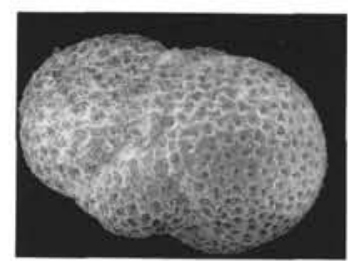

2

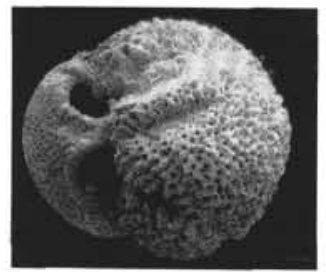

6

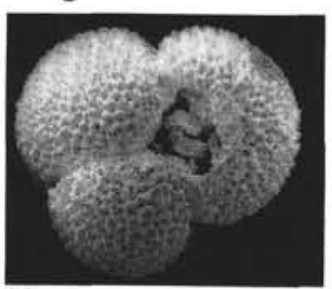

10

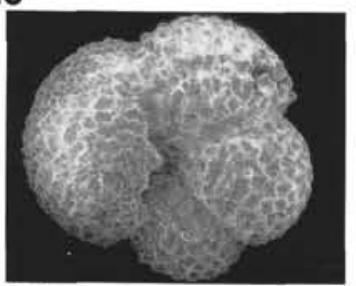

14

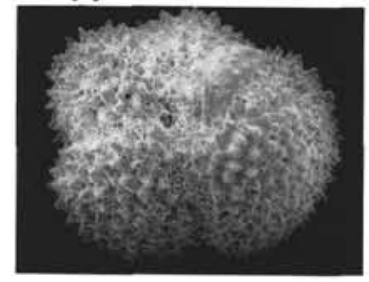

18

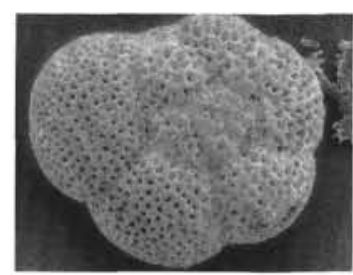

3

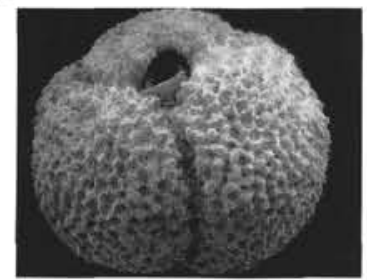

7

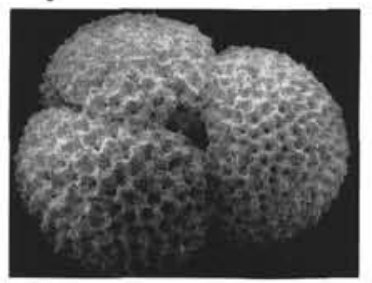

11

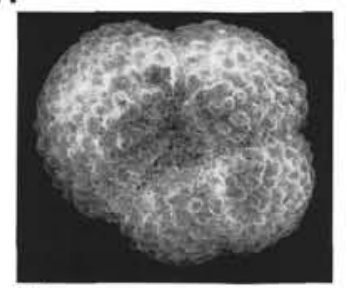

15

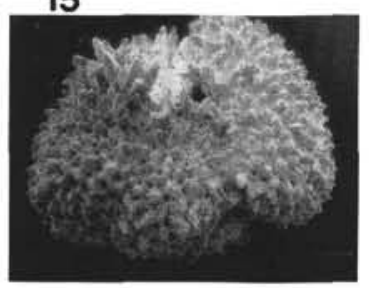

19

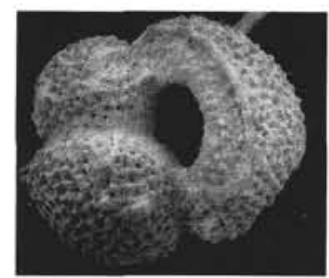

4

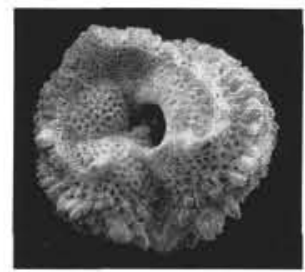

8

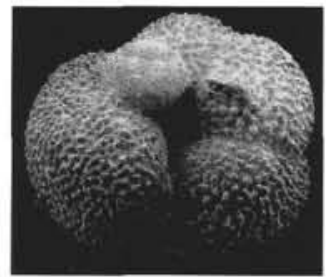

12

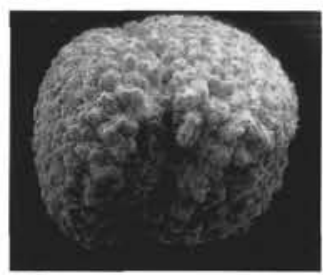

16

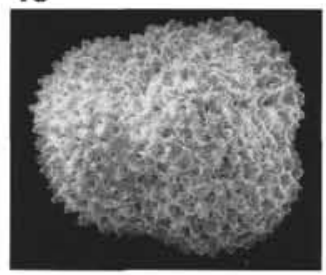

20

Plate 3. 1-3. Globigerina sp. cf. G. quinqueloba Natland, 1938, Sample 121-758A-21X-2, 126-131 cm, 140×. Fig. 1. Umbilical view. Fig. 2. Side view. Fig. 3. Spiral view. 4, 5, 9. Globigerinatheka sp. cf. G. index (Finlay, 1939a). Fig. 4. Typical specimen with inflated chambers and depressed sutures, Sample 121-754A-14X-3, 110-115 cm, 80x. Fig. 5. Compact specimen with cleftlike sutures, Sample 121-752A-11H-CC, 60X. Fig. 9. Very compact specimen, Sample 121-752A-11H-CC, 60×. 6-8. Globigerinatheka index (Finlay, 1939a), Sample 121-752A-11H-CC, 60×. Fig. 6. Typical specimen. Fig. 7. Specimen with small final chamber. Fig. 8. Broken specimen, showing juvenile "cf. G. index" stage. Compare with Figure 4. 10. Globigerinoides altiaperturus Bolli, 1957a, Sample 121-757B-11H-2, 110-115 cm, 80x. 11. Globigerinoides trilobus (Reuss, 1850), spiral view. Sample 121-757B-11H-2, 110-115 cm, 50×. 12, 13. Globoquadrina praedehiscens Blow and Banner, 1962, Sample 121-754A-12H-CC. Fig. 12. Umbilical view of specimen with abortive, bullalike final chamber, $60 \times$. Fig. 13. Spiral view, 70×. 14-17. Acarinina coalingensis (Cushman and Hanna, 1927) group. Fig. 14. Specimen with relatively small final chamber, Sample 121-752A$21 \mathrm{X}-1,110-115 \mathrm{~cm}, 110 \times$. Fig. 15. Specimen with relatively large final chamber, Sample $121-752 \mathrm{~A}-14 \mathrm{X}-3,110-115 \mathrm{~cm}, 110 \mathrm{x}$. Fig. 16 . Compact specimen with angular final chamber (A. nitida (Martin, 1943)), Sample 121-757B-17H-CC, 80x. Fig. 17. Side view of specimen with rugose wall, Sample 121-758A-28X-2, $115-120 \mathrm{~cm}, 80 \times$. 18-20. Very rugose specimens of the A. coalingensis group. Figs. 18, 20. Sample 121-753A-6H-3, 110-115 cm, 130×, Fig. 19. Sample 121-758A-28X-2, 115-120 cm, 90x. 


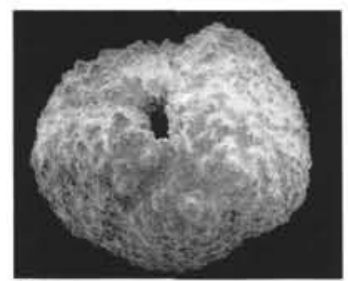

1

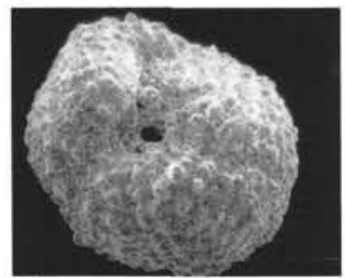

5

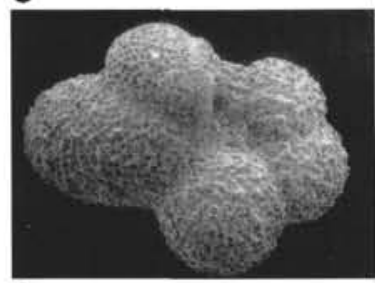

9

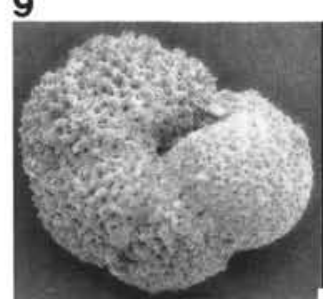

13

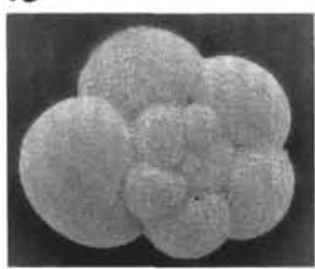

17

14

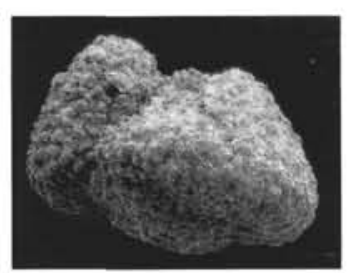

2

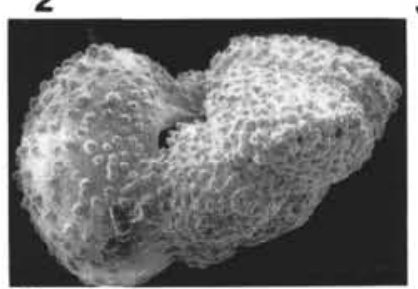

6

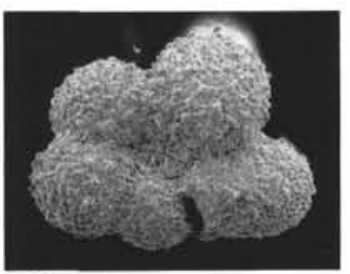

10
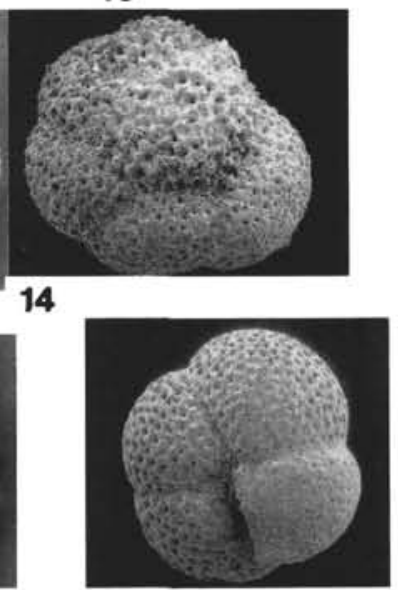

18

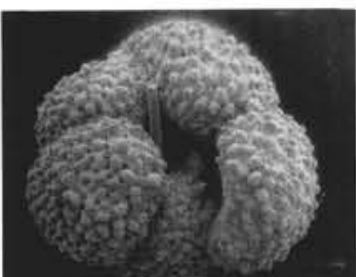

3

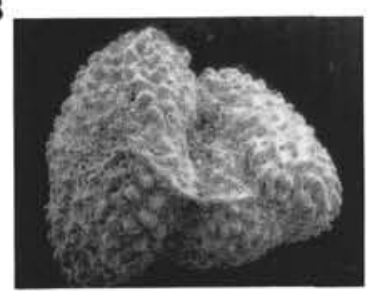

7

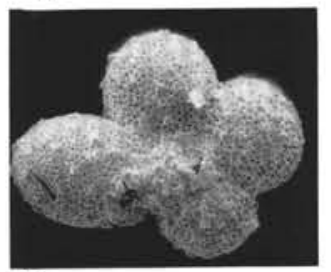

11

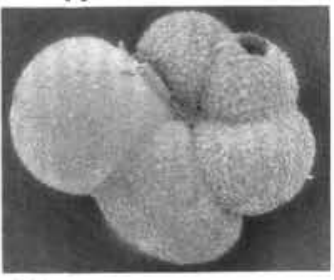

15

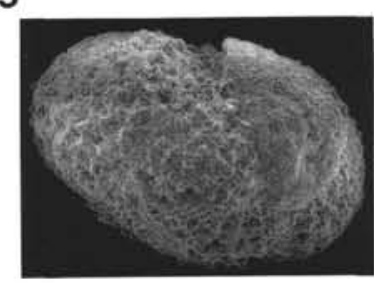

19

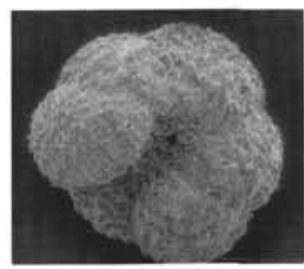

4

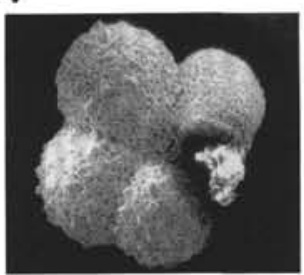

8

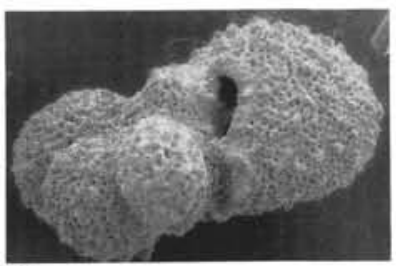

12

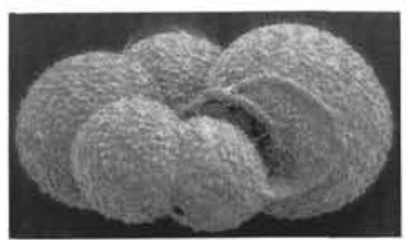

16

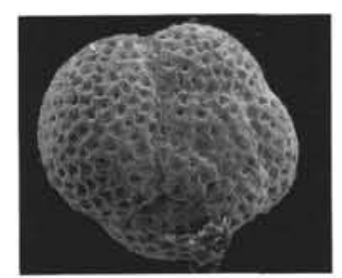

20

Plate 4. 1, 2. Acarinina densa (Cushman 1925b). Fig. 1. Umbilical view, Sample 121-757B-20X-CC, 80x. Fig. 2. Side view, Sample 121-757B-17H-CC, 80x. 3. Acarinina pentacamerata (Subbotina, 1947), specimen showing affinity with the A. coalingensis group, Sample $121-752 \mathrm{~A}-21 \mathrm{X}-1,110-115 \mathrm{~cm}, 70 \times .4$. Acarinina gravelli (Brönnimann, 1952a), Sample 121-752A-27X-CC,90x. 5. Acarinina sp., intermediate between A. densa and A.pentacamerata Sample 121-752A-22X-CC, 100x. 6. Acarinina sp. Small, planoconvex specimen with inflated final chamber, considered as belonging to the A. coalingensis group, to which it is linked by intermediate forms. Sample 121-752A-21X-1, 110-115 cm, 140x. Fig. 7. Acarinina wilcoxensis (Cushman and Ponton, 1932a), Sample 121-752A-13X-3, 110-115 $\mathrm{cm}, 90 \times .8-12$. Aff. Clavatorella nicobarensis Srinivasan and Kennett, 1976. Fig. 8. Small specimen with small final chamber, Sample 121-758A-21X-2, 110-115 $\mathrm{cm}, 120 \times$. Fig. 9. Large specimen with small final chamber, Sample 121-758A-21X-1, 110-115 cm, 100×. Fig. 10. Large specimen with large final chamber. Note almost equatorial aperture. Sample 121-758A-21X-1, 110-115 cm, 100x. Fig. 11. Small specimen with large final chamber, Sample 121-758A-21X-1, 110-115 $\mathrm{cm}, 110 \times$. Fig. 12. Side view, Sample 121-758A-21X-1, 110-115 cm, 120x.13, 14. Fohsella kugleri (Bolli, 1957a), Sample 121-757B-11H-CC. Fig. 13. Umbilical view, 140x. Fig. 14. Spiral view, 160x. 15-17. "Globorotalia" postcretacea (Myatliuk, 1950).Sample 121-756C-5H-CC. Figs. 15 and 17. 120x. Fig. 16. 160x. 18-20. Globorotaloides suteri Bolli, 1957a. Fig. 18. Sample 121-758A-22X-CC, 120x. Figs. 19, 20. Sample 121-758A-25X-1, 110-115 cm, 140x. 


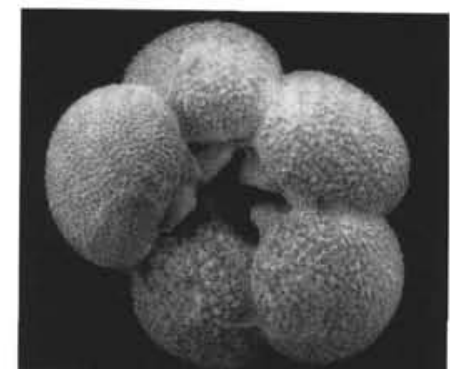

1

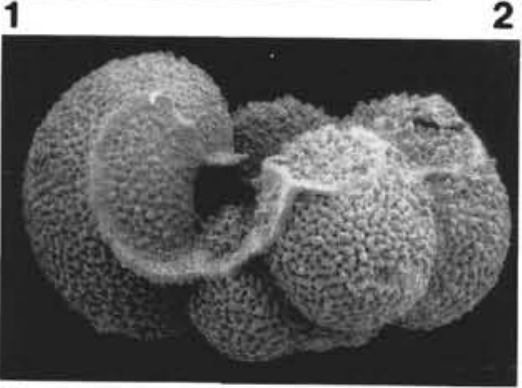

4

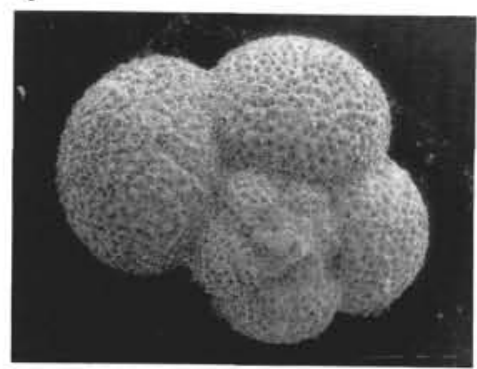

7

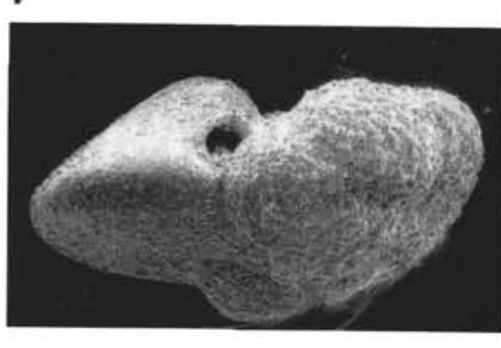

2

8
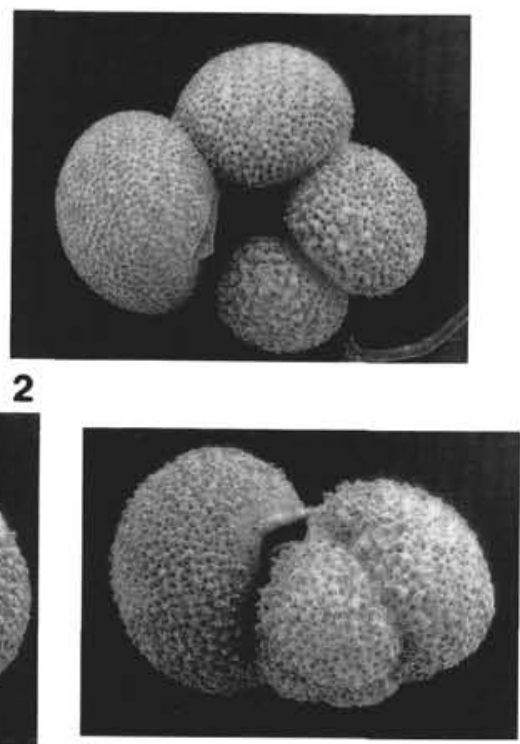

5
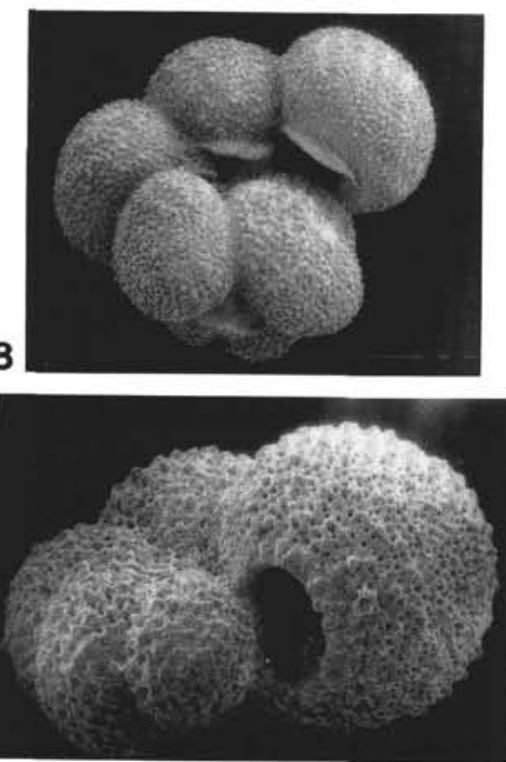

11

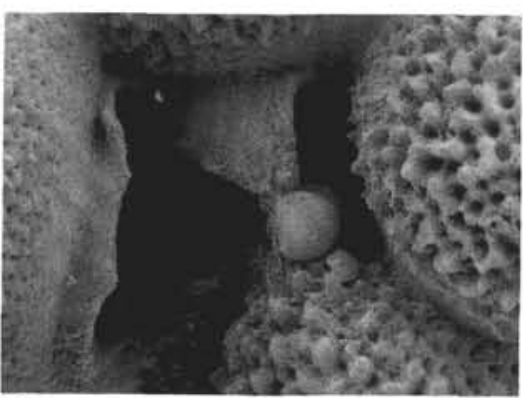

3

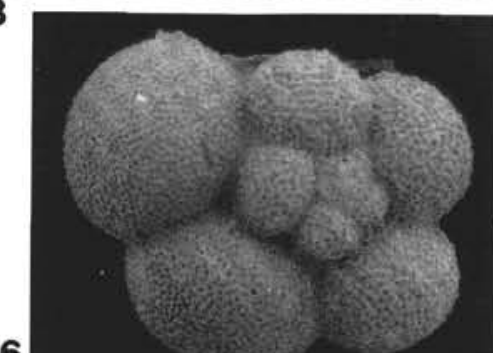

6

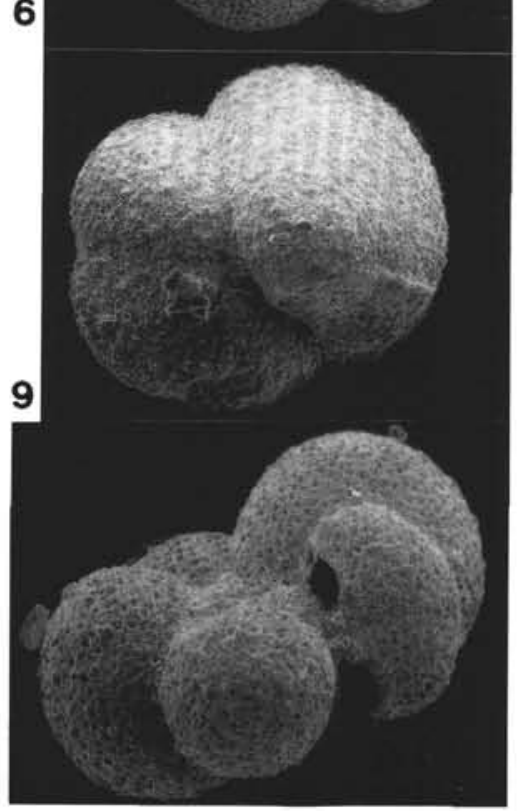

12

Plate 5. 1-8. Morozovella variospira (Belford, 1984). Fig. 1. Large specimen with five chambers in the final whorl and well-developed apertural teeth. Sample 121-758A-30X-3, 115-120 cm, 50x. Fig. 2. Small specimen with four chambers in the final whorl and poorly developed apertural teeth. Sample 121-758A-30X-1, $115-120 \mathrm{~cm}, 60 \times$. Fig. 3. Detail of the umbilicus of a medium-sized specimen. Apertural tooth of final chamber broken. Sample 121-758A-30X-1, 115-120 cm, 150x. Fig. 4. Side view of a large specimen with four and a half chambers in the final whorl. Sample 121-758A-30X-CC, 60x. Fig. 5. Side view of a small specimen with four chambers in the final whorl. Sample 121-758A-31X-1, 115-120 cm, 75×. Fig. 6. Spiral view of a large specimen with five chambers in the final whorl, the final chamber is broken. Sample 121-758A-30X-CC, 50x. Fig. 7. Spiral view of a small specimen, Sample 121-758A-30X-CC, 75x. Fig. 8. Aberrant, high-trochospiral specimen. Note poorly developed apertural teeth. Sample 121-758A-30X-CC, 50X. 9, 10. Planorotalites australiformis (Jenkins, 1966), Sample 121-752A-13X-3, 110-115 cm. Fig. 9. 125×. Fig. 10. 150x. 11, 12. Aff. Protentella prolixa Lipps, 1964, Sample 121-758A-21X-1, 128-133 cm, 150x. Fig. 11. Typical specimen. Fig. 12. Specimen with aberrant final chamber with two apertures. 